\title{
Can EU Judicial Intervention Increase Polity Scepticism? Quasi-Experimental Evidence from Spain
}

\author{
Stuart J. Turnbull-Dugarte*\& Daniel Devine ${ }^{\dagger}$
}

\begin{abstract}
The mantra of "take back control" has become a staple of eurosceptics across the European Union. At the centre of the slogan's message is a call to arms against the (perceived) challenge that EU membership represents for national sovereignty. In this paper, we theorise that supranational decisions taken by the European Court of Justice can increase 'polity scepticism' - increased opposition to the EU and decreased satisfaction with national democracy - by cueing citizens regarding the effects of EU integration on the perception of diluted sovereignty. Empirically, we leverage quasi-experimental evidence to support our theory, establishing that ECJ rulings have a significant causal effect on euroscepticism and dissatisfaction with democracy. The implications of our findings suggest that EU institutions seeking to ensure compliance with the rule of law and EU norms should proceed with caution. Interventionist action may backfire by increasing scrutiny of the EU's legitimacy and undermining polity support.
\end{abstract}

Keywords: Euroscepticism, European Court of Justice, Spain, quasi-experiment, Junqueras, sovereignty

Pre-print (16/02/2021) of version to be published in the Journal of European Public Policy

*University of Southampton. Email: S. Turnbull-Dugarte@Soton. ac.uk

†St Hilda's College, University of Oxford. Email: Daniel. Devine@St-Hildas .ox.ac.uk 


\section{Introduction}

The institutions of the European Union (EU) are faced with a dilemma. The EU's supranational institutions are required to engage in domestic member state politics in order to safeguard the polity's fundamental values, ensure compliance with EU regulations and law, and to bolster the economic security of the community. The interventionist actions needed to facilitate these functions, however, are increasingly required in a context where external action from a non-state actor is perceived as inimical to the interests of national state sovereignty. Dissenters and eurosceptic politicians have established themselves by placing a focus on populist nationalist sovereigntism (Baldini et al. 2020), promoting calls to "take back control" from the EU and portraying the EU as an "external oppressor" that "liquidates" state sovereignty and democratic freedom (Csehi and Zgut 2020). In a climate where EU institutions are "under attack" (Bressanelli et al. 2020), EU intervention within member states comes with high risks. External action allows parties and politicians to politicise the questions of sovereignty and tap into voters' nostalgic image of the autonomous functioning of sovereign democracy, traditionally demarcated by the boundaries of the nation state (Weale 2016).

The theoretical literature echoes these concerns. It suggests that the growing influence of actors beyond the domestic sphere leads to a hollowing out of national-level democratic processes (Mair 2013), leading to a 'democratic void', and the establishment of an apolitical and democratically unresponsive technocratic order (Sánchez-Cuenca 2017). This, it is argued, leads to polity-scepticism: not just scepticism regarding European integration, but also of the domestic system of governance, indicated through a loss of democratic satisfaction, political trust, and an increase in euroscepticism (Mair 2013; Scharpf 1999). At the core of this is the assumption that individuals care about domestic 'sovereignty' and national self-determination. Action taken by external supranational actors, whilst providing net positive gains in terms of economic performance 
and compliance with democratic norms ${ }^{1}$, can be viewed as imperialist and threatening to the proper and legitimate autonomous functioning of the democratic state (Csehi and Zgut 2020). When EU-solicited policy changes at odds with those desired by domestic publics are implemented by member states, doubts emerge regarding the legitimacy of these policies and the ability of domestic political actors be responsive rather than responsible (Armingeon et al. 2016; Borriello and Brack 2019; Mair 2009). The (perceived) threat to sovereignty is an important thread that runs through scepticism against the European project. Whilst left-wing and right-wing eurosceptics are divided on the ideological motivations of their opposition to European integration, the common denominator is the concern that integration undermines autonomy of the member state and the popular sovereignty of the people to be governed solely by accountable institutions (Halikiopoulou et al. 2012).

Despite this theoretical attention, the empirical evidence that explores the effect of explicit intervention in domestic politics from EU actors on individual political attitudes remains largely limited to assessments of EU-level action taken during the Eurozone crisis (e.g Schraff and Schimmelfennig 2019). The literature is, as a result, mostly focused on the European Central Bank and the European Commission given their central interventionist actions during the Eurozone crisis, whilst little empirical work has focused on other EU institutions or agencies. Outside of the Eurozone crisis context, some research suggests that interventions from European actors to negate anti-democratic actions of domestic elites actually bolster support for the domestic incumbent and increase euroscepticism (Schlipphak and Treib 2017).

In this paper we contribute to this vein of literature by focusing on actions taken by the European Court of Justice (ECJ) in 2019. ECJ decisions are a core avenue via which sovereignty transfers can occur (Saurugger and Fontan 2019). We analyse the effect of an ECJ ruling on Spanish domestic politics, arguing that ECJ actions shape citizens' beliefs about both the workings of national democracy and their preferences for greater

\footnotetext{
${ }^{1}$ This is also echoed by scholars that contrast the benefit the EU provides for output legitimacy at the detriment of input legitimacy (e.g Schmidt 2013; Scharpf 2013)
} 
supranational integration. As Blauberger and Schmidt (2017) highlight, the attention given to the impact of decisions from the ECJ from a political science perspective is extremely limited. Whilst a body of work assesses the legislative consequences of the court's jurisprudence (e.g Martinsen 2015), as of yet there is no empirical assessment of how the supranational court's decisions influence political support. We fill this gap and contribute to the understanding of the relationship between the EU and its member states by using a quasi-experimental research design to test the causal impact of an ECJ ruling on polity scepticism in Spain. The ECJ's verdict in the salient case of the Catalan seperatist, Oriol Junqueras, was delivered during the Spanish fieldwork of the European Social Survey (ESS). The naturally exogenous exposure to this widely reported and politically salient news allows us to estimate the causal effect of ECJ rulings on individual-level euroscepticisim and satisfaction with national democracy. We argue that the EU's judicial intervention in Spain led to a sizeable and significant increase in popular euroscepticism and a decline in democratic satisfaction, though our evidence is weaker for the latter. On average, individuals in the treatment group exposed to the ECJ verdict became 13\% more eurosceptic than those who were not exposed to the ruling. In the case of attitudes towards the performance of democracy, the EU court's decision increased dissatisfaction with democracy by $6 \%$ relative to those interviewed before the decision.

The contribution of our analyses seeks to fill two important gaps within the literature. Our first contribution is theoretical. We develop our understanding of the role that the ECJ plays in domestic politics by posing a model in which ECJ rulings represent an important information cue that signals the extent of the EU's influence over domestic politics in the eyes of member state citizens. An important distinction that we seek to make is that ECJ decisions not only serve to bring about future changes in EU integration or europeanisation (Stone Sweet 2010), but also serve as signals to voters regarding the reach of EU integration. We theorise that ECJ rulings act as a heuristic that informs voters of the consequential impact on state sovereignty of EU integration. Our second contribution is empirical. Whilst the understanding of the individual- 
level determinants of democratic satisfaction (Ferrín and Kriesi 2016) and support for EU integration has been extensively assessed (Hobolt and De Vries 2016), few empirical contributions have sought to identify and isolate the causal impact of the consequences of European governance on these attitudes. A new body of experimental work is emerging to remedy this gap: Foos and Bischof (2019), for example, leverage a quasi-experimental design to show that exposure to eurosceptic media reporting has a sizeable casual effect on increasing opposition to EU integration in the UK; and De Vries (2018) demonstrates that exposure to domestic corruption scandals can increase the relative support for the EU in comparison to the domestic government. Moving beyond the impact of these domestically-induced effects, we add to this work by presenting the findings of a quasi-experiment in which we show that EU-level action can cause an increase in polity scepticism, with citizens becoming both more eurosceptic and less satisfied with democracy in general.

Our findings have important implications for understanding both euroscepticism and democratic satisfaction within the EU's multilevel governance framework. Our results are consistent with previous research using observational designs that show that EUlevel action can increase euroscepticism and decrease domestic democratic satisfaction (Schlipphak and Treib 2017; Armingeon et al. 2016). These findings pose a paradox for European decision-makers. Whilst an explicit requirement of EU membership is to abide by European law and its fundamental values, evidence suggests that enforcing this may result in a backlash both against the EU and against the working of national democracy. The implication is that European actors must be very careful when devising interventions in defence of its key principles; ill-conceived interventions may end up undermining the very purpose they serve. 


\section{Integration, intervention \& the sovereignty question}

European integration is, at its core, a transfer of sovereignty from the national to European level. This shifting of competences from national to European layers of governance, combined with a lack of vibrant democratic contestation at the supranational level, has been argued within the theoretical literature to lead to the 'hollowing out' of domestic processes that are seen as legitimate (Mair 2013; Scharpf 1999) and the reduction of sovereignty to a "diminished form of statehood" (Bickerton 2012). Mair (2013) argued that this reduced scope for political contestation could have the effect of kindling a rise in polity-scepticism: not just a rebellion against European governance perceived as over-reaching, but of domestic democratic governance too. In short, the establishment of politics without policy in the national arena, and policy without politics in the supranational arena (Schmidt 2006) can leave citizens both opposed to integration and discontented with the functioning of democracy at home.

Whilst the theoretical literature that makes this claim is well established, the empirical examination of these claims largely focus on the Eurozone crisis and its aftermath. This is unsurprising considering that this period is one in which international actors were explicitly involved in salient domestic policy decisions in Southern Europe and Ireland which were imposed largely against the wishes of the public. Armingeon et al. (2016), for instance, find that those countries that experienced economic intervention became less satisfied with democracy at the European and domestic levels. There is strong evidence that autonomy over decision-making also played a role in the formation of support for domestic institutions (e.g Armingeon and Guthmann 2014), though this has been contested (Devine 2019). These authors argue that one of the key drivers of the decline in democratic satisfaction and political trust was the perceived "democratic void" (Sánchez-Cuenca 2017) created by the intervention of the EU's economic and financial institutions (Troika) into domestic politics, which limited the ability of state governments to govern legitimately in a way that reflected the preferences of their citizens. In other words, EU intervention, at least in the case of the Eurozone crisis, 
exacerbated the conflict between responsibility and responsiveness by strong-arming the intervened-in states to adopt policy measures that were explicitly rejected by the voters.

Outside of the context of the Eurozone crisis, Schlipphak and Treib (2017) have shown how even limited interventions by the EU in Austria and Hungary to prevent democratic backsliding, an increasingly important concern among member states (Kelemen 2017), correlates with increased euroscepticism rather than shaming the domestic government for democratic failures. By framing the interventions as an attack on democratic self-governance, domestic elites turned the "blame game on Brussels". This argument is consistent with the perception of the EU as a vehicle of foreign influence amongst post-communist nations during EU accession. Eurosceptic entrepreneurs on both the left and the right rely on the rhetorical appeals to the threat of EU integration to national sovereignty and legitimate democratic decision-making processes to rally their supporters (Halikiopoulou et al. 2012). Autocrats from Hungary and Poland have doubled down on the anti-EU tenor of their messaging by explicitly equating EU intervention and conditionality with imperialism and state oppression (Csehi and Zgut 2020)

Observationally, the literature demonstrates that citizens can update their preferences on the EU when it is perceived as 'meddling' (Schlipphak and Treib 2017). The literature specifically centred on the consequences of EU intervention provide robust empirical findings, but also has limitations. First, the bulk of the empirical research focuses on the Eurozone crisis period and the specific instances of intervention via the Commission, ECB and IMF (Troika) as part of the financial bailout program, and therefore it is unclear whether the conclusions can be extended beyond that unique period in time and set of actors. Second, all studies to our knowledge either rely on aggregate survey data or observational studies at the individual level which cannot exclude the possibility of reverse causality, some confounding factor, or different dynamics at the aggregate versus individual levels. Moreover, these interventions are conducted dur- 
ing considerable economic turmoil, meaning it cannot be entirely excluded that the change in political attitudes is attributable to the economic conditions which preceded the interventions (Foster and Frieden 2017). We aim to fill these gaps within the literature by focusing on a case in 2019, over a decade after the first Troika intervention, by a different (non-economic) actor.

\subsection{The ECJ as vehicle of intervention \& threat to sovereignty}

Our specific case of EU-level action in the domestic sphere is the ECJ. A wide body of literature establishes the twofold constraining nature of the ECJ on state sovereignty. The European court acts as an "independent motor" of European integration (Blauberger and Schmidt 2017), in a manner that increases the competences of the EU over areas of policy regulation not explicitly conceded to the EU via the Treaties (Pollack 2003; Martinsen 2009, 2015). The EU-wide and precedent-establishing nature of the Court's decisions (Blauberger and Schmidt 2017) have, at times, fuelled criticism against the ECJ for being an undemocratic judicial advocate of "ever closer union" (see, for example, Dawson et al. (2013)). A number of empirical studies have sought to take stock of the claims of judicial activism within the court by assessing the potential for bias in the outcomes of its rulings. The ECJ has a clear pro-integration bias in that its decisions tend to result in the expansion of its own discretionary powers (Pollack 2003) and its jurisprudence can lead to "integration through law" (Stone Sweet 2010). Increased integration essentially means more powers for the EU institutions and less autonomous national decision-making discretion for member states.

In addition to the court's ability to upload state autonomy to the EU, the court also drives the downloading of EU-established norms into the domestic member state level. For example, ECJ rulings have established the ability of EU citizens exercising their freedom of movement rights to gain equal access to the welfare state provision, including non-contributory welfare, offered to state nationals and has expanded 
the eligibility of these provisions to include EU citizens' family members from non-EU countries (Blauberger and Schmidt 2014). Given a political climate where the interconnected nature of EU integration and immigration is becoming increasingly salient for electorates and political parties (Abou-Chadi and Wagner 2020), the court's decision has the potential to fuel populist rhetoric regarding the need to "take back control" from the EU (Armstrong 2017).

As the European court has begun litigating in areas which have observable political consequences, the permissive support traditionally enjoyed by the EU judiciary (Kelemen 2012) has also began to dissipate (Hofmann 2018; Blauberger and Schmidt 2014; Werner 2016). EU judicial intervention in more sensitive and domestically salient areas has kindled public awareness of the activity of the court (Kelemen 2016) as well as a rise in public backlash against some of its rulings (Dawson et al. 2013). Because these rulings come from an external supranational state actor, public perceptions of the court's decisions will likely be highly influential in determining individuals' attitudes towards the supranational union as these can be viewed as "foreign impositions on national communities" (Pollack 2018).

Sovereignty, much like political responsibility (Kumlin 2011), can be viewed in the eyes of citizens as zero-sum. ${ }^{2}$ If the EU is expanding its sovereignty by gaining more competences via ECJ jurisprudence, this necessitates that the perception of national sovereignty is being diluted. On the one hand the court can dilute member state sovereignty by ascertaining competences that were not explicitly laid out in the treaties. On the other hand the court can constrain sovereignty by overriding domestic policy or judicial decisions that it rules to be in violation with EU law. When court decisions rule in opposition to member states, scepticism based on the legitimacy of supranational oversight is likely to emerge (Larsson and Naurin 2019). Note that this argu-

\footnotetext{
${ }^{2}$ This is not to say that sovereignty is itself zero-sum. In fact the collective aggregation of state problem-solving capacity for policy concerns that cross the imagined border of the state (e.g. climate change or Covid-19), and in increased negotiating power of states operating as a collective body with third parties is also argued to provide the state with more sovereignty than could be obtained via the summation of states' individual sovereignty.
} 
ment implies a fundamental scope condition: this only applies to ECJ decisions which run against domestic policy or public opinion, since these are the only ones that would be considered 'constraining' of, or 'meddling' in, domestic politics.

Nonetheless, we theorise that decisions from the court can have an important effect on citizens' views. Our argument is that ECJ rulings serve as an informational heuristic that catalyses an increased awareness and understanding among citizens regarding the sovereignty-diluting effects of EU integration that may have already taken place. If ECJ rulings, perceived as external interference (Pollack 2018) in domestically salient and politically sensitive issues can lead to increased support for nationalist sovereigntism and reduced support for supranational solidarity (Blauberger and Schmidt 2014), we posit that this will also affect polity support. Reduced sovereignty, perceived or real, not only makes citizens unhappy with the constrainer (the EU) but also less satisfied with the functioning of national democracy in general (Mair 2013; Scharpf 1999). Our primary hypotheses therefore are twofold:

H1: ECJ outcomes that rule against national decisions will increase euroscepticism

H2: ECJ outcomes that rule against national decisions will increase dissatisfaction with democracy

Of course increased opposition to the EU and a rise in dissatisfaction with democracy following ECJ decisions may simply be indicative of 'losers' discontent'. Work on responsibility attribution, particularly between levels of governance in the European Union, show that how citizens perceive European action is shaped by factors such as partisanship and positions on European integration (e.g Hobolt and De Vries 2016). As such, we may expect heterogeneous effects depending on a citizen's prior views. Should a rise in polity scepticism be the product of 'loser's discontent', we would expect partisan rationality to moderate the effect of the decision. In short, individuals who identify in a way that makes them more likely to disagree with a court decision 
would be expected to respond asymmetrically to the court outcome in comparison to the wider population. We test for this possibility with the following hypothesis:

H3: Effect of intervention will be conditioned by partisan alignment with the judicial outcome

\section{Research Design}

In order to test our theoretical expectations, we use the quasi-experimental setting presented by the announcement of the salient and highly politicised ECJ ruling in Spain in December 2019. Our approach follows the "unexpected event during survey" (UEDS) design (Muñoz et al. 2020), which is an increasingly applied technique for the identification of causal effects of important and unexpected events on political outcomes. ${ }^{3}$ The announcement of the ECJ's ruling in the Junqueras case was published on December 19th during the period of fieldwork for wave 9 of the ESS which took place between November 8th and January 27th. The unexpected outcome of the ECJ's decision provides us with a quasi-experiment with (naturally) exogenous random assignment of exposure to the ECJ decision. First, we describe the case and show its suitability for testing our hypotheses. We then describe the data and detail our empirical approach.

\subsection{Case: Junqueras vs Kingdom of Spain (E VOX)}

Our study focuses on the legal proceedings in the criminal case against the former Vice President of the Catalan government, Oriol Junqueras, which reached the ECJ ${ }^{4}$ after an initial criminal conviction was sentenced in the Spanish Supreme Court.

The legal battle between Junqueras and the Spanish state was the result of the continuous and highly politicised territorial conflict taking place in Spain. In October 2017, the

\footnotetext{
${ }^{3}$ See, for example Bol et al. (2020)'s study on the effect of Covid-19 lockdowns on political support; or Solaz et al. (2019)'s assessment of government corruption scandals on support for the incumbent.

${ }^{4}$ Case number C-502/19. Available at EUR-Lex Case Law repository: https : //eur-lex . europa. eu/ legal-content/EN/TXT/?uri=CELEX: 62019CJ0502
} 
Catalan Government, led by a coalition of separatist parties, held an unauthorised referendum on Catalan independence. The proponents of independence continued with the referendum despite a previous ruling by the Spanish Constitutional Court that the referendum could not take place and that the devolved government in Catalonia did not possess the legal competences to hold the plebiscite. The decision to hold the referendum on October 1st without the consent of the national government and in direct opposition to the prohibition of Spain's Constitutional Court had a number of seismic effects. One of the most significant direct responses was the intervention by the national police force which used what many international media outlets described as extreme force to stop people from taking part in the polling event. More substantially, after the Catalan separatists unilaterally declared independence from Spain on October 27th, the Spanish Prime Minister, the centre-right's Mariano Rajoy, invoked Article 155 of the Constitution which allowed him to force the dismissal of the regional government, the dissolution of the Catalan legislature, and to impose direct rule from the central government in Madrid. Indirectly, the knock-on effects of these events have contributed to an increasing level of polarisation between Spanish voters on the issue of nationalism and territorial politics (Simón 2020), as well as the emergent success of Spain's new populist and radical right-wing party, VOX (Turnbull-Dugarte 2019).

Judicial proceedings were brought forward against twelve former members of the Catalan government, amongst whom were Junqueras ${ }^{5}$, on charges of rebellion, sedition and misuse of public funds. The trial, which lasted for five months (February 12th - June 12th 2019), was aired live on Spanish television and heavily reported on at the time, included prosecutors from both the state as well as Spain's new radical rightwing party, VOX, who officially joined the suit as a private prosecutor in an attempt to monopolise on the political opportunity the judicial proceedings represented for the new party (Turnbull-Dugarte et al. 2020).

The Spanish Supreme Court's verdict, announced on October 14th, sentenced Jun-

\footnotetext{
${ }^{5}$ Junqueras became the primary face of the judicial proceedings given that the former Catalan president, Carles Puigdemont, successfully fled to Belgium to avoid prosecution.
} 
queras to thirteen years in prison for sedition and misuse of public funds. ${ }^{6}$ Upon sentencing, Junqueras' legal representatives appealed against the verdict of the Spanish Supreme Court and filed a motion with the ECJ. Their claim was that, given Junqueras had been elected as an MEP as of May 26th 2019, he should have been allowed to take up his seat in the European Parliament and enjoy the judicial immunity that comes with it. Two months later on December 19th, the ECJ pronounced its unanimous verdict in support of Junqueras, proclaiming that from the moment the results of the EP election were announced, Junqueras had enjoyed the judicial immunity he had a right to as an MEP, bringing his criminal conviction from the Spanish Supreme Court into question.

Many commentators, particularly those critical of the independence movement, were quick to communicate their discontent with the ECJ ruling. The leader of the Catalan branch of the centre-right People's Party protested that the decision in favour of Junqueras' immunity may buttress support for Spain's exit of the EU. VOX's leader, Santiago Abascal, tweeted that the outcome was a "new humiliation for Spain" whilst other party surrogates such as VOX's Congressional spokesman, Espinosa de los Monteros, insisted that the ECJ's decision was an "insult against Spain" and an "attack on our [Spanish] sovereignty". Political punditry on the ECJ ruling became the prime time news story of the day - by 6pm, more than 209,300 tweets were posted in Spain mentioning "Junqueras" and, at the same time "Spexit" was the number one trending topic on Spanish twitter. ${ }^{7}$

The ECJ's ruling in the Junqueras trial presents us with a notable case where EU-level actions can have a sizeable impact on salient political activity taking place within the domestic sphere. The judicial outcome exercised by the ECJ is an important example

\footnotetext{
${ }^{6} \mathrm{~A}$ quasi-experimental analysis of this domestic decision demonstrates that Spain'ss right-wing voters were contented by outcome, becoming significantly more satisfied with democracy as a result (see appendix file for demonstration).

${ }^{7}$ By the same time point, 41,700 tweets from Spain were shared with a reference to "Spexit" and 95,800 tweets made reference to the "TJUE" (Spanish acronym for the ECJ) [Tribunal de Justica de la Unión Europea]. The three terms were the top three trending topics on Twitter at that time (Data taken from the Twitter API).
} 
against which our theoretical hypotheses can be tested. In the following section, we detail the empirical approach adopted to assess whether the ECJ's ruling caused Spanish citizens to become more dissatisfied with democracy or sceptical of EU integration.

\subsection{Analytical approach}

A random selection of ESS respondents were interviewed before the announcement (Control group) and a random selection were interviewed post-hoc (Treatment group). The ESS provides a total sample of 1,668 survey respondents for Spain, of which 29\% $(\mathrm{N}=481)$ fall in the treatment group and $71 \%(\mathrm{~N}=1,187)$ in control. The distribution of respondents by treatment assignment and the mean pre-treatment covariate values for each group are summarised in Figure 1. Comparing the distribution of pre-treatment covariates (age, gender, income, education and left-right ideological position) and party voice choice demonstrates no significant imbalances between the two treatment groups (see Table A1 and A3.) for the full survey period with the exception of age. ${ }^{8}$ There is also no significant relationship between missing values on either of our outcome measures and treatment assignment).

The main explanatory variable of interest is a simple dichotomous variable that indicates those surveyed before and after the court's ruling. Our estimand of interest is the intent-to-treat (ITT) ${ }^{9}$ effect of treatment assignment on our outcomes and is indicative of the effect of assignment assuming compliance with receipt of the treatment.

We have two main dependent variables: euroscepticism and democratic satisfaction. Attitudes towards euroscepticism are multidimensional (Boomgaarden et al. 2011; Hobolt and De Vries 2016) and include preferences shaped by diffuse (regime) scepticism and specific (policy) scepticism (De Vries 2018). We conceptualise euroscepticism

\footnotetext{
${ }^{8}$ Balance tests across different bandwidth windows and using a wider battery of pre-treatment covariates are also reported in the appendix

${ }^{9}$ Summarised as: $\operatorname{ITT}_{Y}=\frac{1}{N} \sum_{i=1}^{N} Y_{i}(z=1)-\frac{1}{N} \sum_{i=1}^{N} Y_{i}(z=0)$

where $Y_{i}(z=1)$ is the potential outcome for individual $i$ under treatment assignment and $Y_{i}(z=0)$ is the potential outcome for $i$ under assignment to control.
} 


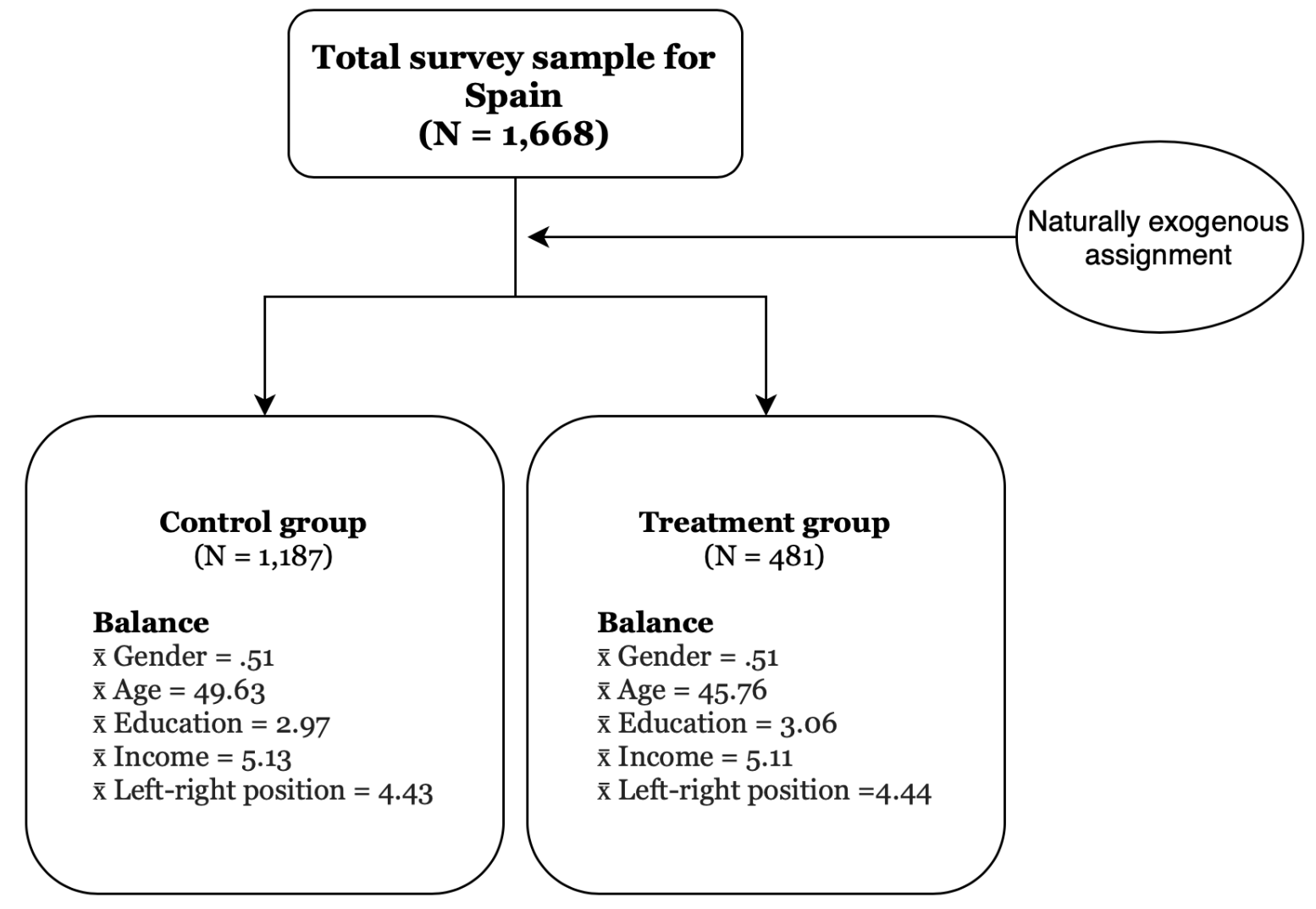

Figure 1: Treatment assignment and covariate balance

as the former. As such, we use the following survey item in the ESS: "Now thinking about the European Union, some say European unification should go further. Others say it has already gone too far. Using this card, what number on the scale best describes your position?" Individuals can respond on an eleven-point scale from 0 "Unification already gone to far" to 10 "Unification go further". We reverse this order so that higher values indicate increased euroscepticism. We conceptualise democratic dissatisfaction as a similarly diffuse attitude which captures perceptions of the general working of democracy. Whilst this is of course multidimensional and individuals will reach their judgements differently, there is also evidence that it is similarly understood across Europe (Ferrín and Kriesi 2016). We measure this by taking responses to the survey question: "How satisfied are you with the way democracy works in [country]?", satisfaction with democracy is measured from 0 "Extremely dissatisfied" to 10 "Extremely satisfied". As in the case of euroscepticism, we reverse this order with higher values indicating greater levels of dissatisfaction ${ }^{10}$.

\footnotetext{
${ }^{10}$ Wave 9 of the ESS does not include alternative measures such as satisfaction with EU democracy.
} 
The empirical model can be summarised in the basic linear regression estimation:

$$
\begin{gathered}
Y_{i}=\alpha+\beta_{1} \text { Treatment }_{i}+\epsilon_{i} \\
Y_{i}=\alpha+\beta_{1} \text { Treatment }_{i}+\beta_{2} X_{i}+\epsilon_{i}
\end{gathered}
$$

The independent ITT of the ECJ ruling is captured in $\beta_{1}$ Treatment $_{i}$ (model 1), whilst $\beta_{1}$ Treatment $_{i}$ (model 2 ) reports the covariate-adjusted ITT ${ }^{11}$ after considering the potential effect of a vector of pre-treatment covariates, $\beta_{2} X_{i}$. We use the same covariates used for balance across treatment assignment (see Figure 1). Alternative models with the inclusion of regional fixed effects (see appendix Table A7) replicate the main findings. ${ }^{12}$

Before presenting the main results, we seek to demonstrate the validity of our identification strategy. We demonstrate that the ECJ's ruling was an unexpected event that citizens were very likely to be aware of when it occurred. Figure 2 shows Google Trends data for the thirty-one days in December in 2019 and shows the very high levels of public interest given to the ruling. It reports the popularity of online searches for either "Junqueras" or "European Court" (Tribunal Europea in original) over the thirtyone day period. A Google Trends score of 100 indicates the highest level of popularity for the search term from the country and period assessed. A value of 20 would indicate that the popularity of the term was at $1 / 5$ of the maximum popularity observed. On the day of the ECJ's ruling - December 19th - we observe a sizeable spike and peak in the level of public interest in both of the search terms we consider. The interest observed in the Google Trends data, as well as that of social media activity discussed

\footnotetext{
${ }^{11}$ Following the recommendations of Muñoz et al. (2020), covariate-adjusted ITTs are also estimated via matching techniques. The output of these matching models (see appendix Figure A9) display significantly consistent effects. We model direct matches on gender and use mahalanobis distance for the other covariates.

${ }^{12}$ All models apply the sampling design weights provided by the ESS and rely on the imputation of missing covariate values in the covariate-adjusted models. Iterations without sampling weights or imputation are reported in the appendix and do not condition our results.
} 
above, is also mirrored by reporting in the Spanish press. The front-page headlines on the first day following the ruling in both the left-leaning El País and the right-leaning $A B C$, focused on the ECJ's decision (see appendix Figure A26 and A27). There is, therefore, strong evidence that points towards the treatment effect of the ECJ's ruling being a salient feature amongst both the general population as well as the mainstream media environment, so we can be confident that our treatment variable is capturing the effects of the shock exposure to the news.

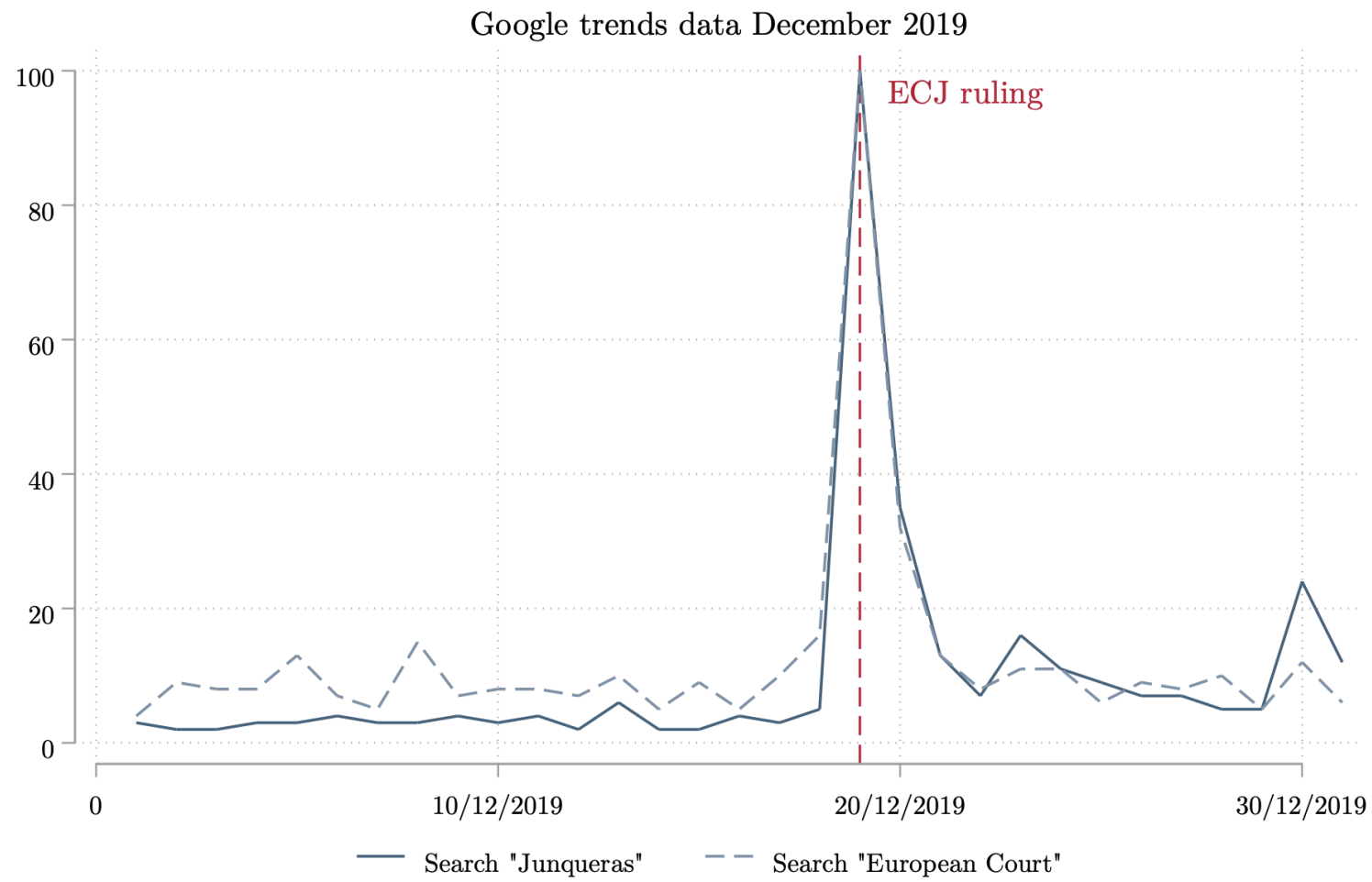

Figure 2: Popular salience of treatment event

\section{Results}

The causal impact of the ECJ's ruling on euroscepticism is reported in Figure 3 (full regression output in Table A4 and A5). The left-hand panel of the figure reports the ITT effect (independent and covariate adjusted) on euroscepticism. The ITT here can be interpreted as the the change in euroscepticism $(0-10)$ caused by exposure to the 
ECJ ruling. The ITT is both significant and substantive. The ECJ's ruling increased euroscepticism by .48 (half a point on an eleven-point scale). This is a noteworthy causal effect as it signals an increase of $13 \%$ relative to the control group or $19 \%$ of a standard deviation. Coefficients with and without covariates are near-identical.

The right-hand panel displays the percentage-point change in the probability of being a eurosceptic caused by the ECJ ruling. Looking first at the unadjusted ITT, exposure to the ECJ ruling led those in the treatment group to have a probability of being eurosceptic 6 percentage-points greater than the control group. The causal increase in the probability of being eurosceptic is sizeable, with the 5.97 percentage-point gap equating to a $35 \%$ rise vis-à-vis the control group. Adding pre-treatment covariates increases the point-estimate of the ITT to 6.2 percentage-points (an increase of $38 \%$ compared to the control group). The outcome of the ECJ's verdict exerted an important and sizeable negative effect on support for the EU, with those Spanish citizens randomly exposed to the verdict being significantly more eurosceptic than those who were not.

We now turn to assess the affect of the EU's judicial intervention on dissatisfaction with democracy. Figure 4 illustrates the ITT and covariate-adjusted ITT of the European court's decision in the Junqueras case on both dissatisfaction scaled 0 - 10 (lefthand panel) and the overall probability of being dissatisfied (right-hand panel). As in the case of euroscepticism, the European court's decision increases popular dissatisfaction with democracy. The modeled ITT of .32 is significant and sizeable, with treatment assignment increasing dissatisfaction by $6 \%$ relative to the control group (13\% of a standard deviation). Adding covariates to the model does not alter the magnitude or significance of the effect. The right-hand panel models the probability of being dissatisfied with democracy. The coefficient indicates a 5.6 percentage-point increase in the probability of being dissatisfied with democracy. This is a sizeable rise in dissatisfaction vis-à-vis the control group. Those interviewed pre-treatment have a probability of being dissatisfied with democracy equal to $38 \%$ whereas for those in 
Treatment effects on Euroscepticism

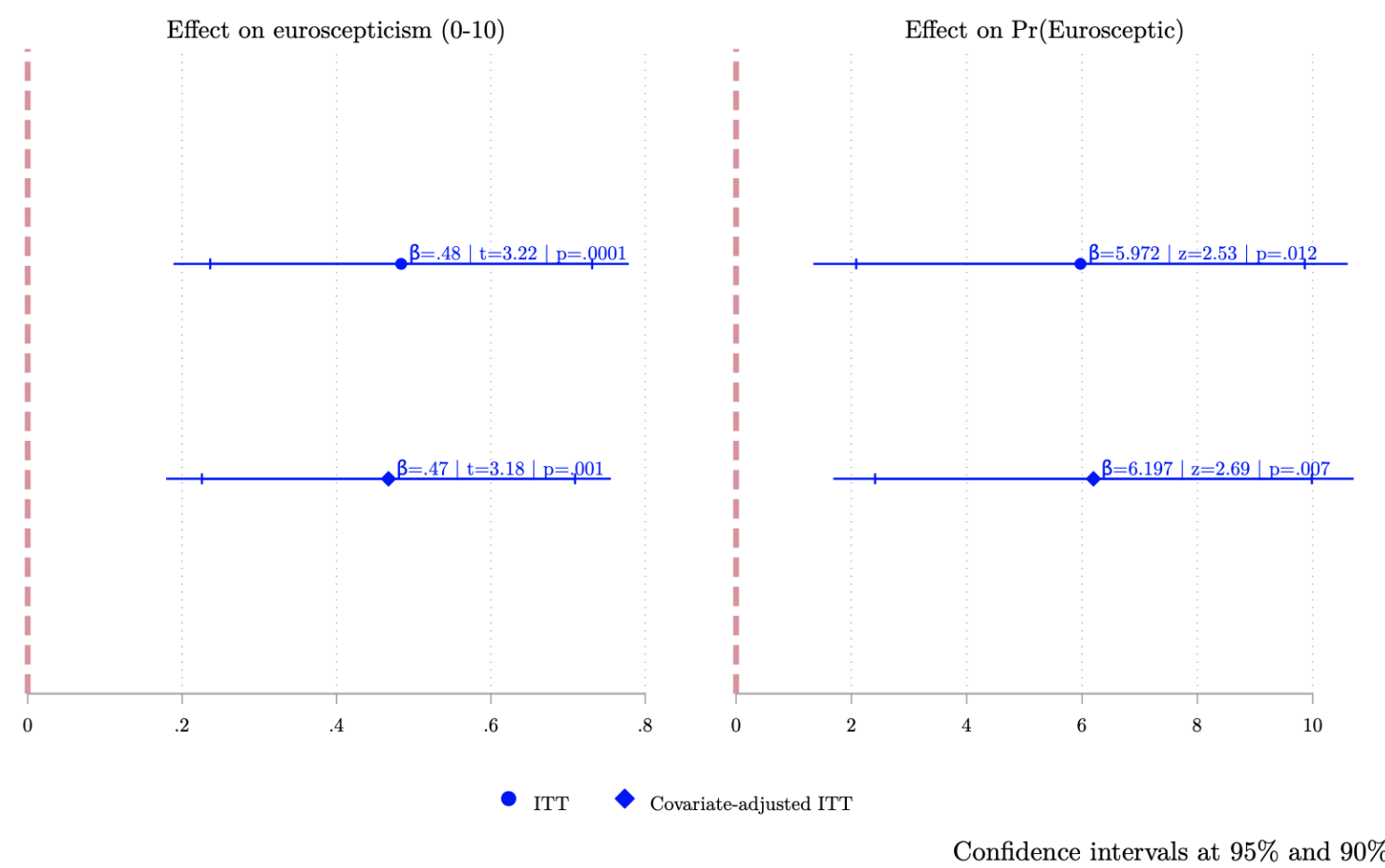

Figure 3: Effect on euroscepticism

treatment the probability is $13 \%$ greater at $43 \%$. Assessing the covariate-adjusted ITT as per Muñoz et al. (2020)'s matching recommendation reports significant effects (see Figure A9). Whilst the covariate-adjusted models we report here are both significant and positively signed, consistent with our theoretical expectations the rigour of the effect of dissatisfaction is weaker in comparison to that of euroscepticism. The evidence becomes weaker when decreasing the bandwidth size, presented in Figure A6, in which the coefficient tends towards zero with reduced bandwidths.

The size of the increase in polity scepticism caused by the ECJ is of a magnitude comparable to the attitudinal updates observed in other studies. Solaz et al. (2019)'s study on the effect of a government corruption scandal which occurred during survey fieldwork found an ITT of -.44 $(p<0.05)$ on government satisfaction scaled in the same way $(0-10)$ as our two core outcomes. Their observed effect falls neatly between our point-estimates of .48 (euroscepticism) and .32 (dissatisfaction with democracy). Also in line with Solaz et al. (2019), we observe a slight delay of a week or so in the emer- 
gence of the effect (see, however, Schraff (2020)). A comparison of the modelled effects across different temporal horizons is included in the online appendix material (Figure A5 \& A6).

An important consideration is whether this represents a shock that changes the base level of attitudes, whether it is an effect that decays quickly, or something in between. Unfortunately, similar designs as ours do not report their rate of decay. Empirically, our results, presented in Figures 8, A14 and A17, suggest that the increase in euroscepticism is stable even 30 days after the treatment date. Moreover, VOX, Spain's new radical right-wing party, has taken a more explicit eurosceptic turn in the aftermath of the ruling (Rama et al. 2021), which signals the potential for continued politicisation. VOX's attempt to own the eurosceptic space and party's continued attacks against the $\mathrm{EU}$, and the media coverage of the same, may serve to further ferment and consolidate eurosceptic attitudes amongst voters (Murphy and Devine 2018; Foos and Bischof 2019). At the same time, attitudes such as democratic satisfaction and euroscepticism are relatively stable and deeply-rooted which are unlikely to be permanently shifted by shocks such as the one we have presented. We are conservatively cautious in our claims regarding the temporal horizon of the identified effect. Whilst we cannot claim that the treatment-induced effect acts as a permanent shock, it is clear from the data that there is a relatively significant change up to, at least, one month following treatment.

\subsection{Partisan moderation?}

Our empirical analysis provides support for hypotheses 1 and, to a lesser extent, 2: judicial intervention from the EU court ruling against the position of the member state reduces popular support for the EU and increases dissatisfaction with democracy amongst citizens. The treatment effect we estimate captures the causal impact of the EU's ruling on the population but this average effect may mask significant moder- 
Treatment effects on Dissatisfaction with democracy

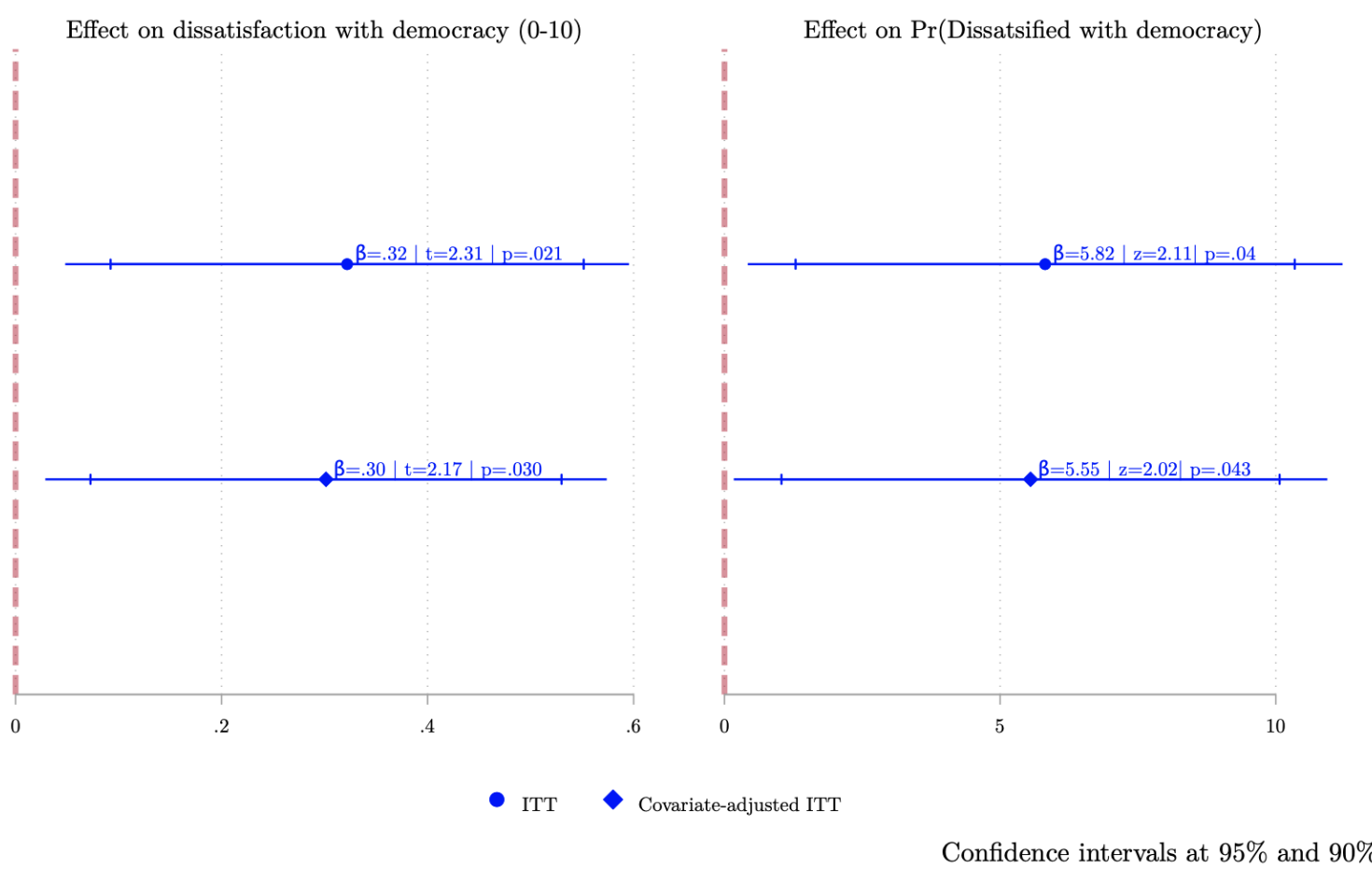

Figure 4: Effect on dissatisfaction with democracy

ating effects.

Hypothesis 3 posits that the effects will be conditioned by partisan alignment: given the partisan divide over the Catalan question, we might expect the ITT effect we observe to be moderated by citizens' partisan support. Spain's three right-wing parties, PP, Ciudadanos and VOX coined themselves as the country's only "Constitutional" parties that were dedicated to defend against the threat represented by the Catalan separatist movement to the unity of Spain. In the two general elections held in April and November 2019, the self-penned constitutional parties focused their campaign efforts on criticising the PSOE-led government for their management of the Catalan situation (Simón 2020) and their supporters were sourced form those with strong attachment to their national Spanish identity (Turnbull-Dugarte et al. 2020). Should the negative treatment effects we observe be the result of partisans moving to oppose an EU decision that goes against their political preferences, we would expect to see the negative treatment effect to only be observed for these parties' supporters. 


\begin{tabular}{lcc} 
Variables & Euroscepticism & Dissat. w/ democracy \\
\hline \multirow{2}{*}{ Treatment } & $0.40^{* *}$ & $0.32^{* *}$ \\
'Constitutional' voter & $(0.17)$ & $(0.16)$ \\
& $0.47^{* *}$ & -0.19 \\
Treatment ${ }^{* \prime}$ Constitutional' voter & $(0.19)$ & $(0.17)$ \\
& 0.41 & 0.01 \\
Constant & $(0.37)$ & $(0.34)$ \\
& $3.55^{* * *}$ & $5.17^{* * *}$ \\
& $(0.09)$ & $(0.08)$ \\
Observations & & 1,584 \\
R-squared & 1,481 & 0.00 \\
\hline
\end{tabular}

$$
\begin{aligned}
& \text { Robust standard errors in parentheses } \\
& \qquad * * * \mathrm{p}<0.01,{ }^{* *} \mathrm{p}<0.05,{ }^{*} \mathrm{p}<0.1
\end{aligned}
$$

Table 1 reports the effect of treatment conditioned on those who voted for any of the three so-called "constitutional" parties (PP, Ciudadanos, or VOX) who were most aggressively opposed to Catalan independence and focused on politicising these issues, and those who voted for any other party or abstained. Across all three models the interaction effect is insignificant and replications using self-identified ideological placement on the left-right axis, as opposed to vote recall, provide the same results (see Figure A21). There is no empirical evidence to support H3: the treatment effect we observe is largely symmetrical across voters stratified by either their partisan vote choice, or their ideological identification. We interpret the non-conditional nature of our treatment effect as indirect evidence in support of hypotheses 1 and 2, insofar as the effect is due to the ECJ ruling itself rather than (purely) motivated reasoning.

\subsection{Robustness tests}

We conduct a uniquely large range of robustness tests to demonstrate the validity and scope conditions of our results. In order to ensure our results our specific to our outcome of interest, We consider issue-based placebo tests, which we present in Figure 
$5 .{ }^{13}$ We show there is no effect on trust in the UN and immigration attitudes, but there is on trust in the legal system. This makes us confident that there is no wider shift in preferences due to some unidentified confounder and that our identified effect is specific to preferences over democracy, integration, and the legal judgement. Further placebos are presented in appendix Figure A10.

- Euroscepticism

- Dissatisfaction with democracy

- Disrust in legal system

$\Delta$ Distrust in UN

- Immigration attitudes

Left-right position

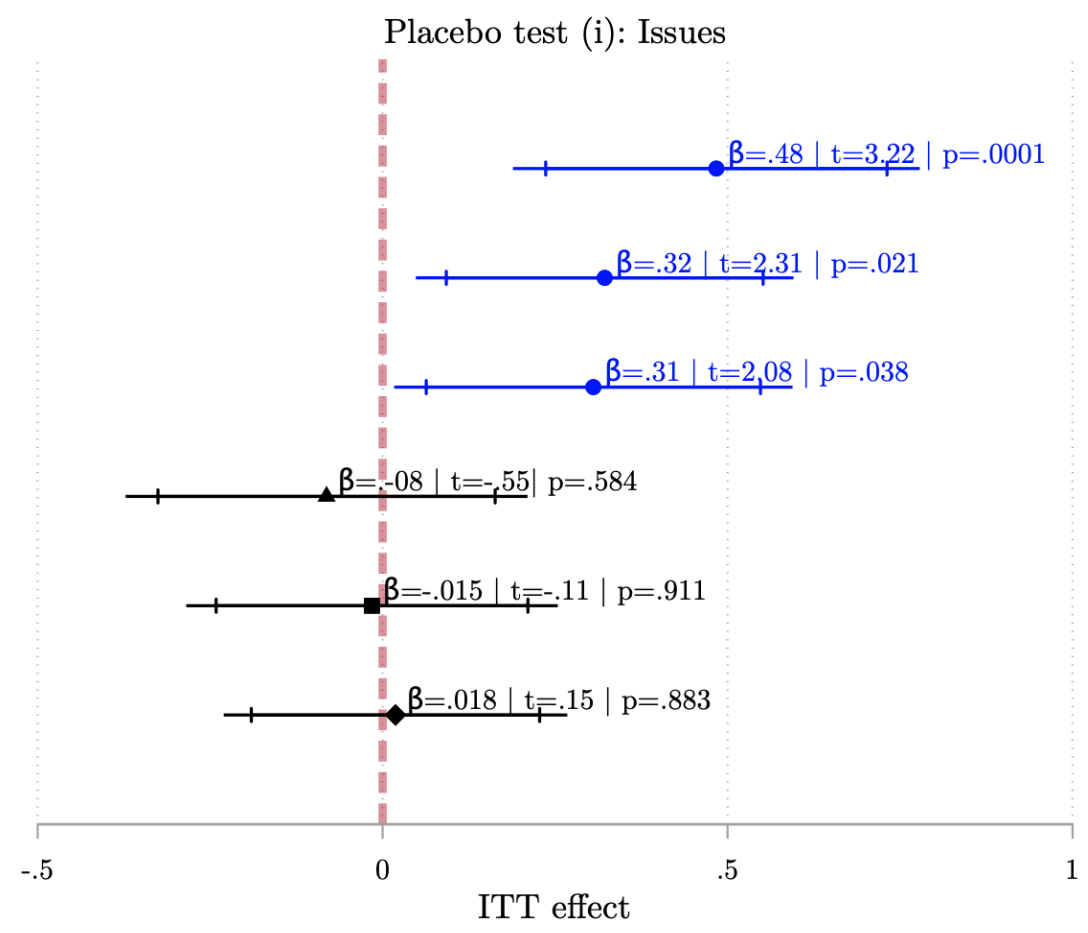

Confidence intervals at $95 \%$ and $90 \%$

Figure 5: Placebo test (i): ITT if ECJ ruling on alternative outcomes

We consider different country placebos in order to ensure our results are limited to Spain (and therefore the ECJ judgement). Croatia and Latvia's fieldwork dates overlapped Spain's and had a number of observations on either side of the treatment threshold. ${ }^{14}$ Figure 6 models the treatment effect on three different outcomes and provide strong evidence that our identified effect occurred only in Spain.

To provide evidence that we have not just observed an effect on this date out of chance,

\footnotetext{
${ }^{13}$ All of the placebos are measured in the same range as the main dependent variable on an elevenpoint $(0$ - 10) scale.

${ }^{14}$ Treatment assignment in Croatia is $8.73 \%(\mathrm{~N}=158)$ of the total Croatian sample $(\mathrm{N}=1,180)$. Treatment assignment in Latvia is $12.85 \%(\mathrm{~N}=118)$ of the total Latvian sample $(\mathrm{N}=918)$. Difference-indifference models are also reported in the appendix.
} 


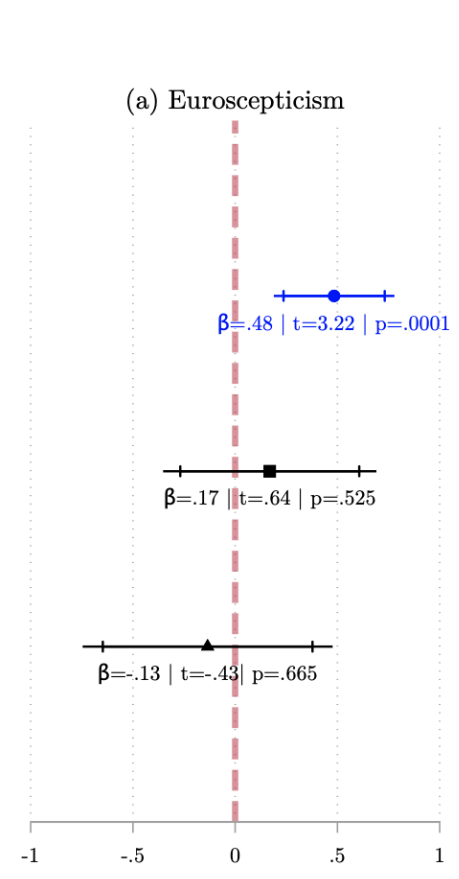

Placebo test (ii): Countries
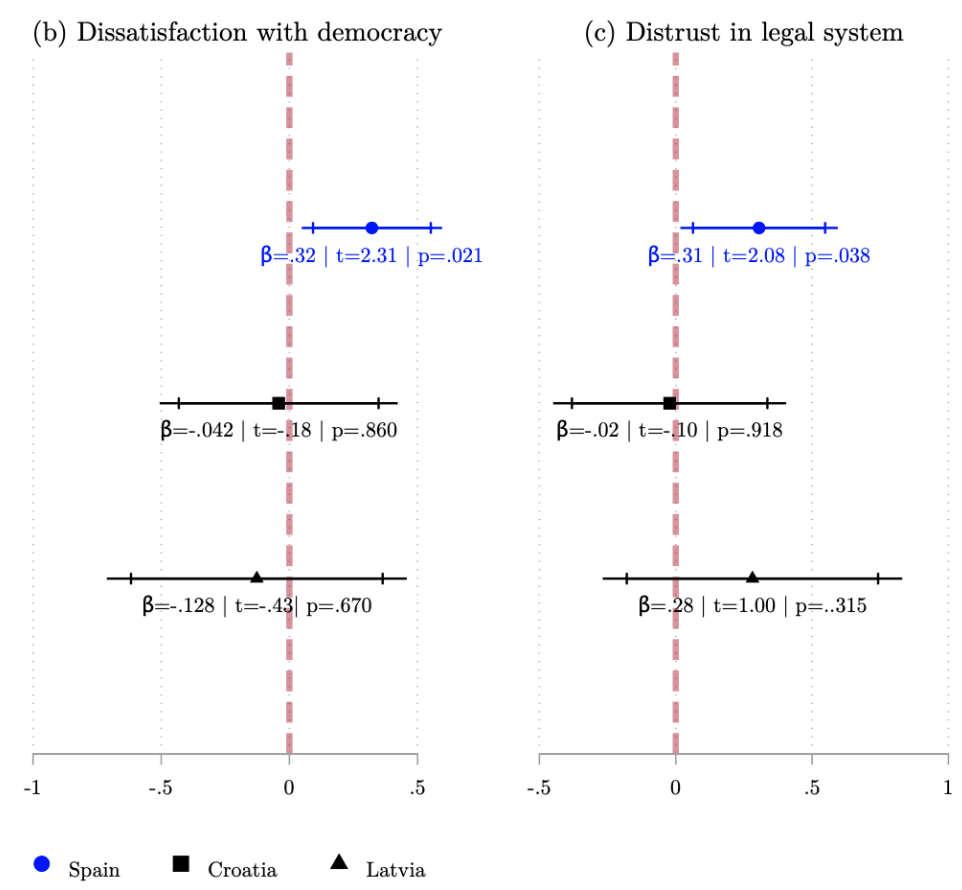

Confidence intervals at $95 \%$ and $90 \%$

Figure 6: Placebo test (ii): ITT of ECJ ruling in different member states

we randomise the date of treatment assignment creating a placebo treatment date and model its effect on euroscepticism, dissatisfaction with democracy, distrust in the legal system, and distrust in the UN (placebo). Figure 7 reports the results of 1,000 iterations. The vertical dashed line indicates the reported coefficient. In the case of the effect on our two core dependent variables (upper panel of Figure 7), our observed effects are significantly larger than the 1,000 iterations we compute with the placebo dates. In the case of our placebo issue, the permutation tests show that the observed null effects we report are replicated extensively.

A similar concern is that the results are driven by spurious time trends. To test for this possibility, we first visualise the levels of euroscepticism and dissatisfaction with democracy reported over the fieldwork period which shows no incremental trend in the pre-treatment period and a rise following the ECJ decision, which we visualise in Figure 8.

Whilst we acknowledge that there is no immediate discontinuous shift in levels, partic- 


\section{Permutation tests}

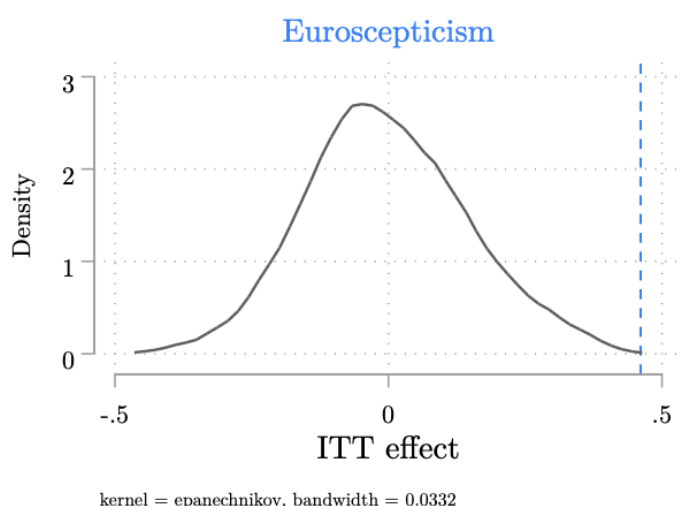

Distrust in the legal system

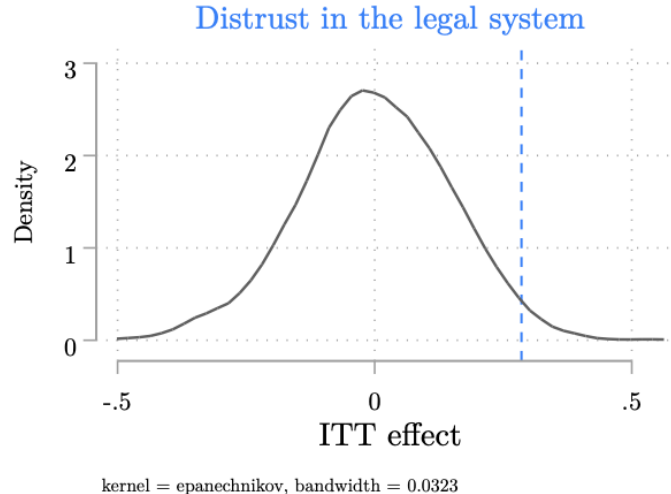

Dissatisfaction with democracy

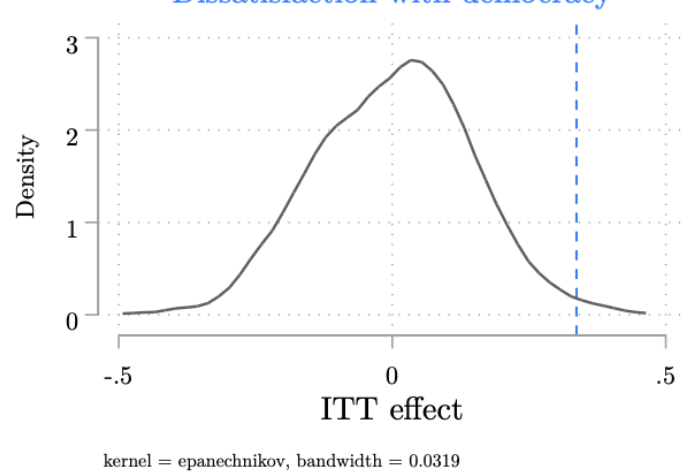

Placebo: Distrust in the UN

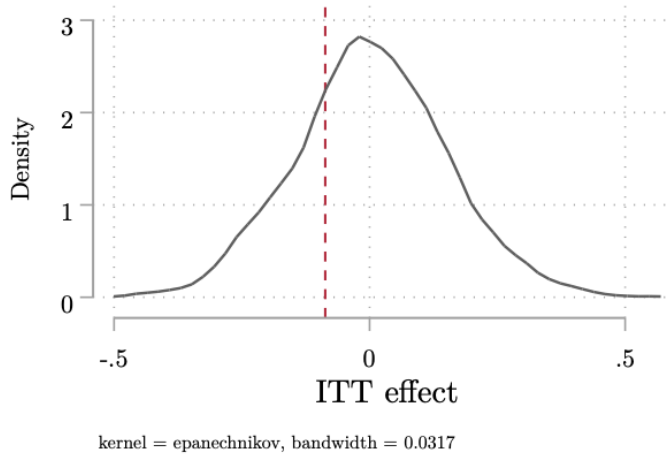

Figure 7: Permutations on main outcomes \& placebo

ularly for democratic satisfaction, we are encouraged by the shift in direction of trends in both cases and especially euroscepticism. We conduct a number of tests for temporal trends. First, we take the median interview date of the control group sample as a placebo date (Muñoz et al. 2020). Carrying out this additional robustness test demonstrates the absence of influential pre-treatment time trends (Figure A7). Third, we estimate a linear regression model estimating the effect of time on our main outcomes in the pre-treatment period, which shows that attitudes towards the EU and dissatisfaction with democracy remained static across the pre-treatment period (Figure A25). Finally, we visualise the collinearity between euroscepticism and attitudes towards immigration, which demonstrates that during the pre-treatment period, euroscepticism and immigration preferences followed the same (horizontal) trend (Figure A4). This collinearity was disrupted in the post-treatment period when attitudes towards 
Polynomials with $95 \%$ confidence intervals
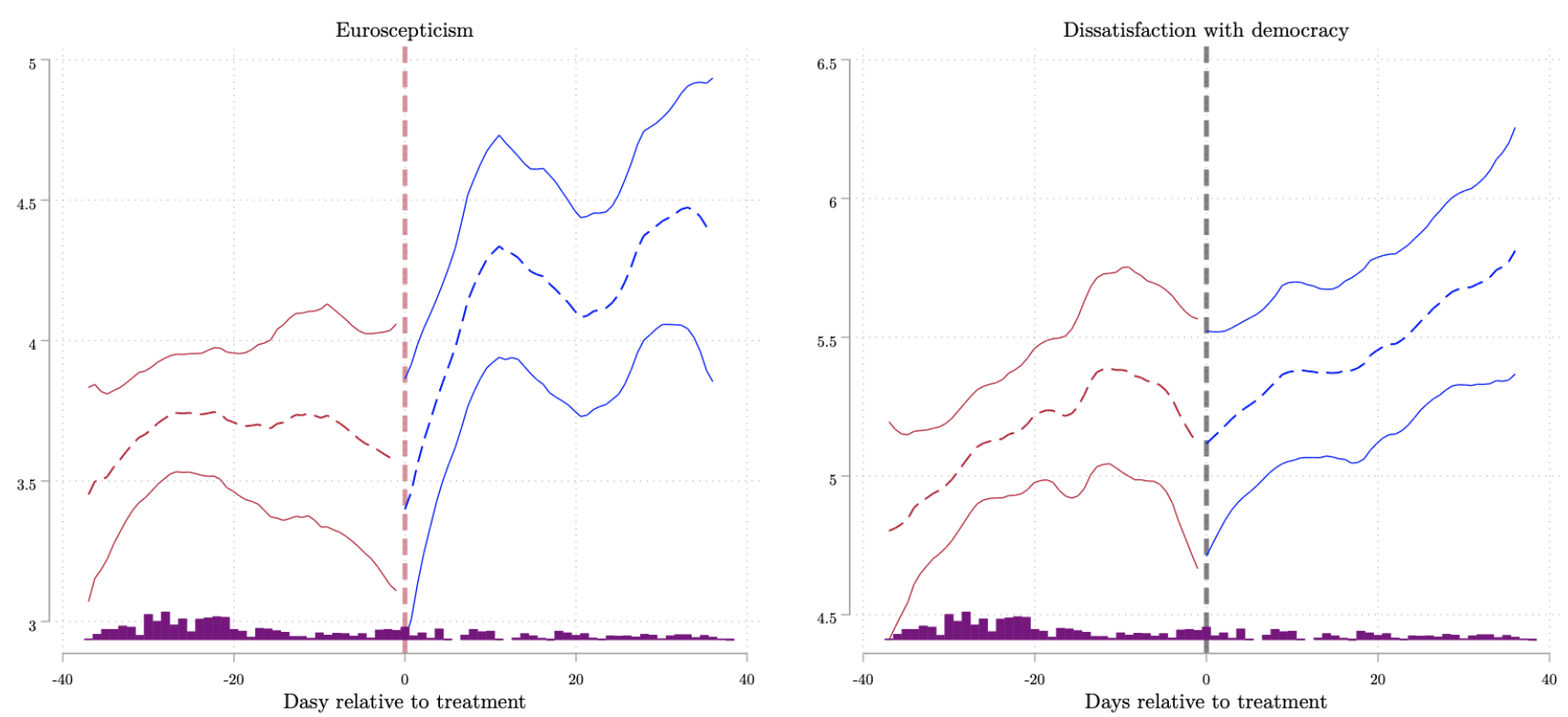

Figure 8: Testing for spurious time trends

euroscepticism increased whilst immigration preferences remained largely static. A similar pattern is observed in the collinear relationship between euroscepticism and trust in the UN.

Finally, we conduct two additional modelling techniques: regression discontinuity (RD) and a kernel-based regularized least squares (KRLS) (Hainmueller and Hazlett 2014). Our results are tempered by these alternative modelling strategies, presented in the Appendix. The RD model shows that there is no statistically significant jump in either euroscepticism or dissatisfaction (as in figure 8), but the point estimates (0.041 and 0.015 respectively) are in the same direction and of similar a magnitude as those presented above. Sensitivity tests show that 7-10 days after treatment the effect size stabilises across all window lengths. We do not necessarily expect a clear continuous jump on time $t+1$. A number of studies have indicated that there is usually a lag between an event and attitudinal or behavioural outcomes: Giani and Meón (2019) advocate a two-week window for the ESS; Solaz et al. (2019) show a one-week lag for the effect of corruption scandals, and Devine (2020) shows a 7-10 day lag for the effect of the Brexit referendum. Our results are consistent with these, though others do show 
discontinuous attitudinal changes (Schraff 2020).

The KRLS analysis indicates coefficients consistent with the RD and main analyses, with a significant coefficient of treatment on both dissatisfaction and euroscepticism. When including a time trend variable, the effects become insignificant. Yet visualising the marginal effects of the treatment variable - a benefit of the KRLS approach shows that the majority of the marginal effects are greater than zero including time or not. This is much weaker for dissatisfaction, however. The marginal effect of time is centred over zero for euroscepticism and over 0.002 for dissatisfaction. From our extensive robustness tests, we are confident in our conclusion that the ECJ ruling did induce a negative effect on polity support, but also wish to report these additional tests.

In an additional exploratory analysis presented in the Appendix, we also test for conditional effects. Empirically, we show that the effect of treatment is not moderated by past participation, political interest, or education: proxies for a range of relevant attributes but particularly for the possibility that only highly engaged or educated citizens were aware of the EU decisions (Turnbull-Dugarte 2020).

\section{Conclusions}

This paper has explored the causal impact of judicial decisions taken by the EU's supranational court, by specifically focusing on the potential for ECJ rulings to shape polity scepticism in the form of euroscepticism and dissatisfaction with democracy. Drawing upon the four distinct yet interconnected bodies of literature related to the europeanisation effect of the ECJ, the role of EU interventions in shaping domestic outcomes, euroscepticism, and political support, we argue that ECJ decision can be viewed in many ways as an illustrative example of EU intervention. Building on the existing intervention literature centred on the financial and Eurozone crises, we the- 
orise that politicised ECJ interventions can serve as an information cue to citizens regarding the sovereignty-diluting nature of EU membership. Essentially, ECJ decisions not only catalyse change in EU integration or europeanisation going forward (Pollack 2018), but can also be viewed as a signal of the weakened sovereignty of member states that has already taken place and induce the perception of the EU as an illegitimate and intervening external actor in domestic affairs. We suggest that this can lead to increased opposition to the idea of European integration and reduced satisfaction with the way democracy works in their country.

Our hypotheses were threefold and posited that: judicial decision from the EU's supranational court can lead to increases in euroscepticism and dissatisfaction with democracy, but this will be moderated by pre-existing beliefs, namely partisanship. Leveraging the natural exogeneity of exposure to a salient and highly publicised ECJ ruling, we test our argument via the analysis of a quasi-experiment in Spain. The findings of our analysis show that judicial actions from the EU play a powerful role in shaping polity support. Our results provide strong and robust support for our first hypothesis: the average citizen in Spain became significantly more likely to be eurosceptic as a result of the ECJ's decision regarding the Junqueras case on Catalan independence.

In terms of dissatisfaction with democracy, our findings are less robust. We argue that judicial decisions taken by the ECJ can be viewed by voters as a form of external intervention from the EU in that that judicial decisions can upset the perceived legitimacy of nationally accepted practices (Pollack 2018). We find that, on average, exposure to the ECJ ruling in Spain does indeed reduce citizens' satisfaction with democracy. The magnitude and significance of the effect, however, weaker in comparison to the rise in euroscepticism. Finally, we find no support for our third hypothesis: the effect is not moderated by party identification.

Whilst the findings we observe come from Spain, we believe that Spain actually represents a "tough case" for our theoretical model, so there is reason to expect similar findings to be observed elsewhere. Since joining the European Community in 1986, 
Spain has remained one of the most europhile nations within the collection of EU member states (De Vries 2018). Despite being one of the country's hit hardest by the Eurozone crisis and one of the six states subjected to economic intervention by the Troika (Devine 2019), euroscepticism has failed to take hold in Spain in either the party system or amongst the electorate. Given that we observe a significant and sizeable ECJ-induced euroscepticism effect in a national context where the baseline rate of euroscepticim is low and the issue-based mobilisation of political entrepreneurs has been absent, it is likely the case the same (if not a greater effect) could be observed in states where political opportunities exist that are more primed to activate euroscepticism. The case of Junqueras in Spain is undoubtedly of a special character given the political ramifications of the Court's decision. It is worth noting, however, that in the current climate of increased politicisation of EU integration (Bressanelli et al. 2020), there are very few decisions taken by EU actors that are not subject to increased debate in the domestic arena. The court is no exception to this. As Werner (2016) highlights, the decisions of the supranational court "face much more public outrage and political backlash than ever before" so we can assume that this backlash has similar polity spceticism-inducing effects beyond the Spanish case. We argue, therefore, that the validity of our findings are not limited to Spain but rather provide an empiricallysupported theoretical understanding of the the role of the EU court in moulding polity support for the EU.

A competing causal account consistent with our results is that this is little to do with sovereignty per se but the importance of public opinion and the intervention of countermajoritarian institutions, such as courts. Perhaps our results are due to this more general mechanism than anything at all to do with sovereignty or the European Union's multilevel structure. To our knowledge, there is little evidence of this one way or another in Europe. In the United States, there is a large literature which studies the Supreme Court's effect on public opinion. In a relatively recent review and set of experimental treatments, Linos and Twist (2016) find that Supreme Court decisions actually increase public acceptance of a given policy because it endows that policy with 
legitimacy. If this were the case, we might expect to find some partisan or regional heterogeneity in which those on the side of the ECJ's decision view it as legitimacyenhancing, which we do not find. All said, we accept the possibility that our results may be part of a broader trend of counter-majoritarian institutions overruling public opinion or the decisions of representative institutions, but would argue that the low legitimacy of supranational courts (at least vis-à-vis domestic courts) is more likely to be legitimacy-decreasing than legitimacy-enhancing (Schlipphak and Treib 2017).

Beyond a focus on polity scepticism, our findings speak to a wider audience concerned with the potential for European integration to threaten the perceived autonomy of member states. This work has recently been centred on the question of economic intervention, brought about the Eurozone crisis, and the conditionality of this economic intervention can have detrimental consequences for political support. The implications of our findings, in line with those of the EU's economic intervention, that EU intervention within domestic politics can have adverse effects on political support. The potential for public backlash against the ECJ represents a significant dilemma for the EU: in the course of affirming its founding principles or ensuring compliance with supranational law, it may empower its detractors. 


\section{References}

Abou-Chadi, Tarik, and Markus Wagner. 2020. “Electoral fortunes of social democratic parties: do second dimension positions matter?" Journal of European Public Policy 27 (2): $246-272$.

Armingeon, Klaus, and Kai Guthmann. 2014. “Democracy in crisis? The declining support for national democracy in European countries, 2007-2011". European Journal of Political Research 53 (3): 423-442.

Armingeon, Klaus, Kai Guthmann, and David Weisstanner. 2016. "How the Euro divides the union: The effect of economic adjustment on support for democracy in Europe". Socio-Economic Review 14 (1): 1-26.

Armstrong, Kenneth A. 2017. Brexit time: leaving the EU - why, how and when? Cambridge: Cambridge University Press.

Baldini, Gianfranco, Edoardo Bressanelli, and Stella Gianfreda. 2020. “Taking back control? Brexit, sovereignism and populism in Westminster (2015-17)". European Politics and Society 21 (2): 219-234.

Bickerton, C. 2012. European Integration: From Nation-States to Member States. Oxford: Oxford University Press.

Blauberger, Michael, and Susanne K. Schmidt. 2017. “The European Court of Justice and its political impact". West European Politics 40 (4): 907-918.

- . 2014. "Welfare migration? Free movement of EU citizens and access to social benefits". Research and Politics 1 (3): 1-7. doi:10.1177/2053168014563879.

Bol, Damien, et al. 2020. "The effect of COVID-19 lockdowns on political support: Some good news for democracy?" European Journal of Political Research EarlyView. doi:10.1111/1475-6765.12401.

Boomgaarden, Hajo G., et al. 2011. "Mapping EU attitudes: Conceptual and empirical dimensions of Euroscepticism and EU support". European Union Politics 12 (2): 241266. 
Borriello, Arthur, and Nathalie Brack. 2019. "'I want my sovereignty back!' A comparative analysis of the populist discourses of Podemos, the 5 Star Movement, the FN and UKIP during the economic and migration crises". Journal of European Integration 41 (7): 833-853.

Bressanelli, Edoardo, Christel Koop, and Christine Reh. 2020. “EU Actors under pressure: politicisation and depoliticisation as strategic responses". Journal of European Public Policy 27 (3): 329-341.

Csehi, Robert, and Edit Zgut. 2020. “'We won't let Brussels dictate us': Eurosceptic populism in Hungary and Poland". European Politics and Society Online First. doi:10 . $1080 / 23745118.2020 .1717064$.

Dawson, Mark, Bruno De Witte, and Elise Muir. 2013. Judicial activism at the European Court of Justice. Cheltenham: Edward Elgar Publishing.

De Vries, Catherine. 2018. Euroscepticism and the future of European integration. Oxford: Oxford University Press.

Devine, Daniel. 2020. “Discrete Events and Hate Crimes: The Causal Role of the Brexit Referendum". Social Science Quarterly Online First. doi:10.1111/ssqu . 12896.

- . 2019. "Perceived government autonomy, economic evaluations, and political support during the Eurozone crisis". West European Politics EarlyView. doi:10 . 1080 / 01402382.2019 .1675130 .

Ferrín, Mónica, and Hanspeter Kriesi. 2016. How Europeans View and Evaluate Democracy. Oxford: Oxford University Press.

Ferwerda, Jeremy, Jens Hainmueller, and Chad J. Hazlett. 2017. “Kernel-Based Regularized Least Squares in R ( KRLS ) and Stata ( Krls )". Journal of Statistical Software 79 (3).

Foos, Florian, and Daniel Bischof. 2019. "Can the tabloid media create Eurosceptic attitudes? A quasi-experiment on media influence in England". http: //www . florianfoos . net/resources/Foos_Bischof_Hillsborough.pdf. 
Foster, Chase, and Jeffry Frieden. 2017. “Crisis of trust: Socio-economic determinants of Europeans' confidence in government". European Union Politics 18 (4): 511-535.

Giani, Marco, and Pierre Guillaume Meón. 2019. “Global Racist Contagion following Donald Trump's Election". British Journal of Political Science EarlyView. doi:10 .1017/ S0007123419000449.

Hainmueller, Jens, and Chad Hazlett. 2014. “Kernel Regularized Least Squares: Reducing Misspecification Bias with a Flexible and Interpretable Machine Learning Approach". Political Analysis 22 (2): 143-168.

Halikiopoulou, Daphne, Kyriaki Nanou, and Sofia Vasilopoulou. 2012. “The paradox of nationalism: The common denominator of radical right and radical left euroscepticism". European Journal of Political Research 51 (4): 504-539.

Hobolt, Sara B., and Catherine E. De Vries. 2016. “Public Support for European Integration". Annual Review of Political Science 19 (1): 413-432.

Hofmann, Andreas. 2018. "Resistance against the Court of Justice of the European Union". International Journal of Law in Context 14 (2): 258-274.

Kelemen, R. Daniel. 2017. Europe's other democratic deficit: National authoritarianism in Europe's Democratic Union.

- . 2016. "The Court of Justice of the European Union in the Twenty-First Century". Law and Contemporary Problems 79:117-140.

- . 2012. "The political foundations of judicial independence in the European Union". Journal of European Public Policy 19 (1): 43-58.

Kumlin, Staffan. 2011. "Claiming blame and giving credit? unintended effects of how government and opposition frame the europeanization of welfare". European Union Politics 12 (4): 575-595.

Larsson, Olof, and Daniel Naurin. 2019. "Split vision: Multidimensionality in the European Union's legal policy space". International Studies Quarterly 63 (3): 492-506. 
Linos, Katerina, and Kimberly Twist. 2016. “The Supreme Court, the Media, and Public Opinion: Comparing Experimental and Observational Methods" [inlangen]. The Journal of Legal Studies 45 (2): 32.

Mair, Peter. 2009. "Representative versus responsible government". MPIfG Working Paper 09 /8.

- . 2013. Ruling the Void: The Hollowing of Western Democracy. London: Verso.

Martinsen, Dorte Sindbjerg. 2009. "Conflict and conflict management in the crossborder provision of healthcare services". West European Politics 32 (4): 792-809.

- . 2015. "Judicial influence on policy outputs? the political constraints of legal integration in the european union". Comparative Political Studies 48 (12): 1622-1660.

Muñoz, Jordi, Albert Falcó-Gimeno, and Enrique Hernández. 2020. “Unexpected Event during Survey Design: Promise and Pitfalls for Causal Inference". Political Analysis 28 (2): 186-206.

Murphy, Justin, and Daniel Devine. 2018. “Does Media Coverage Drive Public Support for UKIP or Does Public Support for UKIP Drive Media Coverage?" British Journal of Political Science EarlyView. ISSN: 14692112. doi:10 .1017/S0007123418000145.

Pollack, Mark A. 2003. The Engines of European Integration: Delegation, Agency, and Agenda Setting in the EU. Oxford: Oxford University Press.

- . 2018. "The Legitimacy of the European Court of Justice". In Legitimacy and International Courts, ed. by Nienke Grossman, Harlan Grant Cohen, and Andreas Follesdal, 143-173. Cambridge: Cambridge University Press.

Rama, José, et al. 2021. VOX: The Rise of the Spanish Populist Radical Right. London: Routledge.

Sánchez-Cuenca, Ignacio. 2017. "From a Deficit of Democracy to a Technocratic Order: The Postcrisis Debate on Europe". Annual Review of Political Science 20 (1): 351-369. 
Saurugger, Sabine, and Clement Fontan. 2019. “The judicialisation of EMU politics: Resistance to the EU's new economic governance mechanisms at the domestic level". European Journal of Political Research 58 (4): 1066-1087.

Scharpf, Fritz W. 1999. Governing in Europe: Effective and democratic? Oxford: Oxford University Press.

- . 2013. "Legitimacy Intermediation in the Multilevel European Polity and Its Collapse in the Euro Crisis". In Staatstätigkeiten, Parteien und Demokratie, ed. by Manfred G. Schmidt, 567-596. Springer. doi:10.1007/978-3-658-01853-5\{\_\}32.

Schlipphak, Bernd, and Oliver Treib. 2017. "Playing the blame game on Brussels: the domestic political effects of EU interventions against democratic backsliding". Journal of European Public Policy 24 (3): 352-365.

Schmidt, Vivien A. 2013. “Democracy and Legitimacy in the European Union Revisited: Input, Output and 'Throughput'". Political Studies 61 (1): 2-22.

- . 2006. Democracy in Europe: The EU and National Polities.

Schraff, Dominik. 2020. “Asymmetric ratification standards and popular perceptions of legitimacy". Journal of European Public Policy Online First. doi:10 . 1080/13501763. 2020.1853796 .

Schraff, Dominik, and Frank Schimmelfennig. 2019. “Eurozone bailouts and national democracy: Detachment or resilience?" European Union Politics 20 (3): 361-383.

Simón, Pablo. 2020. “The Multiple Spanish Elections of April and May 2019: The Impact of Territorial and Left-right Polarisation". South European Society and Politics EarlyView. doi:10.1080/13608746 .2020.1756612.

Solaz, Hector, Catherine E. De Vries, and Roosmarijn A. de Geus. 2019. "In-Group Loyalty and the Punishment of Corruption". Comparative Political Studies 52 (6): 896926.

Stone Sweet, Alec. 2010. “The European Court of Justice and the judicialization of EU governance". Living Reviews in European Governance. doi:10 .2139/ssrn. 1583345. 
Turnbull-Dugarte, Stuart J. 2019. “Explaining the end of Spanish exceptionalism and electoral support for Vox". Research E Politics 6 (2): 1-8. doi:10 . 1177/2053168019851680.

- . 2020. "Why vote when you cannot choose? EU intervention and political participation in times of constraint". European Union Politics 21 (3): 406-428.

Turnbull-Dugarte, Stuart J., José Rama, and Andrés Santana. 2020. “The Baskerville's dog suddenly started barking: voting for VOX in the 2019 Spanish general elections". Political Research Exchange 2 (1). doi:10 . 1080/2474736X . 2020 . 1781543.

Weale, Albert. 2016. “Nostalgic Democracy Triumphs over Democratic Internationalism". Political Quarterly 87 (3): 352-354.

Werner, Benjamin. 2016. "Why is the Court of Justice of the European Union not more Contested? Three Mechanisms of Opposition Abatement". Journal of Common Market Studies 54 (6): 1449-1464. 


\section{Appendix}

\section{Balance}

Table A1: Balance: Model predicting treatment assignment

\begin{tabular}{|c|c|c|c|c|}
\hline$X$ & $\begin{array}{c}(1) \\
\text { Full sample }\end{array}$ & $\begin{array}{l}(2) \\
\pm 10\end{array}$ & $\begin{array}{l}(3) \\
\pm 15\end{array}$ & $\begin{array}{l}(4) \\
\pm 20\end{array}$ \\
\hline Gender (male) & $\begin{array}{c}0.05 \\
(0.14)\end{array}$ & $\begin{array}{l}0.62^{* *} \\
(0.30)\end{array}$ & $\begin{array}{l}0.49^{*} \\
(0.25)\end{array}$ & $\begin{array}{c}0.22 \\
(0.21)\end{array}$ \\
\hline Age 25-34 & $\begin{array}{c}0.36 \\
(0.29)\end{array}$ & $\begin{array}{l}-0.24 \\
(0.55)\end{array}$ & $\begin{array}{c}0.36 \\
(0.47)\end{array}$ & $\begin{array}{c}0.21 \\
(0.41)\end{array}$ \\
\hline Age $35-44$ & $\begin{array}{l}0.53^{* *} \\
(0.27)\end{array}$ & $\begin{array}{c}0.52 \\
(0.55)\end{array}$ & $\begin{array}{l}0.87^{*} \\
(0.47)\end{array}$ & $\begin{array}{c}0.51 \\
(0.40)\end{array}$ \\
\hline Age $45-54$ & $\begin{array}{c}0.24 \\
(0.26)\end{array}$ & $\begin{array}{c}0.33 \\
(0.54)\end{array}$ & $\begin{array}{c}0.31 \\
(0.45)\end{array}$ & $\begin{array}{c}0.06 \\
(0.40)\end{array}$ \\
\hline Age 55-64 & $\begin{array}{l}-0.01 \\
(0.28)\end{array}$ & $\begin{array}{c}0.54 \\
(0.58)\end{array}$ & $\begin{array}{c}0.48 \\
(0.49)\end{array}$ & $\begin{array}{c}0.05 \\
(0.42)\end{array}$ \\
\hline Age 65-74 & $\begin{array}{l}-0.52 \\
(0.35)\end{array}$ & $\begin{array}{c}0.58 \\
(0.80)\end{array}$ & $\begin{array}{c}0.37 \\
(0.65)\end{array}$ & $\begin{array}{l}-0.05 \\
(0.54)\end{array}$ \\
\hline AgeL 75+ & $\begin{array}{l}-0.58 \\
(0.44)\end{array}$ & $\begin{array}{l}-0.16 \\
(0.88)\end{array}$ & $\begin{array}{l}-0.16 \\
(0.75)\end{array}$ & $\begin{array}{l}-0.57 \\
(0.62)\end{array}$ \\
\hline Lower secondary & $\begin{array}{c}0.14 \\
(0.25)\end{array}$ & $\begin{array}{c}0.43 \\
(0.61)\end{array}$ & $\begin{array}{l}-0.09 \\
(0.49)\end{array}$ & $\begin{array}{l}-0.15 \\
(0.40)\end{array}$ \\
\hline Upper secondary & $\begin{array}{c}0.27 \\
(0.27)\end{array}$ & $\begin{array}{c}0.83 \\
(0.69)\end{array}$ & $\begin{array}{c}0.05 \\
(0.55)\end{array}$ & $\begin{array}{c}0.17 \\
(0.45)\end{array}$ \\
\hline Post secondary & $\begin{array}{c}0.25 \\
(0.35)\end{array}$ & $\begin{array}{c}0.34 \\
(0.83)\end{array}$ & $\begin{array}{l}-0.24 \\
(0.68)\end{array}$ & $\begin{array}{c}0.14 \\
(0.58)\end{array}$ \\
\hline Tertiary & $\begin{array}{c}0.14 \\
(0.26)\end{array}$ & $\begin{array}{c}0.74 \\
(0.65)\end{array}$ & $\begin{array}{l}-0.03 \\
(0.52)\end{array}$ & $\begin{array}{l}-0.20 \\
(0.42)\end{array}$ \\
\hline Income & $\begin{array}{l}-0.02 \\
(0.03)\end{array}$ & $\begin{array}{c}0.07 \\
(0.07)\end{array}$ & $\begin{array}{c}0.06 \\
(0.06)\end{array}$ & $\begin{array}{c}0.02 \\
(0.05)\end{array}$ \\
\hline Left-right position & $\begin{array}{l}-0.00 \\
(0.03)\end{array}$ & $\begin{array}{c}0.06 \\
(0.07)\end{array}$ & $\begin{array}{c}0.05 \\
(0.06)\end{array}$ & $\begin{array}{c}0.06 \\
(0.05)\end{array}$ \\
\hline Constant & $\begin{array}{c}-1.14^{* * *} \\
(0.37)\end{array}$ & $\begin{array}{c}-1.75^{* *} \\
(0.84)\end{array}$ & $\begin{array}{l}-1.22^{*} \\
(0.67)\end{array}$ & $\begin{array}{l}-0.79 \\
(0.54)\end{array}$ \\
\hline Observations & 1,031 & 201 & 275 & 398 \\
\hline
\end{tabular}


Table A2: Bivariate covariate comparison by treatment condition

\begin{tabular}{lccc}
\hline Covariate & Treatment & Control & Difference \\
\hline Gender & .51 & .506 & -.005 \\
Age & 45.76 & 49.63 & $3.88^{* * *}$ \\
Education & 3.07 & 2.97 & -.092 \\
Income & 5.11 & 5.13 & .015 \\
Left-right position & 4.45 & 4.43 & -.021 \\
Employment status & 2.19 & 2.58 & $.39^{* * *}$ \\
Household size & 3.08 & 2.92 & $-.16^{* *}$ \\
Marital status & 5.46 & 5.34 & $-.12^{*}$ \\
Church attendance & .88 & .92 & .039 \\
\hline \multicolumn{4}{c}{${ }^{* * *} \mathrm{p}<0.01,{ }^{* *} \mathrm{p}<0.05,{ }^{*} \mathrm{p}<0.1$} \\
\end{tabular}

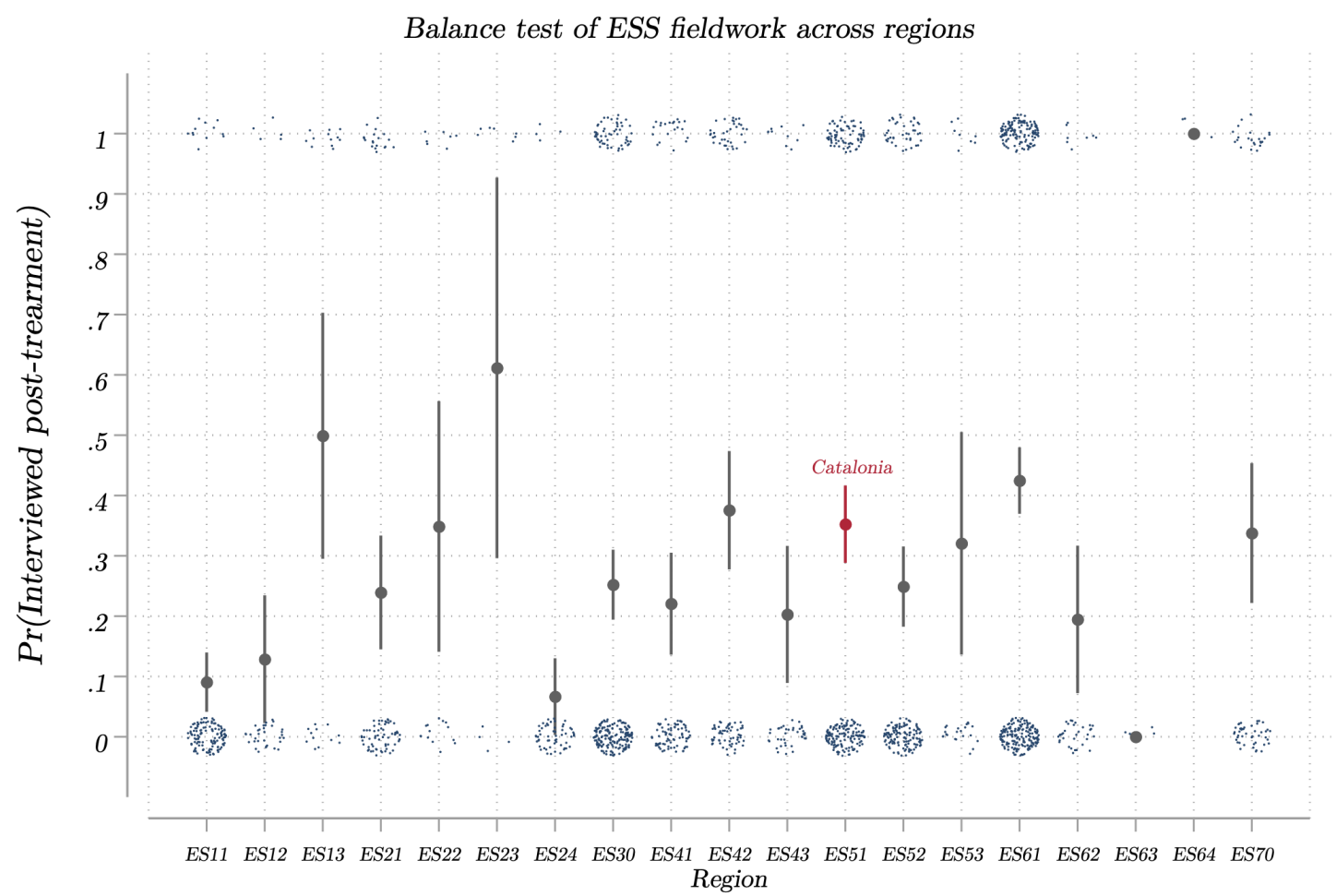

Figure A1: Regional balance in treatment assignment 
Table A3: Partisan balance in treatment assignment

(1)

Variables

Treatment assignment

Party supporter (baseline: PP voter)

PSOE voter

$-0.00$

$(0.21)$

Unidas Podemos voter

0.05

$(0.25)$

Ciudanos voter

0.29

$(0.31)$

VOX voter

0.15

$(0.27)$

Other

0.19

(0.18)

Constant

$-1.02^{* * *}$

(0.17)

Observations

1,668

Robust standard errors (two-tailed) in parentheses ${ }^{* * *} \mathrm{p}<0.01,{ }^{* *} \mathrm{p}<0.05,{ }^{*} \mathrm{p}<0.1$ 
Proportion of missing values in outcome variables by treatment assignment
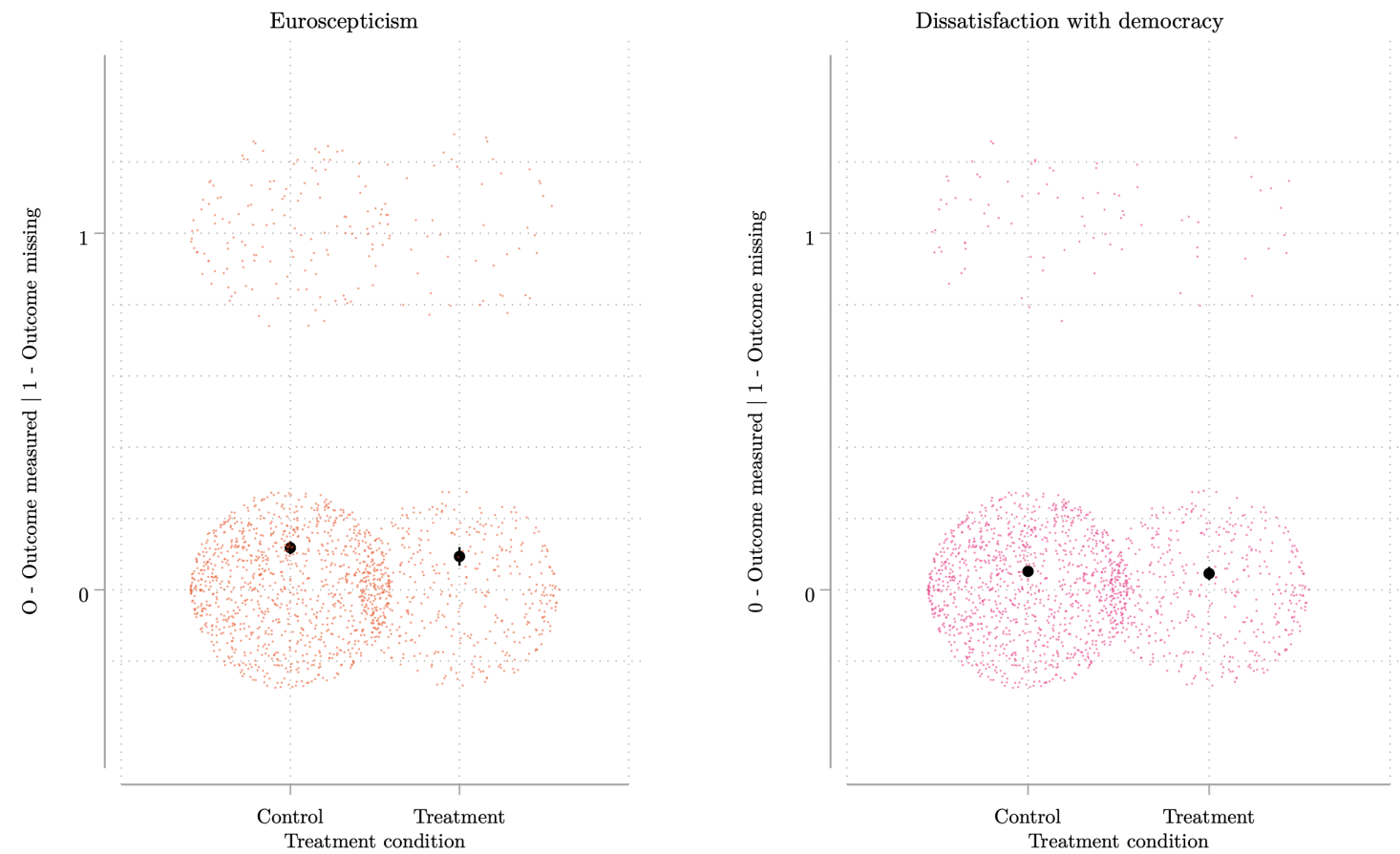

Figure A2: Missing outcome values \& treatment assignment

\section{Main models}


Table A4: Main regression model

\begin{tabular}{|c|c|c|c|c|}
\hline Variables & $\begin{array}{c}(1) \\
\text { Euroscepticism } \\
\end{array}$ & $\begin{array}{c}(2) \\
\text { Euroscepticism } \\
\end{array}$ & $\begin{array}{c}\text { (3) } \\
\text { Dissat. w/ democracy }\end{array}$ & $\begin{array}{c}\text { (4) } \\
\text { Dissat. w/ democracy }\end{array}$ \\
\hline Treatment & $\begin{array}{c}0.48^{* * *} \\
(0.15)\end{array}$ & $\begin{array}{c}0.48^{* * *} \\
(0.18)\end{array}$ & $\begin{array}{l}0.32^{* *} \\
(0.14)\end{array}$ & $\begin{array}{c}0.22 \\
(0.17)\end{array}$ \\
\hline Gender (male) & & $\begin{array}{l}-0.46^{* * *} \\
(0.16)\end{array}$ & & $\begin{array}{l}-0.36^{* *} \\
(0.16)\end{array}$ \\
\hline Age: $25-34$ & & $\begin{array}{l}0.58^{*} \\
(0.30)\end{array}$ & & $\begin{array}{c}0.37 \\
(0.31)\end{array}$ \\
\hline Age: $35-44$ & & $\begin{array}{l}0.50^{*} \\
(0.30)\end{array}$ & & $\begin{array}{c}0.25 \\
(0.30)\end{array}$ \\
\hline Age: $45-54$ & & $\begin{array}{c}0.35 \\
(0.29)\end{array}$ & & $\begin{array}{l}-0.18 \\
(0.29)\end{array}$ \\
\hline Age: 55-64 & & $\begin{array}{c}0.07 \\
(0.30)\end{array}$ & & $\begin{array}{l}-0.52^{*} \\
(0.30)\end{array}$ \\
\hline Age: $65-74$ & & $\begin{array}{l}-0.05 \\
(0.33)\end{array}$ & & $\begin{array}{l}-0.49 \\
(0.34)\end{array}$ \\
\hline Age: 75+ & & $\begin{array}{c}0.38 \\
(0.44)\end{array}$ & & $\begin{array}{l}-0.35 \\
(0.42)\end{array}$ \\
\hline Lower secondary & & $\begin{array}{c}0.00 \\
(0.28)\end{array}$ & & $\begin{array}{c}0.13 \\
(0.27)\end{array}$ \\
\hline Upper secondary & & $\begin{array}{l}-0.47 \\
(0.31)\end{array}$ & & $\begin{array}{l}-0.53^{*} \\
(0.30)\end{array}$ \\
\hline Post secondary & & $\begin{array}{l}-0.78^{* *} \\
(0.36)\end{array}$ & & $\begin{array}{c}0.27 \\
(0.41)\end{array}$ \\
\hline Tertiary & & $\begin{array}{l}-1.23^{* * *} \\
(0.28)\end{array}$ & & $\begin{array}{l}-0.20 \\
(0.27)\end{array}$ \\
\hline Income & & $\begin{array}{l}-0.02 \\
(0.03)\end{array}$ & & $\begin{array}{l}0.05^{*} \\
(0.03)\end{array}$ \\
\hline Left-right position & & $\begin{array}{l}0.20^{* * *} \\
(0.04)\end{array}$ & & $\begin{array}{l}-0.08^{* *} \\
(0.04)\end{array}$ \\
\hline Constant & $\begin{array}{l}3.66^{* * *} \\
(0.08)\end{array}$ & $\begin{array}{l}3.26^{* * *} \\
(0.41)\end{array}$ & $\begin{array}{l}5.12^{* * *} \\
(0.07)\end{array}$ & $\begin{array}{l}5.67^{* * *} \\
(0.40)\end{array}$ \\
\hline Observations & 1,481 & 973 & 1,584 & 1,015 \\
\hline R-squared & 0.01 & 0.10 & 0.00 & 0.04 \\
\hline
\end{tabular}

Robust standard errors (two-tailed) in parentheses ${ }^{* * *} \mathrm{p}<0.01,{ }^{* *} \mathrm{p}<0.05,{ }^{*} \mathrm{p}<0.1$ 
Table A5: Logistic regression models using dichotomous dependent variables

(1) (2) (3) (4)

Variables Eurosceptic Eurosceptic Dissatisfied Dissatisfied

Treatment

$0.38^{* * *}$

$0.56^{* * *}$

$0.24^{* *}$

0.11

Gender (male)

$(0.14)$

$(0.18)$

$(0.11)$

$(0.15)$

Age: 25-34

0.02

$-0.23^{*}$

$0.66^{*}$

0.43

$(0.38)$

(0.27)

Age: 35-44

0.36

0.35

(0.36)

Age: 45-54

0.41

$-0.13$

(0.35)

$(0.25)$

Age: 55-64

0.18

$-0.28$

(0.38)

(0.26)

Age: $65-74$

0.26

$-0.15$

$(0.42)$

(0.30)

Age: $75+$

0.63

$-0.02$

$(0.47)$

(0.37)

Lower secondary

0.07

0.28

(0.26)

$(0.23)$

Upper secondary

$-0.31$

$-0.06$

$(0.32)$

$(0.26)$

Post secondary

$-0.55$

(0.41)

(0.33)

Tertiary

$-1.07^{* * *}$

0.21

(0.34)

(0.24)

Income

$-0.04$

$0.05^{*}$

$(0.04)$

(0.03)

Left-right position

$0.11^{* * *}$

$-0.10^{* * *}$

Constant

$-1.59^{* * *}$

(0.04)

(0.03)

$-2.01^{* * *}$

$-0.50^{* * *}$

$-0.37$

(0.08)

(0.46)

(0.06)

(0.35)

Observations 1,481

973

1,584

1,015

Robust standard errors (two-tailed) in parentheses ${ }^{* * *} \mathrm{p}<0.01,{ }^{* *} \mathrm{p}<0.05,{ }^{*} \mathrm{p}<0.1$ 
Table A6: Main regression model without imputation of missing covariate values

\begin{tabular}{|c|c|c|c|c|}
\hline Variables & $\begin{array}{c}(1) \\
\text { Euroscepticism }\end{array}$ & $\begin{array}{c}(2) \\
\text { Euroscepticism }\end{array}$ & $\begin{array}{c}\text { (3) } \\
\text { Dissat. w/ democracy }\end{array}$ & $\begin{array}{c}(4) \\
\text { Dissat. w/ democracy }\end{array}$ \\
\hline Treatment & $\begin{array}{c}0.48^{* * *} \\
(0.15)\end{array}$ & $\begin{array}{c}0.48^{* * *} \\
(0.18)\end{array}$ & $\begin{array}{l}0.32^{* *} \\
(0.14)\end{array}$ & $\begin{array}{c}0.22 \\
(0.17)\end{array}$ \\
\hline Gender (male) & & $\begin{array}{l}-0.46^{* * *} \\
(0.16)\end{array}$ & & $\begin{array}{l}-0.36^{* *} \\
(0.16)\end{array}$ \\
\hline Age: $25-34$ & & $\begin{array}{l}0.58^{*} \\
(0.30)\end{array}$ & & $\begin{array}{c}0.37 \\
(0.31)\end{array}$ \\
\hline Age: $35-44$ & & $\begin{array}{l}0.50^{*} \\
(0.30)\end{array}$ & & $\begin{array}{c}0.25 \\
(0.30)\end{array}$ \\
\hline Age: $45-54$ & & $\begin{array}{c}0.35 \\
(0.29)\end{array}$ & & $\begin{array}{l}-0.18 \\
(0.29)\end{array}$ \\
\hline Age: 55-64 & & $\begin{array}{c}0.07 \\
(0.30)\end{array}$ & & $\begin{array}{l}-0.52^{*} \\
(0.30)\end{array}$ \\
\hline Age: $65-74$ & & $\begin{array}{l}-0.05 \\
(0.33)\end{array}$ & & $\begin{array}{l}-0.49 \\
(0.34)\end{array}$ \\
\hline Age: 75+ & & $\begin{array}{c}0.38 \\
(0.44)\end{array}$ & & $\begin{array}{l}-0.35 \\
(0.42)\end{array}$ \\
\hline Lower secondary & & $\begin{array}{c}0.00 \\
(0.28)\end{array}$ & & $\begin{array}{c}0.13 \\
(0.27)\end{array}$ \\
\hline Upper secondary & & $\begin{array}{l}-0.47 \\
(0.31)\end{array}$ & & $\begin{array}{l}-0.53^{*} \\
(0.30)\end{array}$ \\
\hline Post secondary & & $\begin{array}{l}-0.78^{* *} \\
(0.36)\end{array}$ & & $\begin{array}{c}0.27 \\
(0.41)\end{array}$ \\
\hline Tertiary & & $\begin{array}{l}-1.23 * * * \\
(0.28)\end{array}$ & & $\begin{array}{l}-0.20 \\
(0.27)\end{array}$ \\
\hline Income & & $\begin{array}{l}-0.02 \\
(0.03)\end{array}$ & & $\begin{array}{l}0.05^{*} \\
(0.03)\end{array}$ \\
\hline Left-right position & & $\begin{array}{l}0.20^{* * *} \\
(0.04)\end{array}$ & & $\begin{array}{l}-0.08^{* *} \\
(0.04)\end{array}$ \\
\hline Constant & $\begin{array}{l}3.66^{* * *} \\
(0.08)\end{array}$ & $\begin{array}{l}3.26^{* * *} \\
(0.41)\end{array}$ & $\begin{array}{l}5.12^{* * *} \\
(0.07)\end{array}$ & $\begin{array}{l}5.67^{* * *} \\
(0.40)\end{array}$ \\
\hline Observations & 1,481 & 973 & 1,584 & 1,015 \\
\hline R-squared & 0.01 & 0.10 & 0.00 & 0.04 \\
\hline
\end{tabular}

Robust standard errors (two-tailed) in parentheses ${ }^{* * *} \mathrm{p}<0.01,{ }^{* *} \mathrm{p}<0.05,{ }^{*} \mathrm{p}<0.1$ 
Table A7: Models with regional FE

\begin{tabular}{|c|c|c|c|c|}
\hline Variables & $\begin{array}{c}\text { (1) } \\
\text { Euroscepticism }\end{array}$ & $\begin{array}{c}\text { (2) } \\
\text { Euroscepticism }\end{array}$ & $\begin{array}{c}\text { (3) } \\
\text { Dissat. w/ democracy }\end{array}$ & $\begin{array}{c}\text { (4) } \\
\text { Dissat. w/ democracy }\end{array}$ \\
\hline Treatment & $\begin{array}{l}0.41^{* * *} \\
(0.15)\end{array}$ & $\begin{array}{l}0.36^{*} \\
(0.19)\end{array}$ & $\begin{array}{l}0.27^{*} \\
(0.14)\end{array}$ & $\begin{array}{c}0.14 \\
(0.18)\end{array}$ \\
\hline Constant & $\begin{array}{c}3.26^{* * *} \\
(0.22)\end{array}$ & $\begin{array}{c}2.96^{* * *} \\
(0.44)\end{array}$ & $\begin{array}{c}5.16^{* * *} \\
(0.20)\end{array}$ & $\begin{array}{c}5.44^{* * *} \\
(0.43)\end{array}$ \\
\hline $\begin{array}{l}\text { Observations } \\
\text { R-squared } \\
\text { Regional FE } \\
\text { Individual controls }\end{array}$ & $\begin{array}{l}1,481 \\
0.03 \\
\text { Yes } \\
\text { No }\end{array}$ & $\begin{array}{l}973 \\
0.12 \\
\text { Yes } \\
\text { Yes }\end{array}$ & $\begin{array}{l}1,584 \\
0.07 \\
\text { Yes } \\
\text { No }\end{array}$ & $\begin{array}{l}1,015 \\
0.11 \\
\text { Yes } \\
\text { Yes }\end{array}$ \\
\hline
\end{tabular}

Robust standard errors (two-tailed) in parentheses

$$
{ }^{* * *} \mathrm{p}<0.01,{ }^{* *} \mathrm{p}<0.05,{ }^{*} \mathrm{p}<0.1
$$


Robustness \& sensitivity tests 

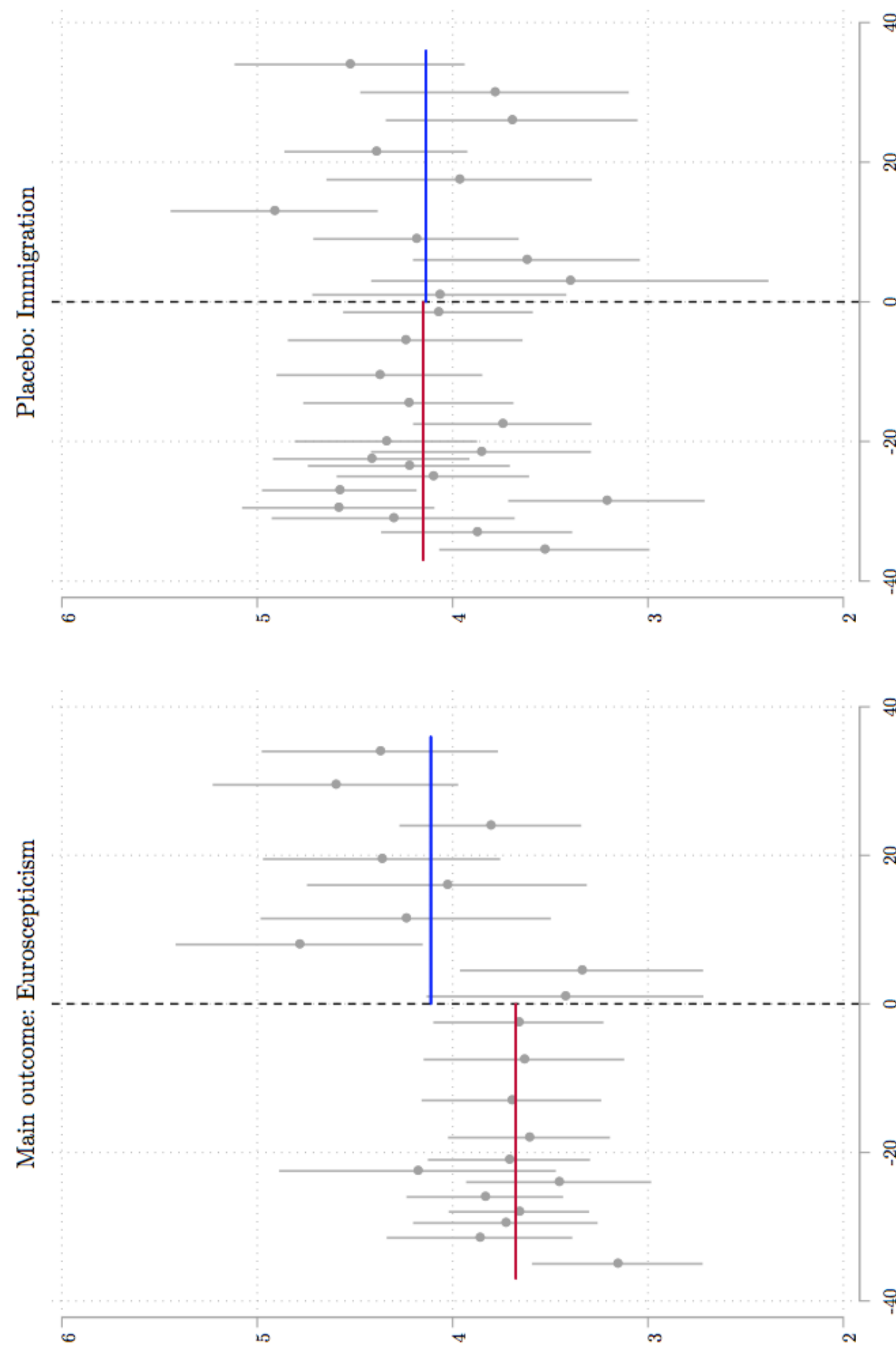

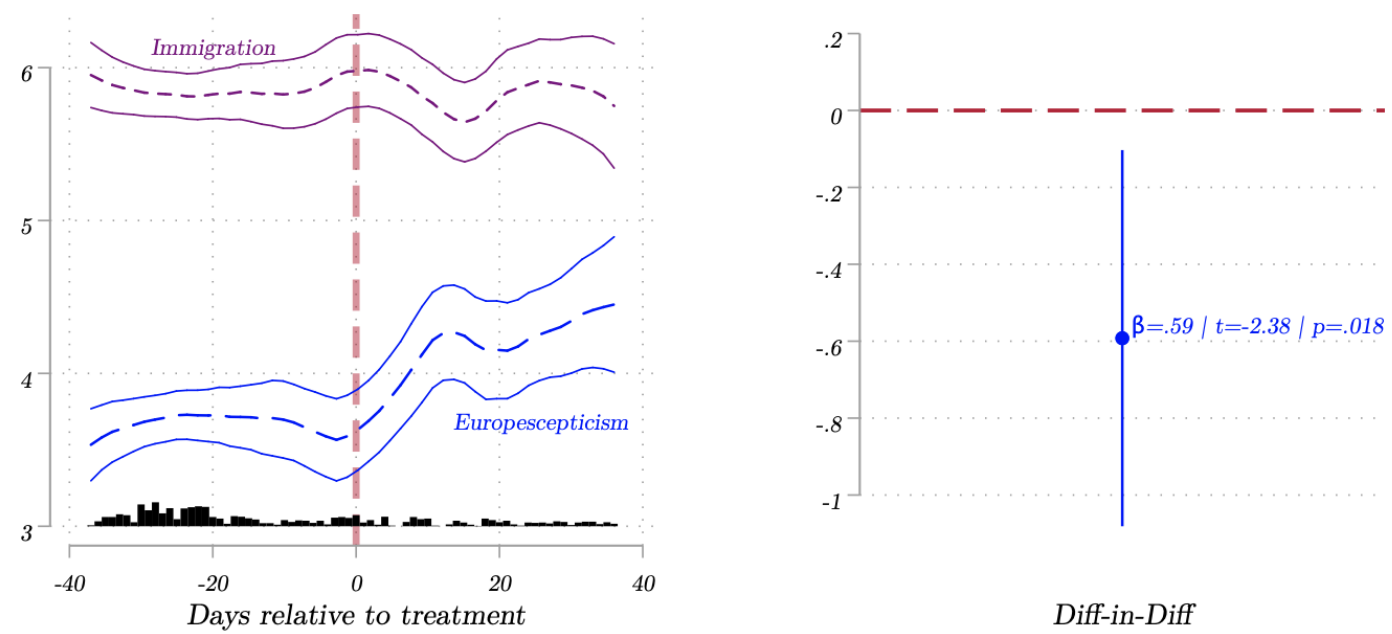

Diff-in-Diff
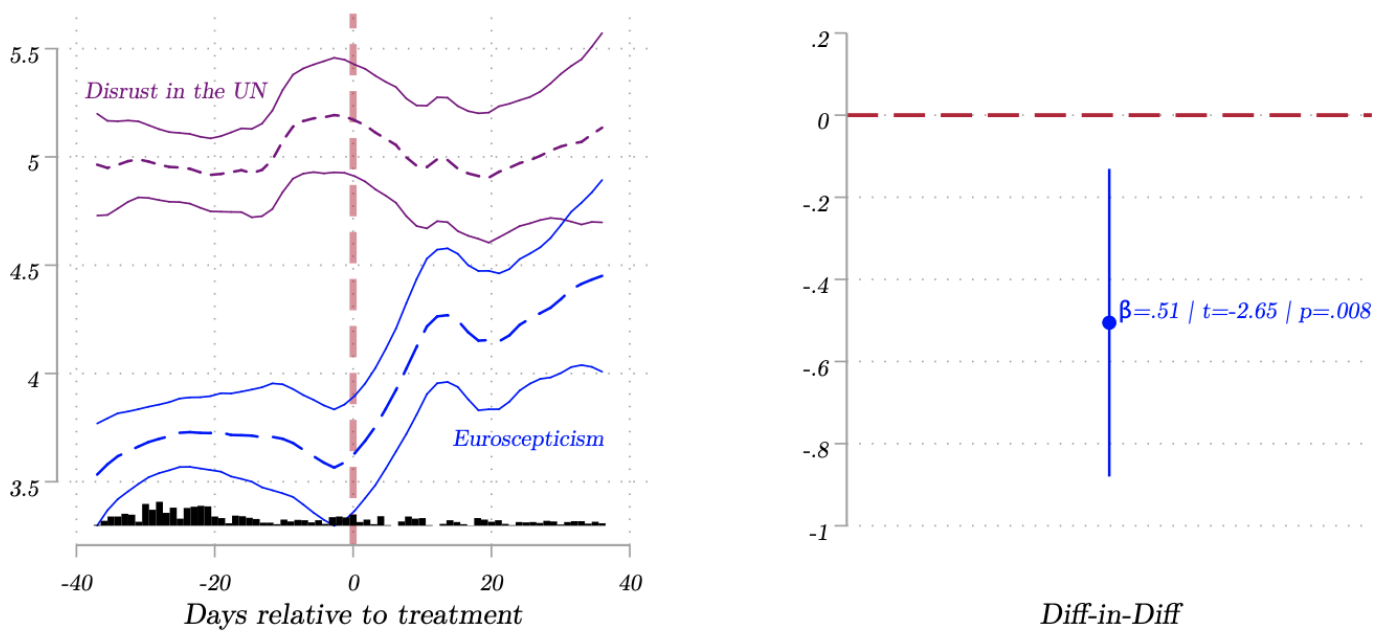

Diff-in-Diff

Figure A4: Diff-in-Diff of variable trends 


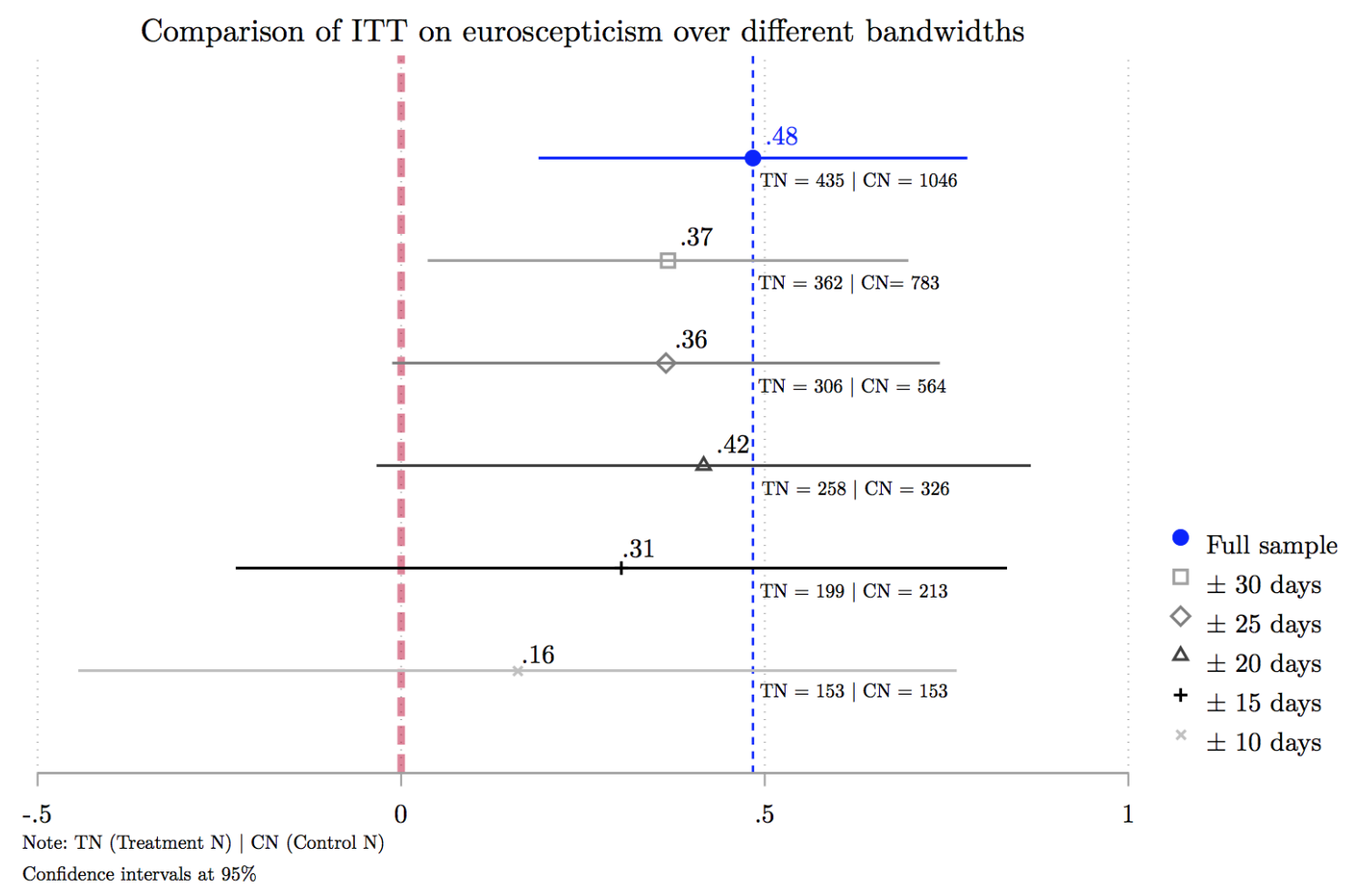

Figure A5: Alternative bandwidths: euroscepticism 
Comparison of ITT on democratic dissatisfaction over different bandwidths

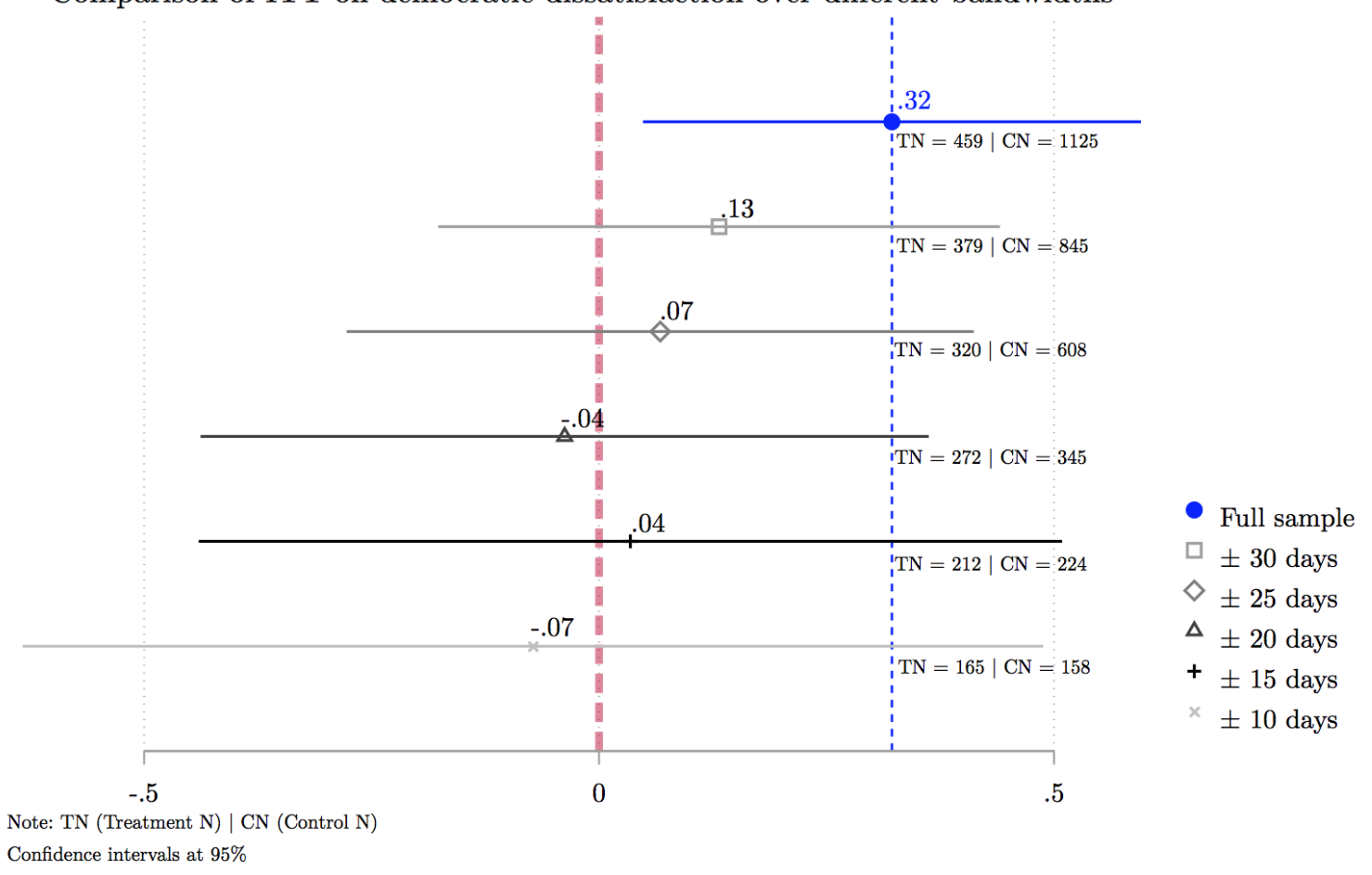

Figure A6: Alternative bandwidths: dissatisfaction 
Placebo date to the left of treatment using median date of control group as placebo threshold
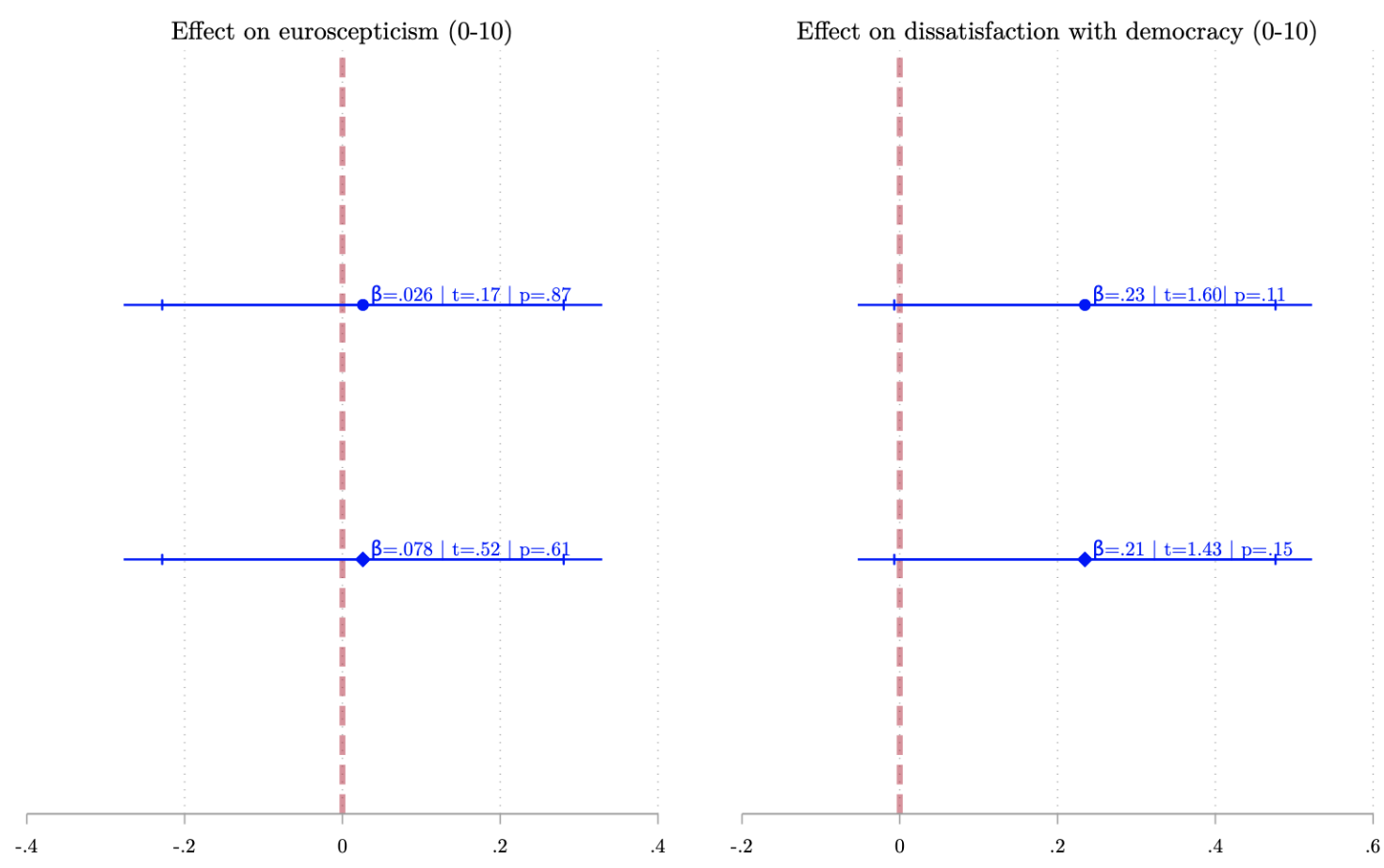

Figure A7: Placebo testing for pre-existing time trends

In Figure A9 we present results from near-neighbour matching (NNM). NNM matches similar individuals from the treatment and control groups, which we have matched on our covariates (perfect matching on gender). This serves the purpose of providing an additional robustness test against the possibility that our pre- and post-treatment samples differ in some important way. We also 'oversample' the neighbours, such that increasing neighbours uses more information to construct the counterfactual. Supporting our claim of as-if-random assignment, there is almost no change in our estimates and the changes are trivial and insignificant. 

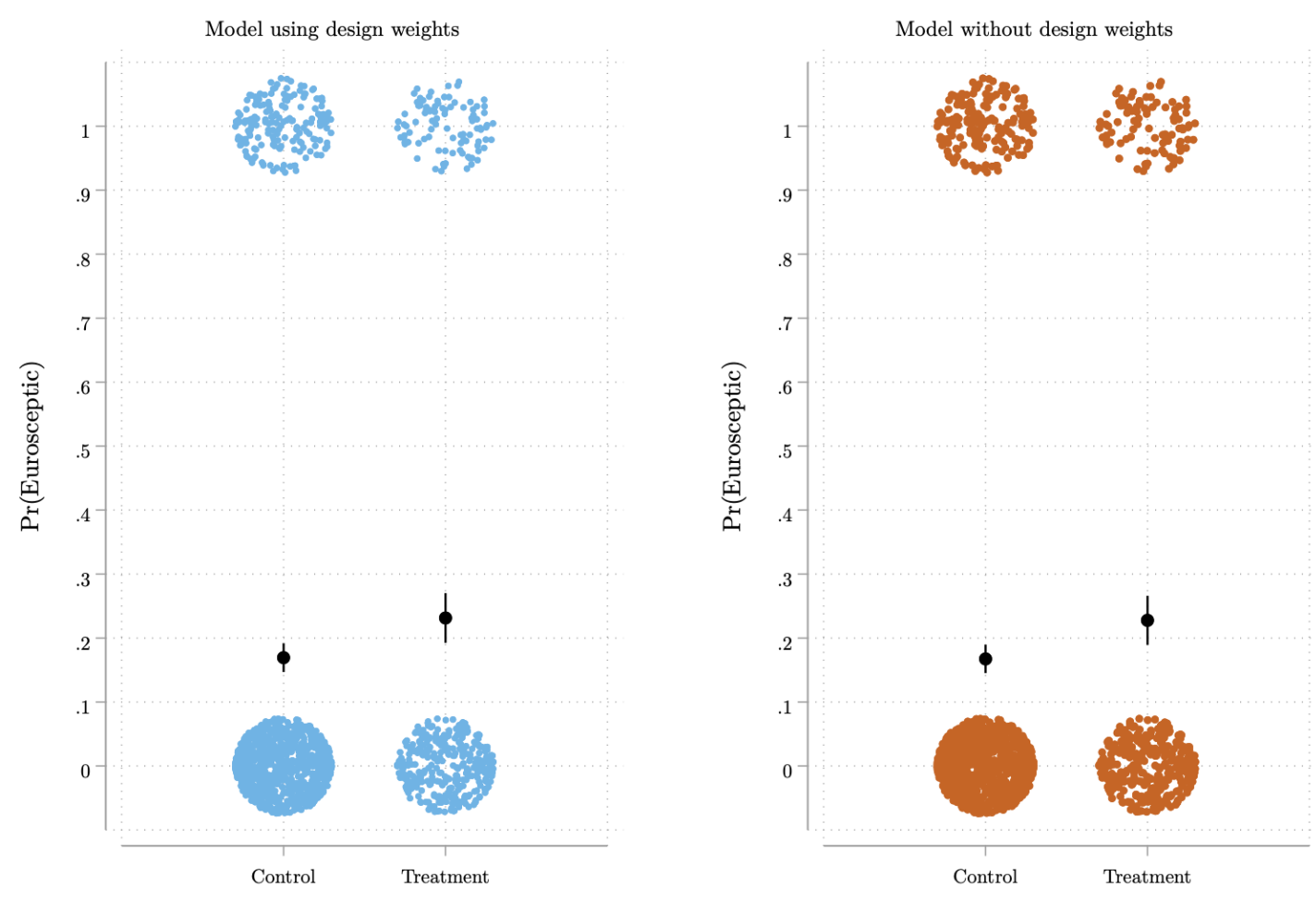

Figure A8: Comparison of weighted and unweighted estimations 
Robustness test: matching

Euroscepticism

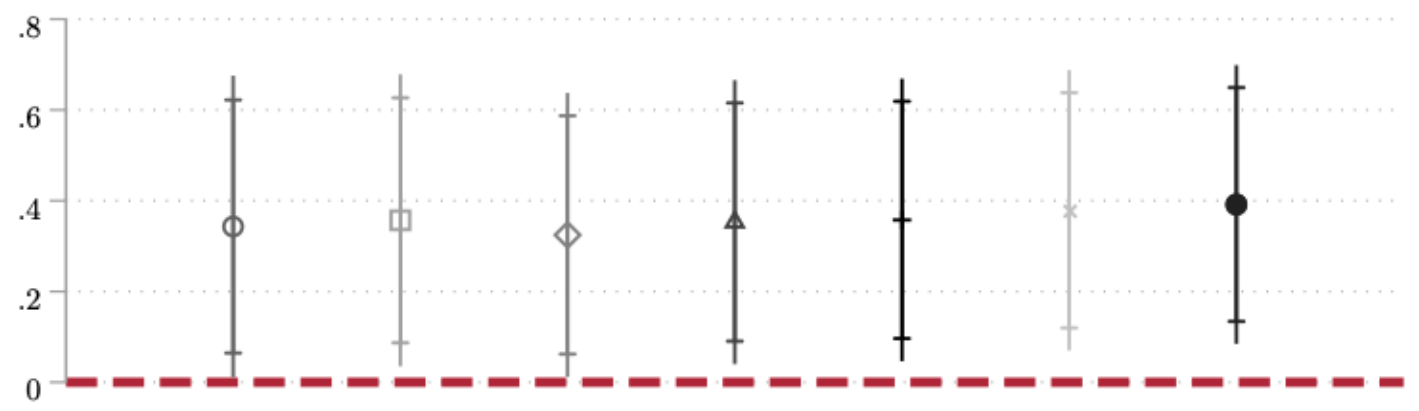

Dissatisfaction with democracy

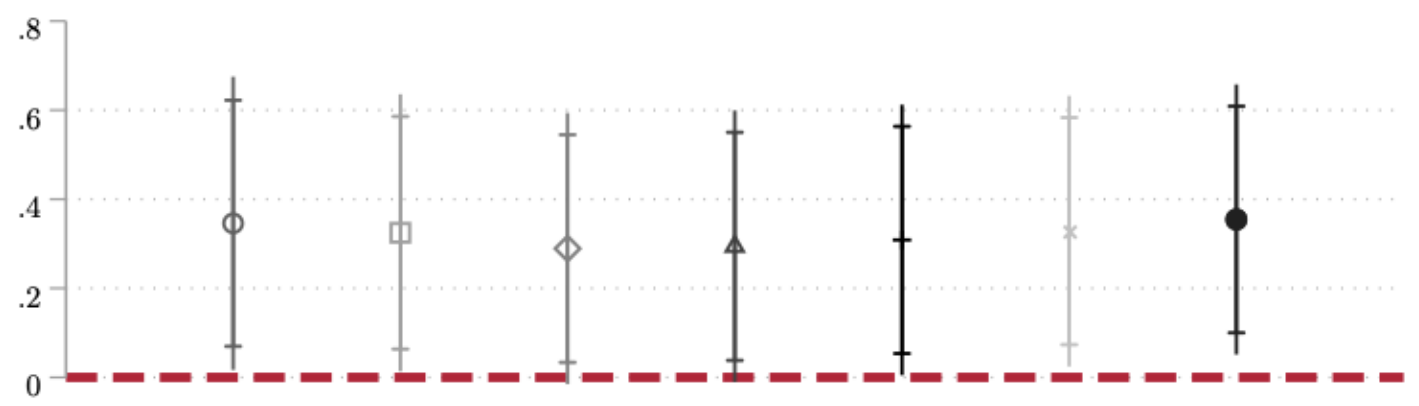

Trust in legal system

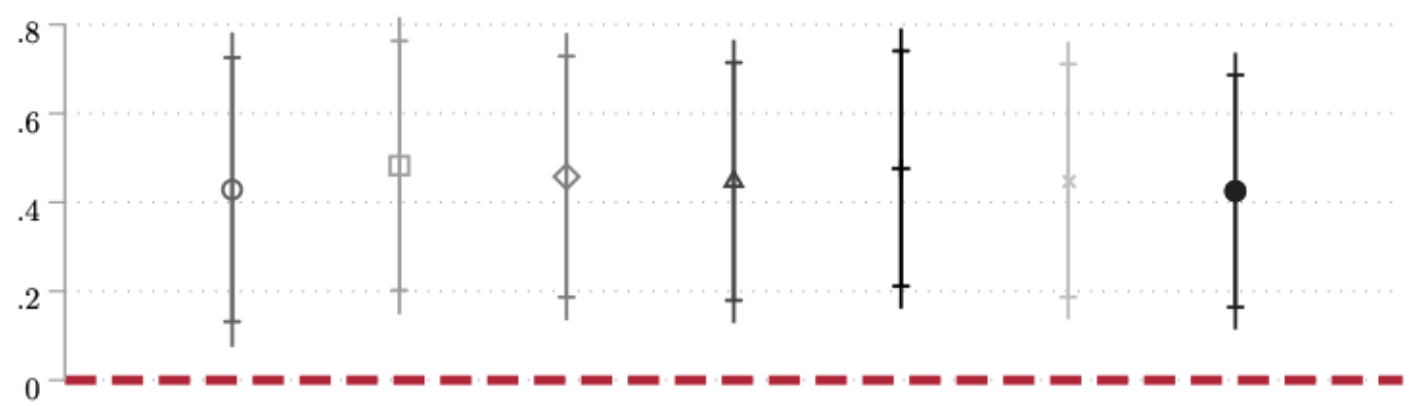

Number of matched neighbours

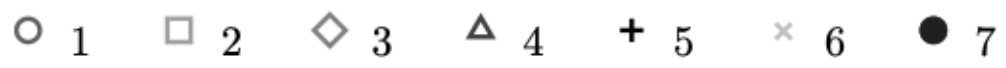

Confidence intervals at $95 \%$ and $90 \%$

Figure A9: Matching technique models 


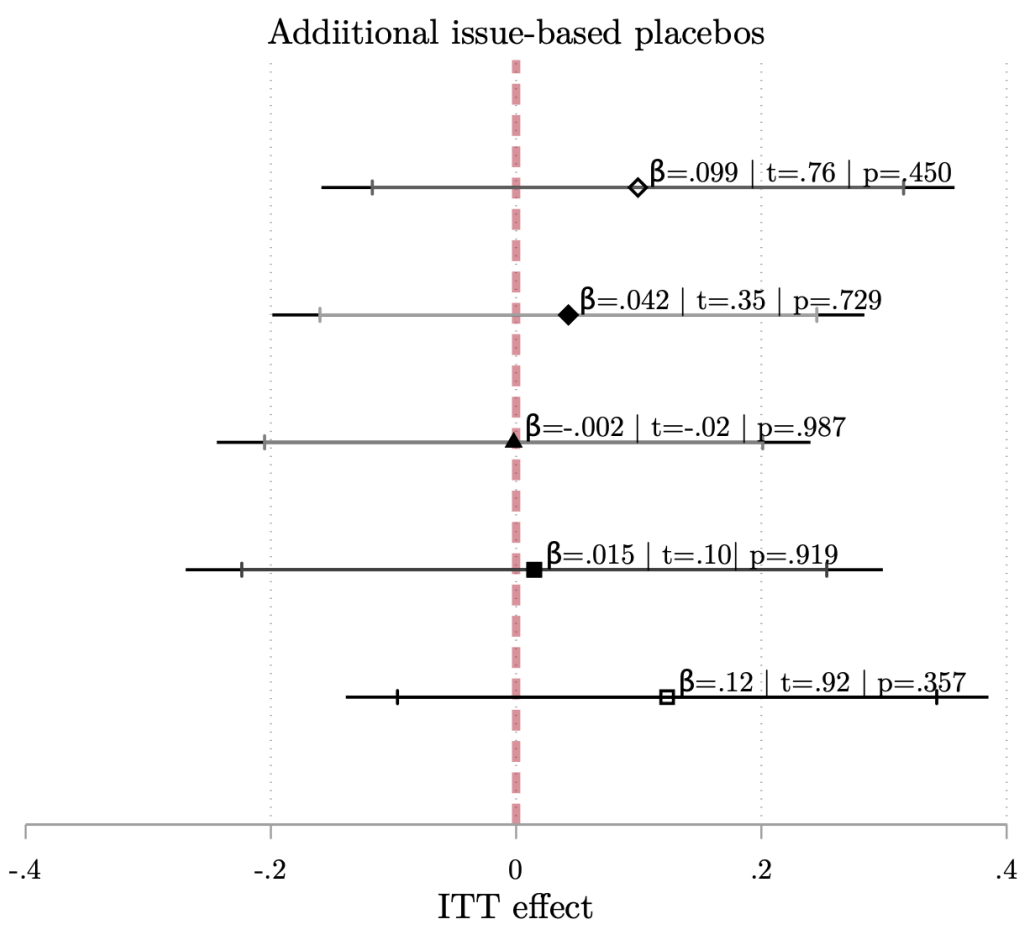

Confidence intervals at $95 \%$ and $90 \%$

Figure A10: Alternative issue-based placebos 


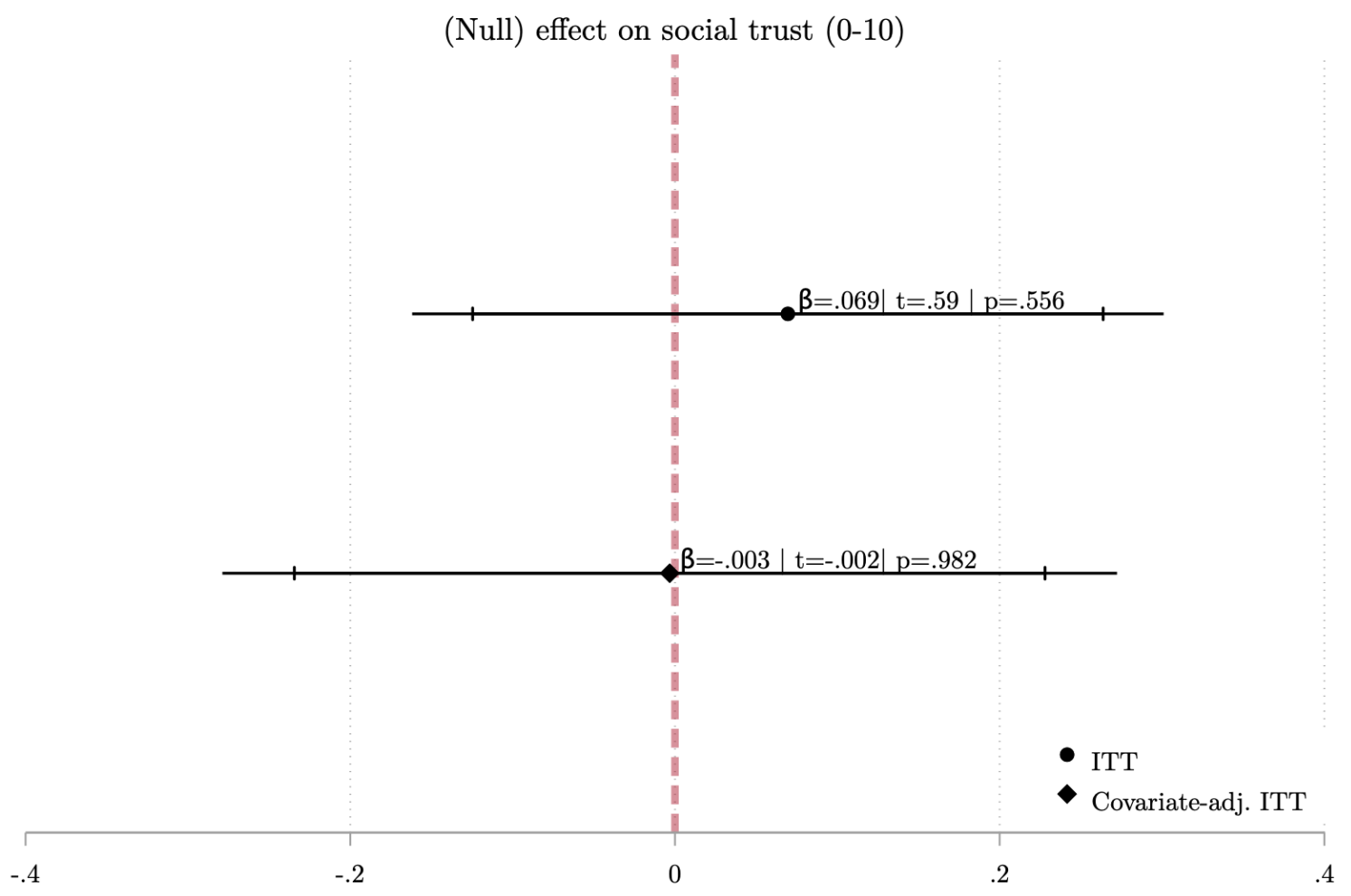

Figure A11: Null effect of treatment on general social trust

Comparison of ITT with additional covariates (CIs at 95\% \& 90\%)

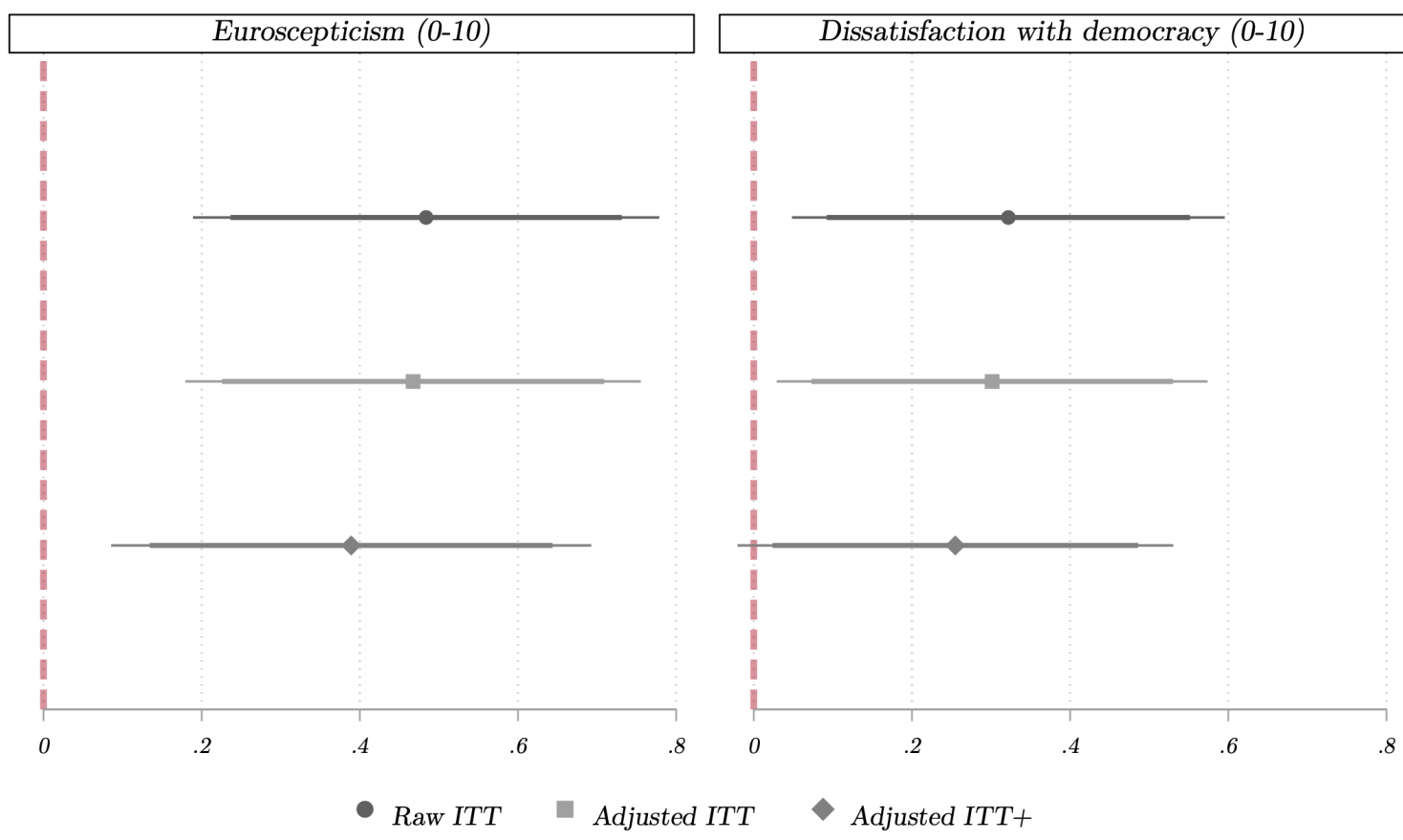

ITT+ a replication of adjusted ITT with addition of: marital status, household size, employment status, church attendance, and regional fiex effects

Figure A12: Comparison of ITT using additional covariates 


\section{Alternative modelling}

Difference in difference models

Table A8: Difference-in-Difference Model

(1)

(2)

X Euroscepticism Dissatisfaction with democracy

$\begin{array}{lcc}\text { Spain } & -1.18^{* * *} & -1.30^{* * *} \\ & (0.10) & (0.09) \\ \text { Post-treatment } & 0.10 & -0.09 \\ & (0.19) & (0.17) \\ \text { Spain*Post-treatment } & 0.36 & 0.43^{* *} \\ & (0.24) & (0.22) \\ \text { Constant } & 4.82^{* * *} & 6.41^{* * *} \\ & (0.06) & (0.05) \\ \text { Observations } & & \\ \text { R-squared } & 3,861 & 4,154 \\ \end{array}$

Robust standard errors in parentheses

${ }^{* * *} \mathrm{p}<0.01,{ }^{* *} \mathrm{p}<0.05,{ }^{*} \mathrm{p}<0.1$ 

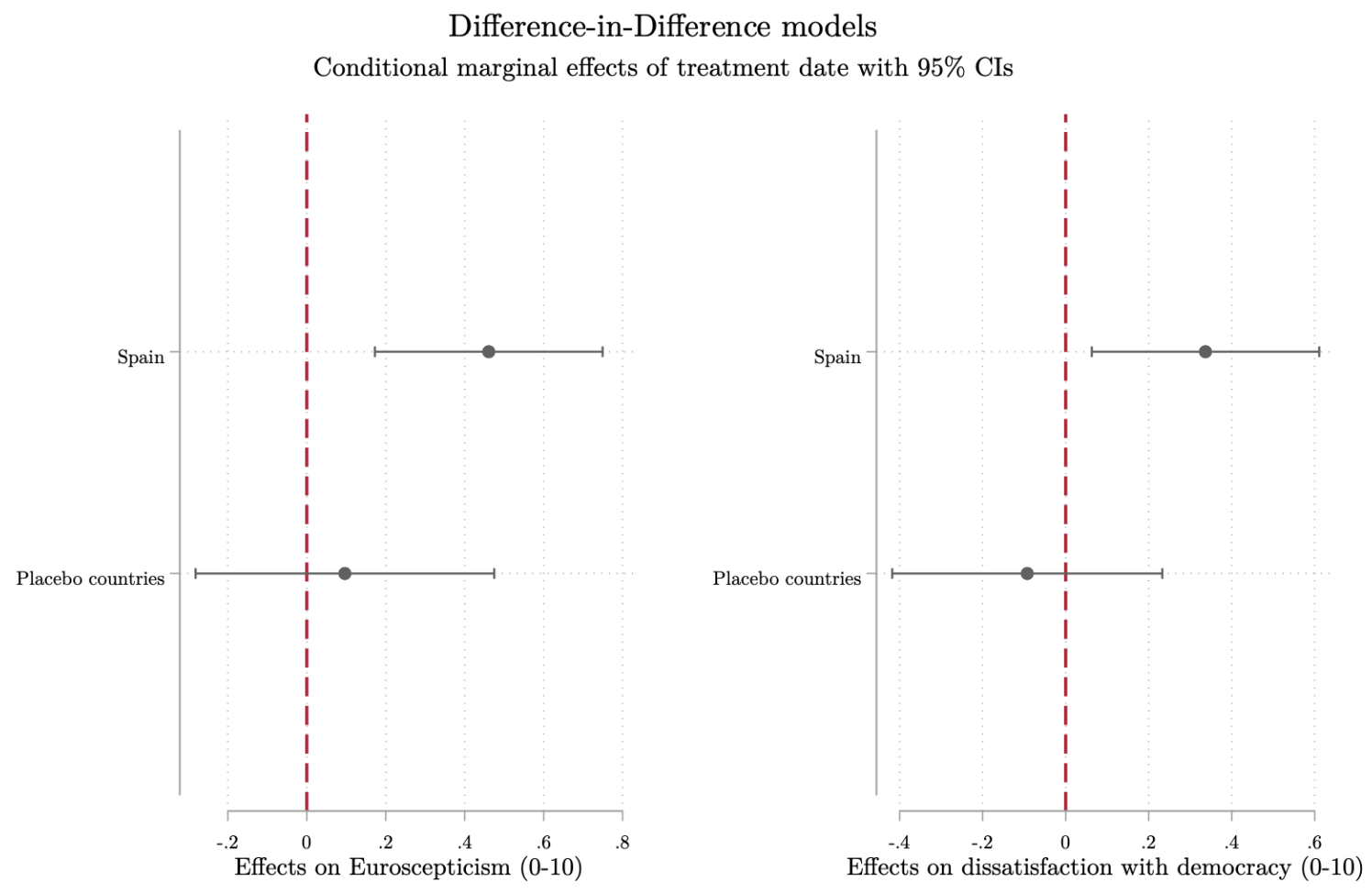

Figure A13: Diff-in-Diff: Marginal effects 


\section{Regression Discontinuity Designs (RDD)}

We conduct a range of RDD tests using the rdlocalrand package. We set the initial bandwidth to +/- 15 days. This follows a substantial precedent in setting 15 days for similar studies using the European Social Survey (Giani and Meón 2019). The window selection procedure indicates an RDD with +/- 10 days bandwidth as the optimal length, however, and these results are available in the sensitivity test figures. Our outcome variable in both cases is the binary version of euroscepticism and dissatisfaction.

With respect to the effect of the ruling on euroscepticism, the results of the RDD test with local randomisation inference indicates an insignificant $(\mathrm{p}=0.286)$ treatment effect of 0.041 ( $p=0.425$ with an effect of 0.038 for a bandwidth of 10 days). This is true for difference in means and Kolmogorov-Smirnov test statistics. The mean of the outcome before treatment is 0.174 and after is 0.214 with an effective number of observations of 236 pre-treatment and 210 post-treatment. The estimated effect of 0.041 (a change of 4 percentage-points) is a third lower than our presented ITT (6 percentage points). It is important to note that this empirical set up is extremely under-powered. The resulting power of a test to detect an effect size of 0.041 (alpha $=0.05$ ) with two groups of 230 is $7 \%$ (compared to the standard $80 \%$ power). Given this severe case of limited statistical power, it is unsurprising that the coefficient is not significantly distinguishable from zero. As discussed by Muñoz et al. (2020), application of the unexpected event approach necessities a bandwidth window that can facilitate adequate power.

We follow this with an RDD sensitivity test with results graphically presented in figure A14. We have under-laid a horizontal reference line indicating the observed RDD coefficient of 0.041 . On the $\mathrm{Y}$ axis there is a range of treatment values $[.1 ; 1]$ and the $\mathrm{X}$ axis the bandwidth range [0; 35]. Much like in the initial polynomial plots in figure A15, this indicates a null effect in the immediate aftermath of the ruling until approximately a week to 10 days after, and then a stable effect across the window lengths.

Turning to democratic (dis)satisfaction, the results of the RDD test with local ran- 


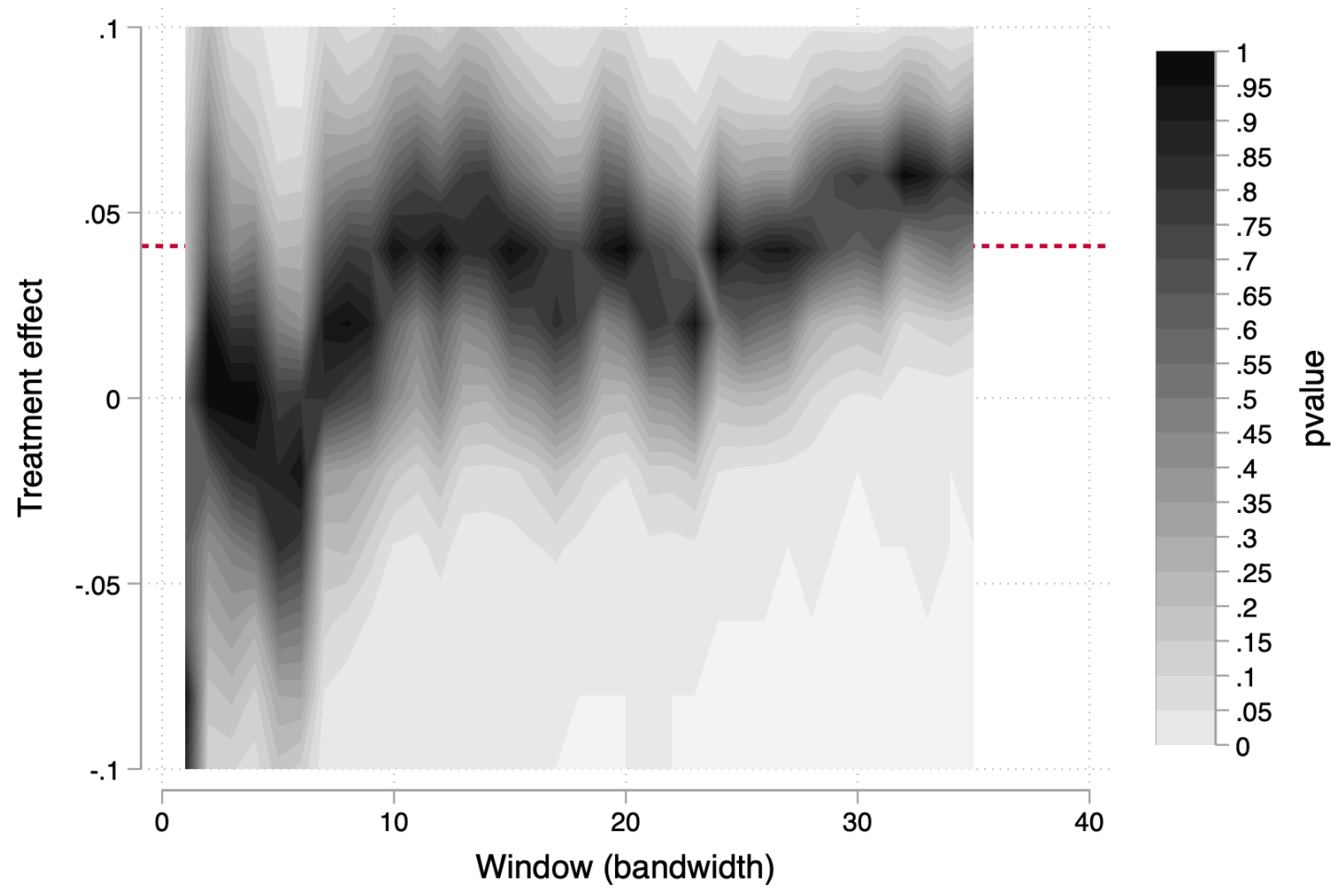

Figure A14: RDD Sensitivity tests: euroscepticism

domisation inference indicates an insignificant $(\mathrm{p}=0.734)$ treatment effect of 0.015 $(p=0.673$ on an effect of -0.022 for a bandwidth of 10 days). This is true for difference in means and Kolmogorov-Smirnov test statistics. The mean of the outcome before treatment is 0.402 and after is 0.417 with an effective number of observations of 249 pre-treatment and 223 post-treatment. The estimated effect of 0.015 (a change of 1.5 percentage points) is two thirds lower than our presented ITT (5.5 percentage points). It is important to note that this empirical set up is also extremely under-powered. The power of a test to detect an effect size of 0.015 (alpha $=0.05)$ with two groups of 230 is $5 \%$ (compared to the standard $80 \%$ power). Unsurprisingly, the empirical tests on a localised window with under such severe power restrictions produce a coefficient that cannot be identified as as distinct from zero.

As before, we follow this with an RDD sensitivity test with results graphically presented in figure A17. We have under-laid a horizontal reference line indicating the RDD coefficient of 0.015 . As in the main results and in figure A16, the results are 


\section{RDD plot: Euroscepticism}
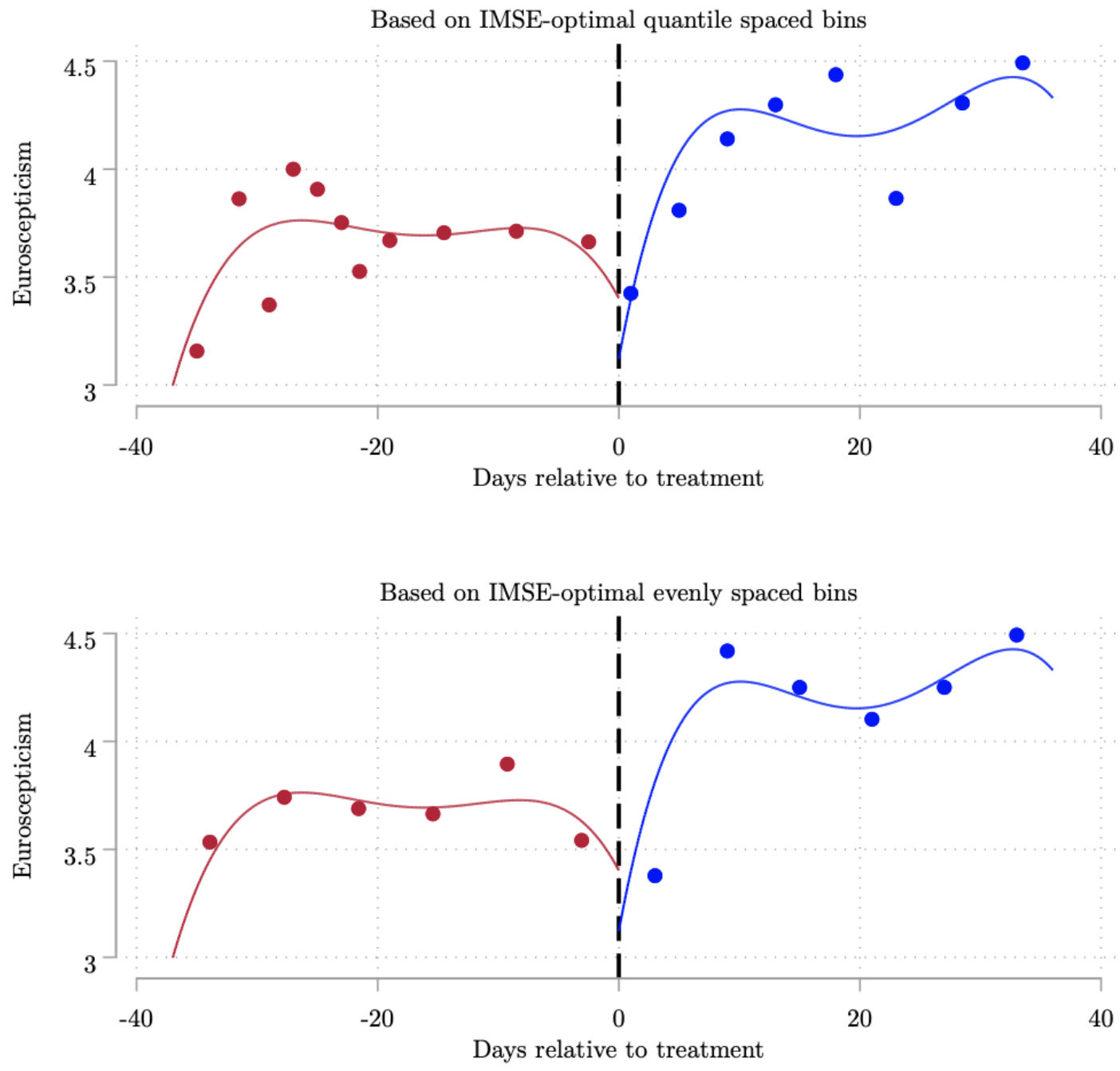

Figure A15: RDD approach: euroscepticism

weaker for this, with considerable noise. We also see the peak at the end of the window length towards greater dissatisfaction. 
RDD plot: Dissatisfaction with democracy
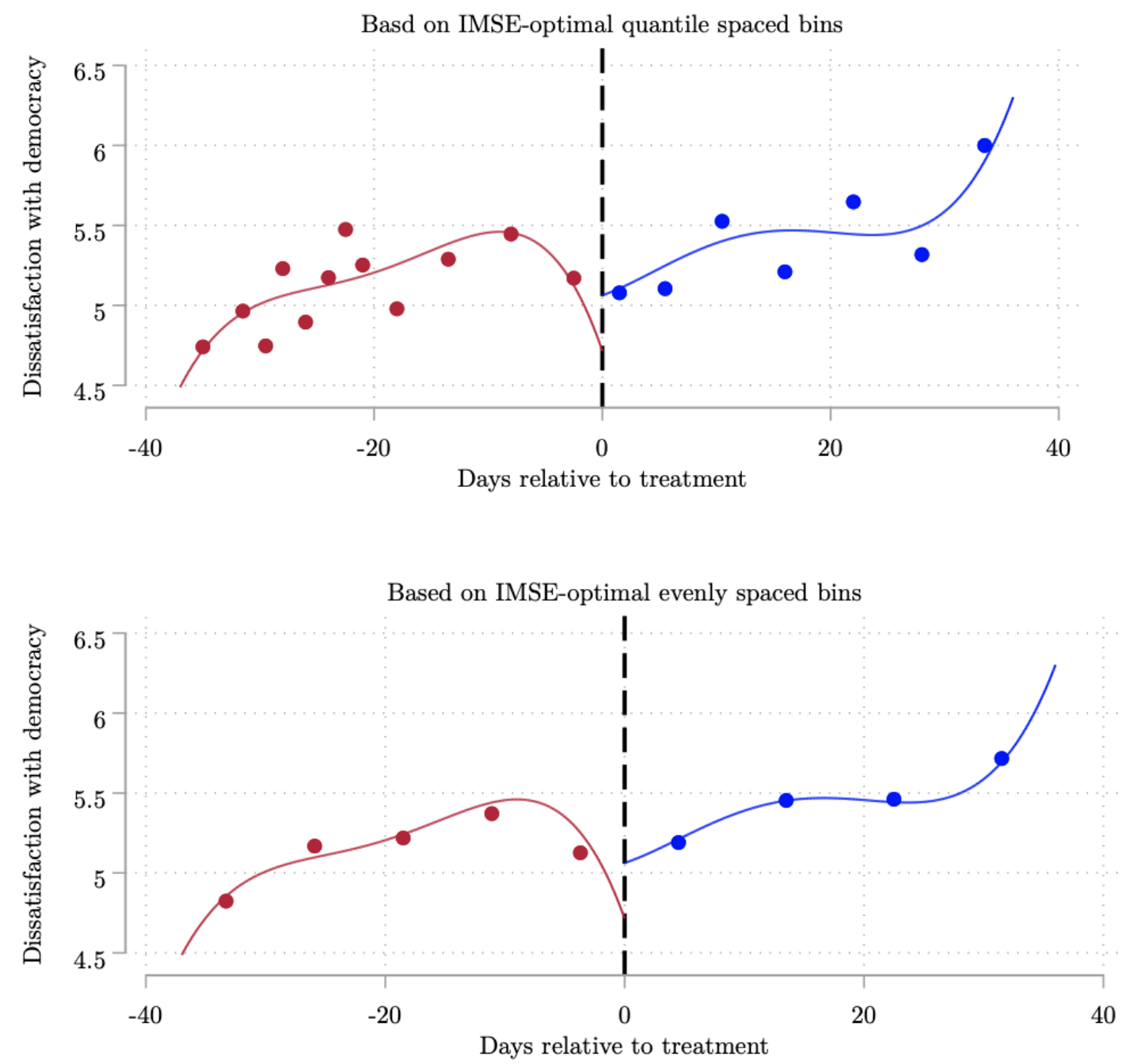

Figure A16: RDD approach: dissatisfaction with democracy 


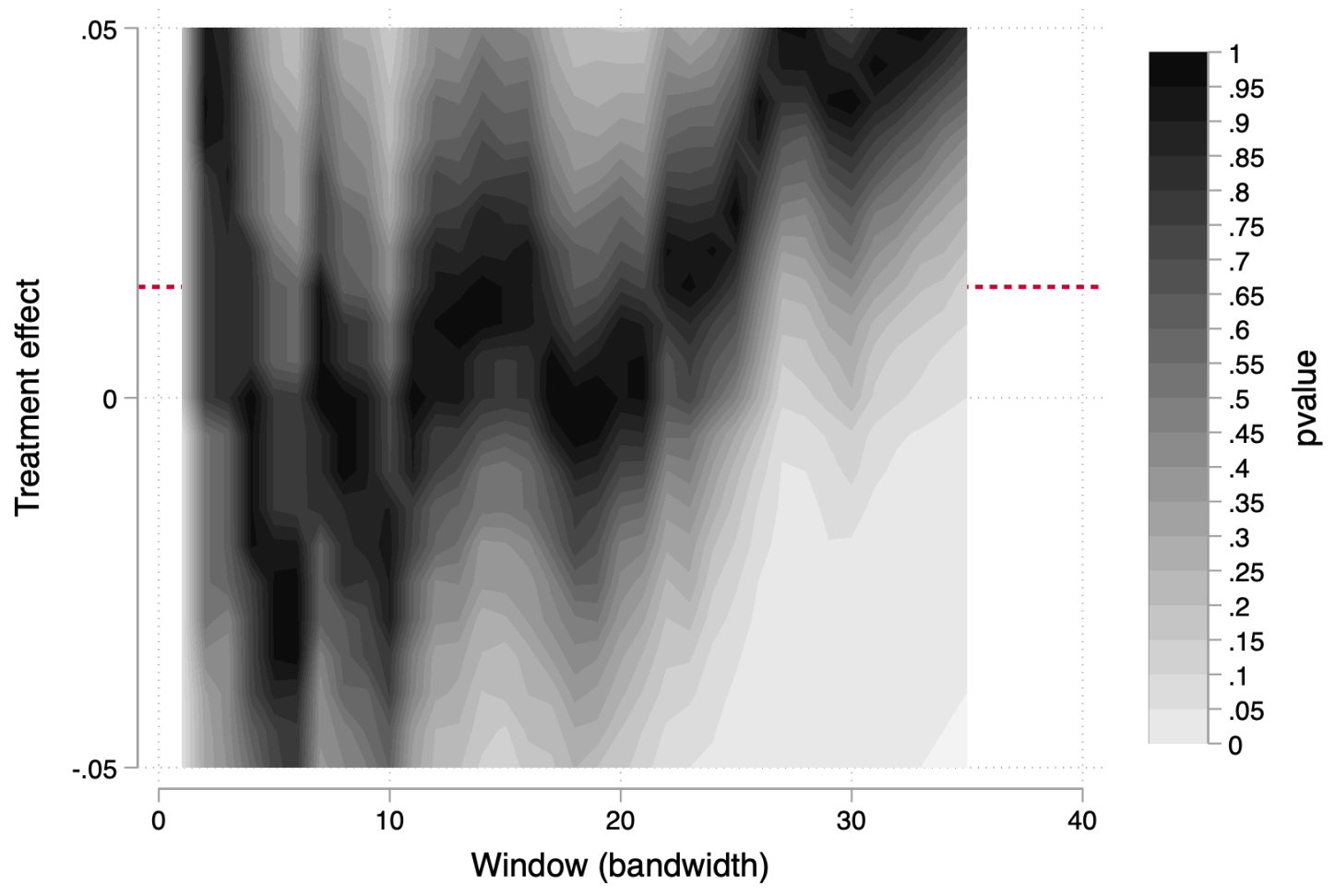

Figure A17: RDD Sensitivity tests: Dissatisfaction

Whilst it would be comforting to see an immediate effect as is assumed in the local RDD set up, many political behaviour studies display a lag between a discrete event and effects within the public. For instance, Solaz et al. (2019) argue that a corruption scandal had an impact on incumbent support but only after a week - similar to our analysis here. Indeed, Giani and Meón (2019), in their extensive supplementary material, defend adopting a two-week period when analysing the ESS and the effect of events as a reasonable trade-off between sample size and attribution of causality. Likewise, in a very different setting, Devine (2020) shows how 'Brexit' increased religious and race hate crimes in the UK but only after three days and then reached its peak 10 days after the event. Once again, this is entirely consistent with our results. That said, there are also similar studies that show an immediate effect using an RD design (Schraff 2020). We propose two reasons for this. First, it may be unsurprising considering there must be some time for events such as this to be diffused and articulated amongst the public through media, political elites, public discussion, etc. Second, there may be a more prosaic issue in that the larger the bandwidth, the larger 
the number of observations, and so the greater chance of detecting a significant effect. 
Table A9: KRLS Modelling of Euroscepticism

\begin{tabular}{llll}
\hline$X$ & Bivariate & With controls & With time \\
\hline Treatment & $0.03^{*}$ & $0.04^{*}$ & 0.015 \\
& $(0.021)$ & $(0.022)$ & $(0.018)$ \\
Time & & & $0.0006^{* *}$ \\
& & & $(0.037)$ \\
Demogs. & $\checkmark$ & $\checkmark$ \\
\hline Standard errors in parentheses \\
${ }^{* * *} \mathrm{p}<0.01,{ }^{* *} \mathrm{p}<0.05,{ }^{*} \mathrm{p}<0.1$
\end{tabular}

\section{Kernel-Based Regularized Least Squares models}

Kernel-Based Regularized Least Squares regression is a form of machine learning that allows for similar interpretations as recognisable statistical models, like OLS regressions, without imposing functional forms and attendant assumptions. This is useful in this setting for two reasons. First, we should not impose higher order, or arguably even linear terms, in the setting we have here. Second, standard regressions assume constant marginal effects, which is not what we would expect here. KRLS allows us to observe the heterogeneity of effects across the covariate space, which is a useful test to see the distribution of effects, as we will go on to demonstrate.

Our results for the KRLS estimation are in tables A9 (Euroscepticism) and A10 (dissatisfaction). Our dependent variables are the dichotomous dependent variables (presented results reported in table A5).

In the first column, we include only the treatment as a predictor. In the second, we include the controls in the same way as in the main analysis (gender, age, education, income, and left-right position). In the third, we include time. The coefficients indicate marginal effects and so are comparable to our interpretations in the main text. For Euroscepticism, the coefficients in the first two columns are significant and in the same direction as our main analyses, with an effect size approximately half that of our main analyses. On introducing time, the coefficient is positive, reduced in size, and insignificant. Time is a significant predictor. 
Table A10: KRLS Modelling of Dissatisfaction with Democracy

\begin{tabular}{llll}
\hline $\mathrm{X}$ & Bivariate & With controls & With time \\
\hline Treatment & $0.04^{*}$ & $0.06^{* *}$ & 0.002 \\
& $(0.027)$ & $(0.034)$ & $(0.04)$ \\
Time & & & $0.001^{* *}$ \\
& & $(0.000)$ \\
Demogs & $\checkmark$ & $\checkmark$ \\
\hline Standard errors in parentheses \\
*** $\mathrm{p}<0.01,{ }^{* *} \mathrm{p}<0.05,{ }^{*} \mathrm{p}<0.1$
\end{tabular}

The interpretation of the KRLS modelling of dissatisfaction in table A10 is similar. The effect size in the first two columns is similar to (and in the second, larger than) the coefficient presented in the main analyses. With the introduction of time however, the coefficient becomes trivial, and time is a significant predictor.

As Hainmueller and Hazlett (2014) and Ferwerda et al. (2017) show, these average marginal effects can be masking important variation. To get at this, we follow their recommendation and show the distribution of marginal effects of treatment on Euroscepticism and dissatisfaction without and without time; and for time with both Euroscepticism and dissatisfaction as outcome variables.

First, the marginal effects of the treatment on Euroscepticism are presented in figure A18. What this shows is that regardless of including time or not, the effects of the treatment are largely positive. The effect sizes are reduced when controlling for time, but the distribution is much the same. Our average effect with covariates but without time is 0.04 , but there is considerable heterogeneity around this, with some effects much larger and some around zero or with a negative effect. Likewise, whilst our average effect controlling for time is 0.015 , our modal effect is approximately double that (0.03).

Second, however, the results are more concerning for democratic dissatisfaction, presented in figure A19. This indeed shows that when controlling for time the distribution shifts towards an effect size of zero. Despite this, however, we also note some quite large effect sizes, with many around 0.05 and above. That said, time clearly has a 
greater effect here.

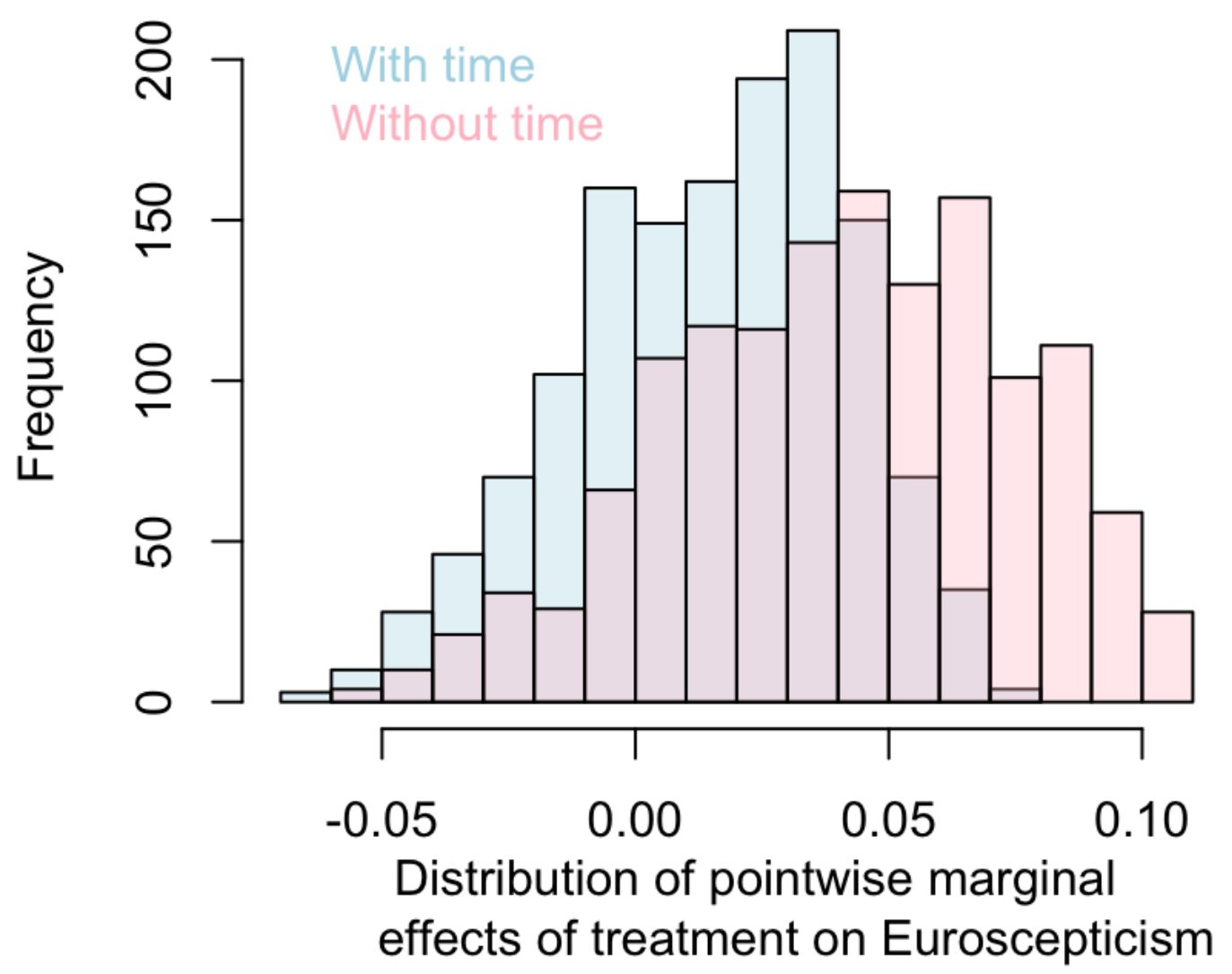

Figure A18: KRLS approach: euroscepticism

Finally, we present the marginal effect of time in figure A20. This shows the effect of time across the covariate space (from the third columns of the KRLS models). Consistent with the results so far and the previous two marginal effect distributions, the effect of time is essentially centred around zero for Euroscepticism, but has a much broader effect that is likely not zero on dissatisfaction.

Overall, our initial interpretations do not change much. Our effect sizes in this approach are much the same as in the main text analysis. We have shown that the marginal effects of the treatment variable are usually above zero with or without time, but this claim is weaker in the case of dissatisfaction. Likewise, we have shown that 


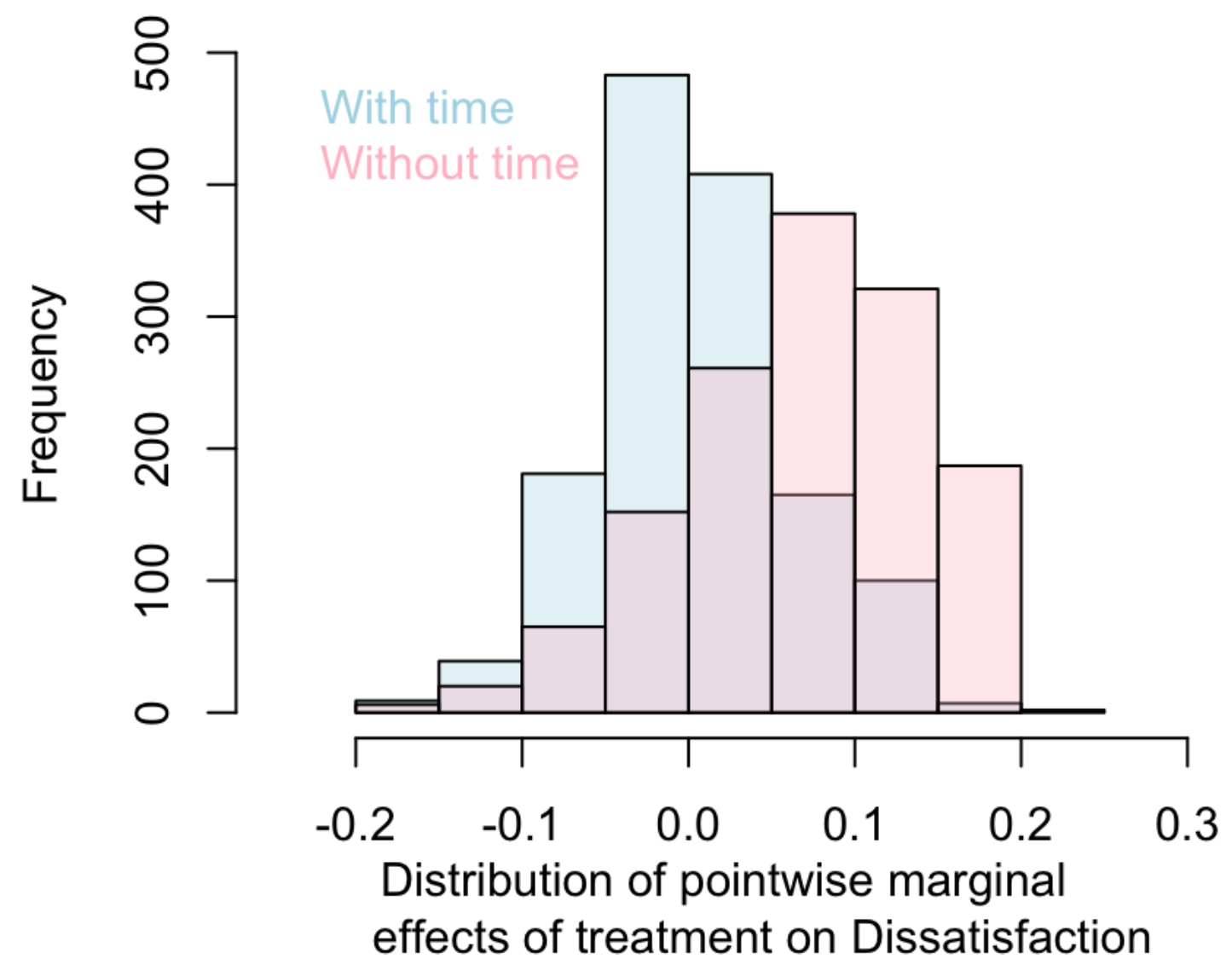

Figure A19: KRLS approach: dissatisfaction

the distribution of the marginal effects of time is centred over zero for Euroscepticism, but likely has a positive non-zero effect on dissatisfaction. 


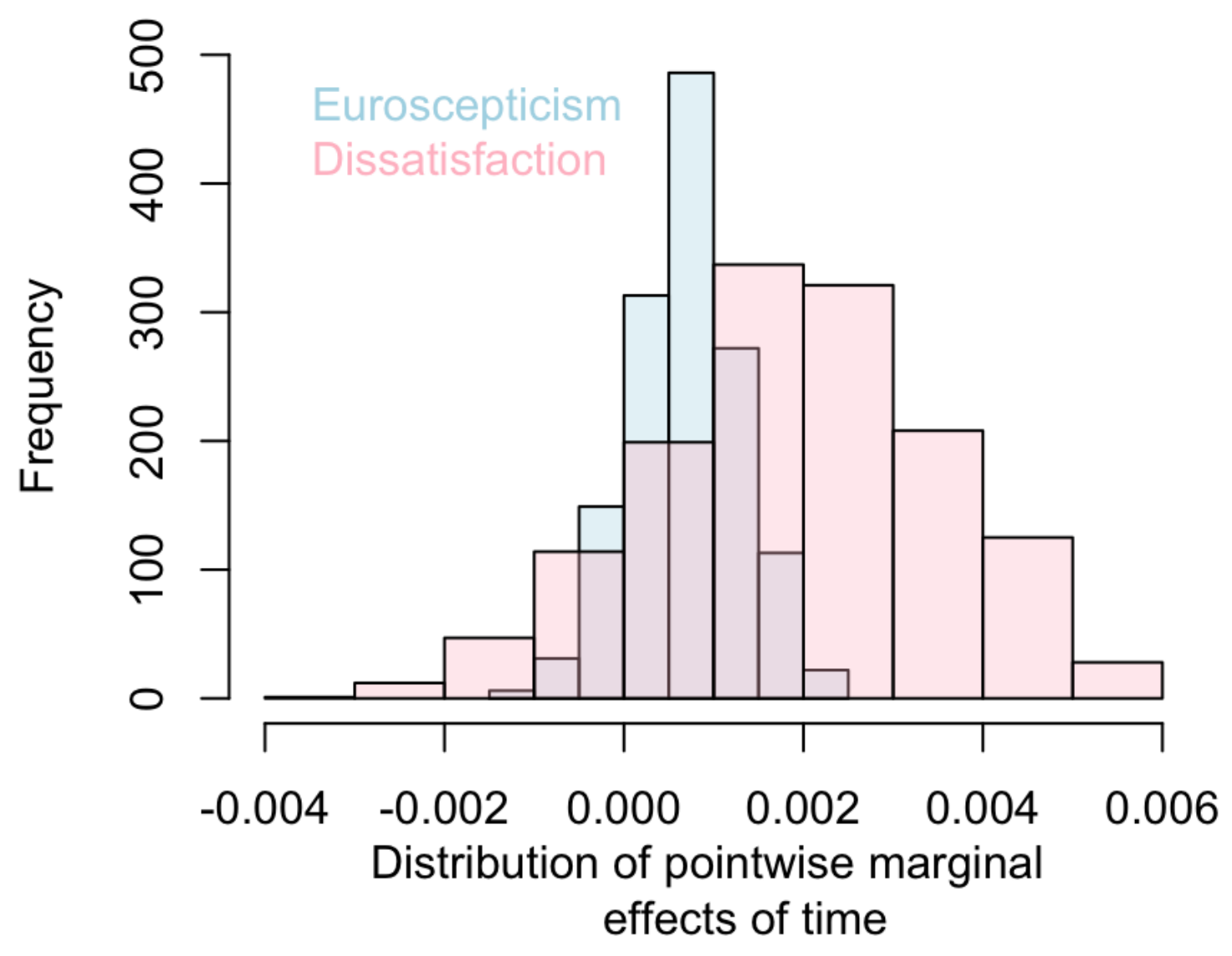

Figure A20: KRLS approach: time 


\section{Exploratory analysis of potential moderators}

Table A11: Moderating effect of region (Catalonia)

\begin{tabular}{lcc}
\hline & $(1)$ & $(2)$ \\
& Euroscepticism & Dissatisfaction w / democracy \\
Treatment & $0.54^{* * *}$ & 0.19 \\
& $(0.16)$ & $(0.15)$ \\
Region (base: all others) & & \\
Catalonia & -0.31 & $1.10^{* * *}$ \\
& $(0.24)$ & $(0.24)$ \\
Treatment*Catalonia & -0.25 & 0.51 \\
& $(0.40)$ & $(0.41)$ \\
Constant & $3.69^{* * *}$ & $4.99 * * *$ \\
& $(0.08)$ & $(0.08)$ \\
Observations & 1,481 & 1,584 \\
R-squared & 0.01 & 0.03 \\
\hline
\end{tabular}

Robust standard errors in parentheses

*** $\mathrm{p}<0.01,{ }^{* *} \mathrm{p}<0.05,{ }^{*} \mathrm{p}<0.1$ 
Effect of treatment conditioned by self-placement on the left-right axis

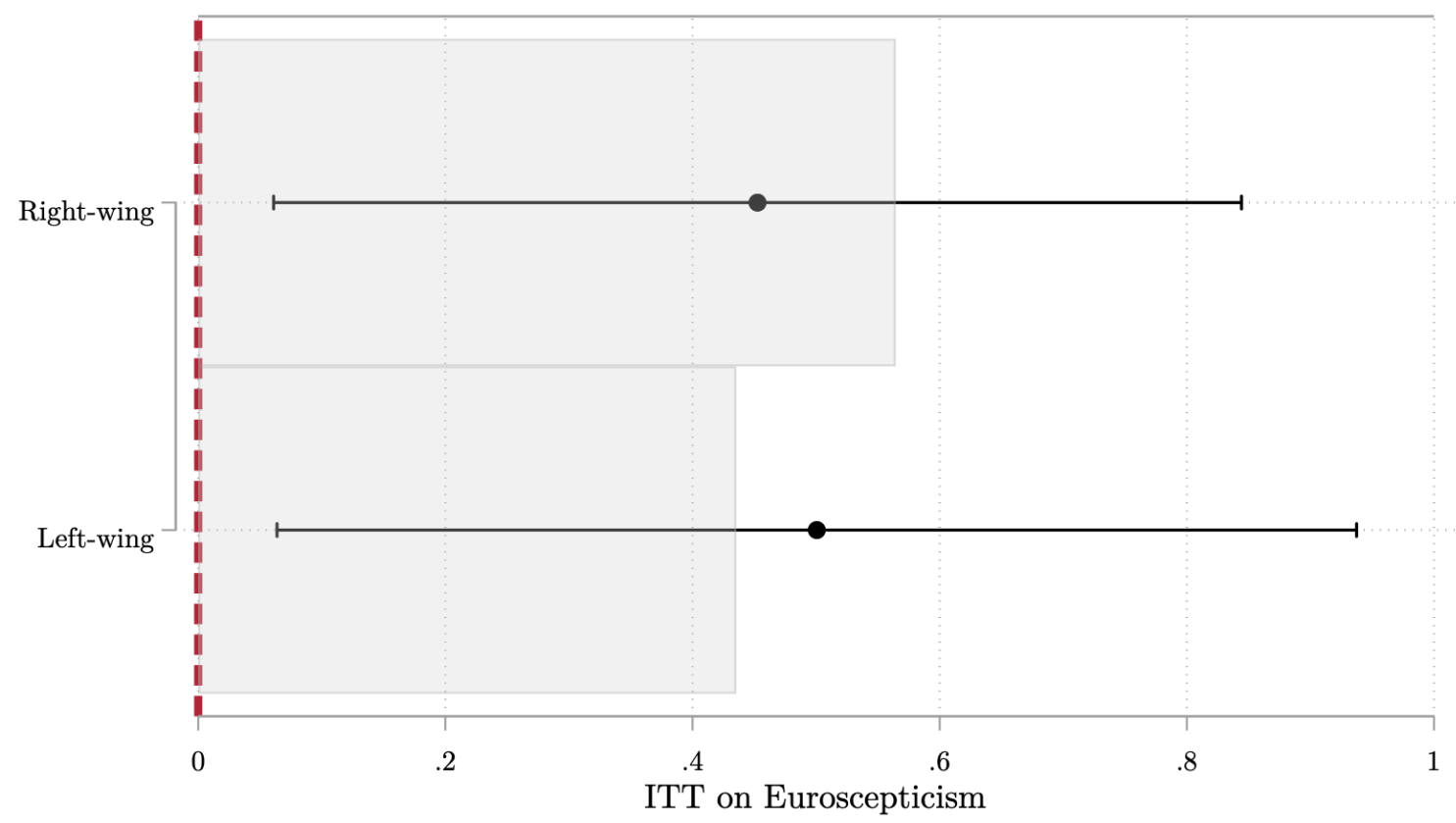

Confidence intervals at $95 \%$

Figure A21: Replication of partisan moderation using ideological placement 
Conditional marginal effects of treatment conditioned by degree status with $95 \%$ CIs
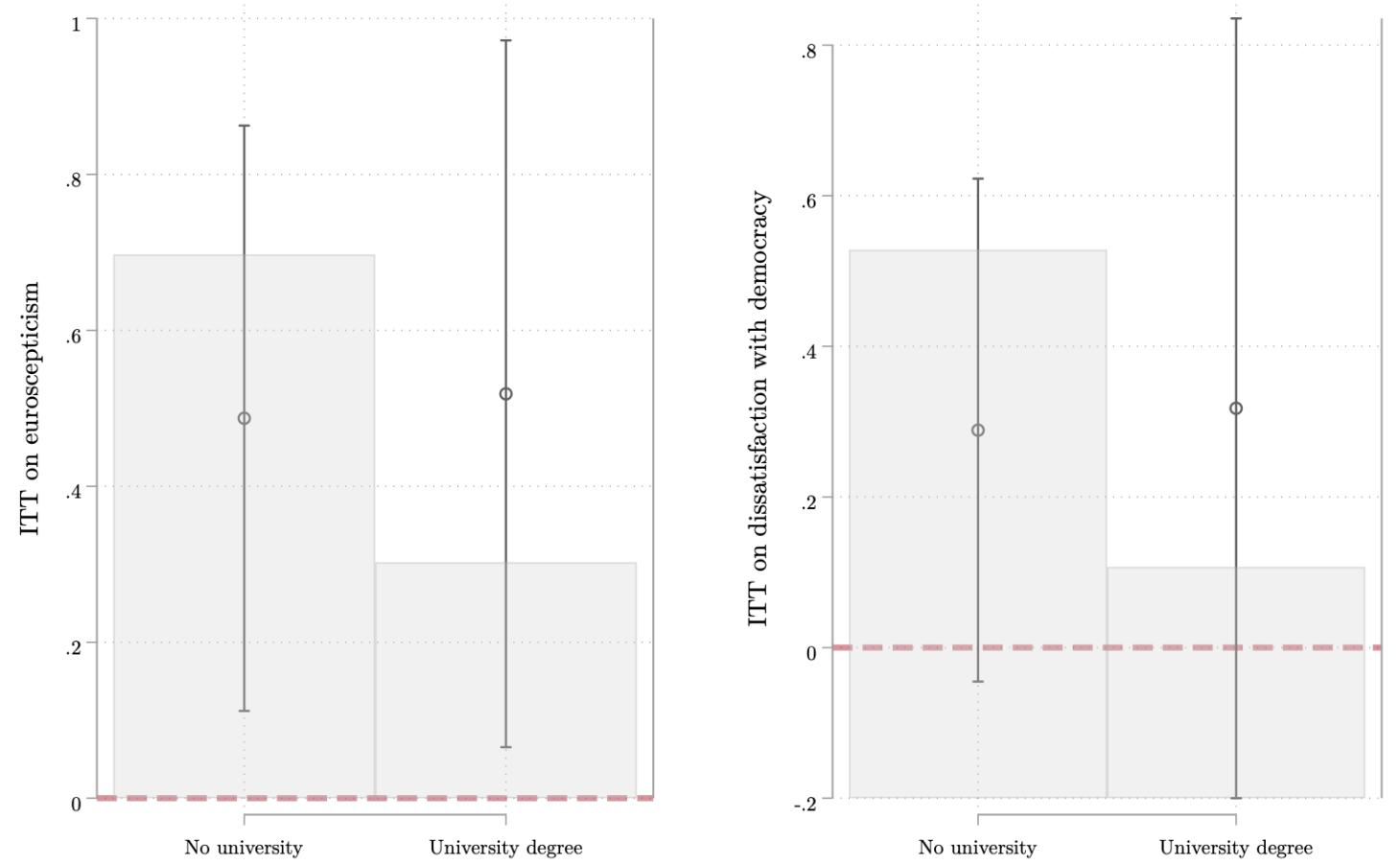

Figure A22: Moderator (i): Education

Conditional marginal effects of treatment conditioned by past turnout with $95 \%$ CIs
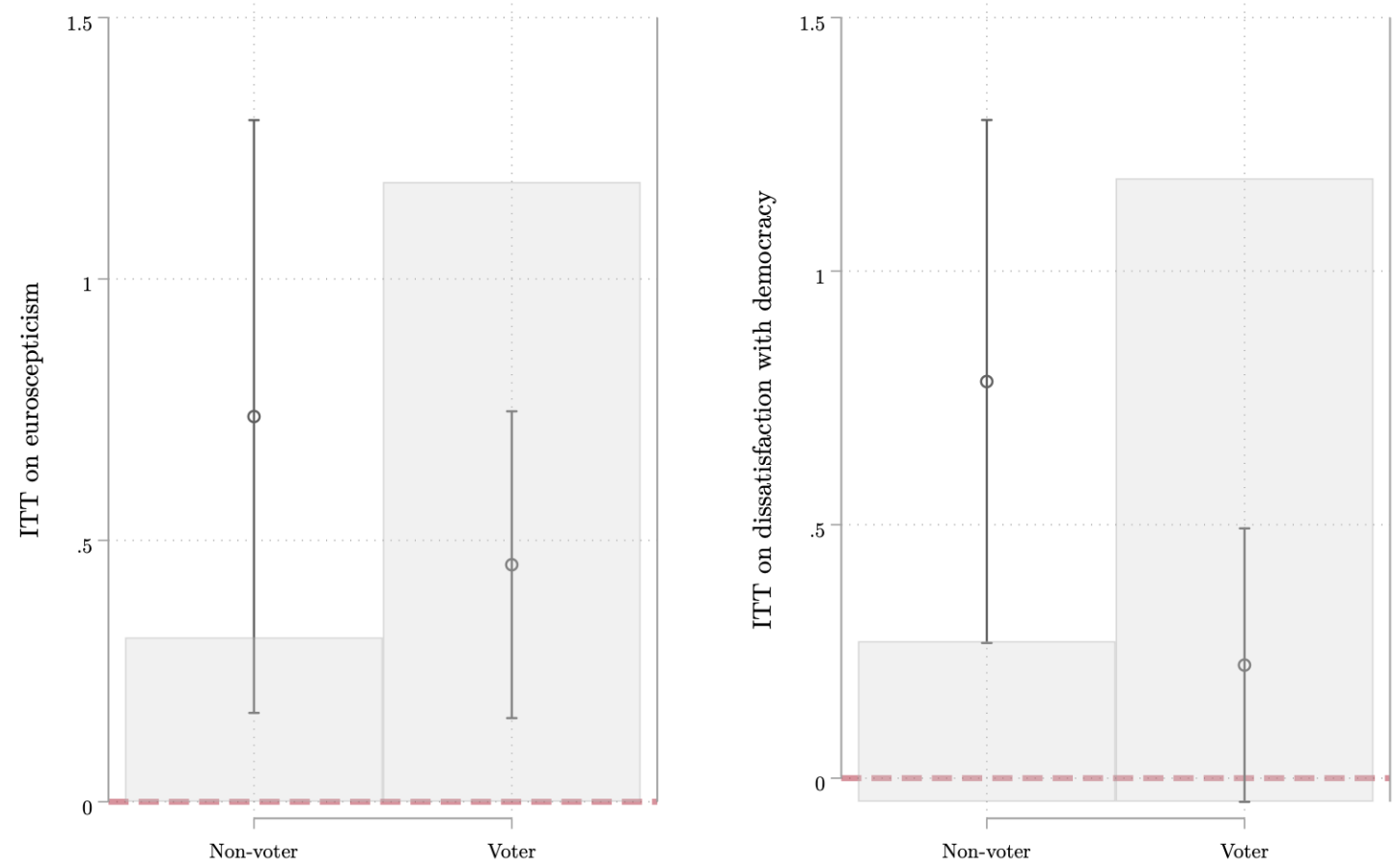

Figure A23: Moderator (ii): Voting record 
Conditional marginal effects of treatment conditioned by political interest with $95 \%$ CIs
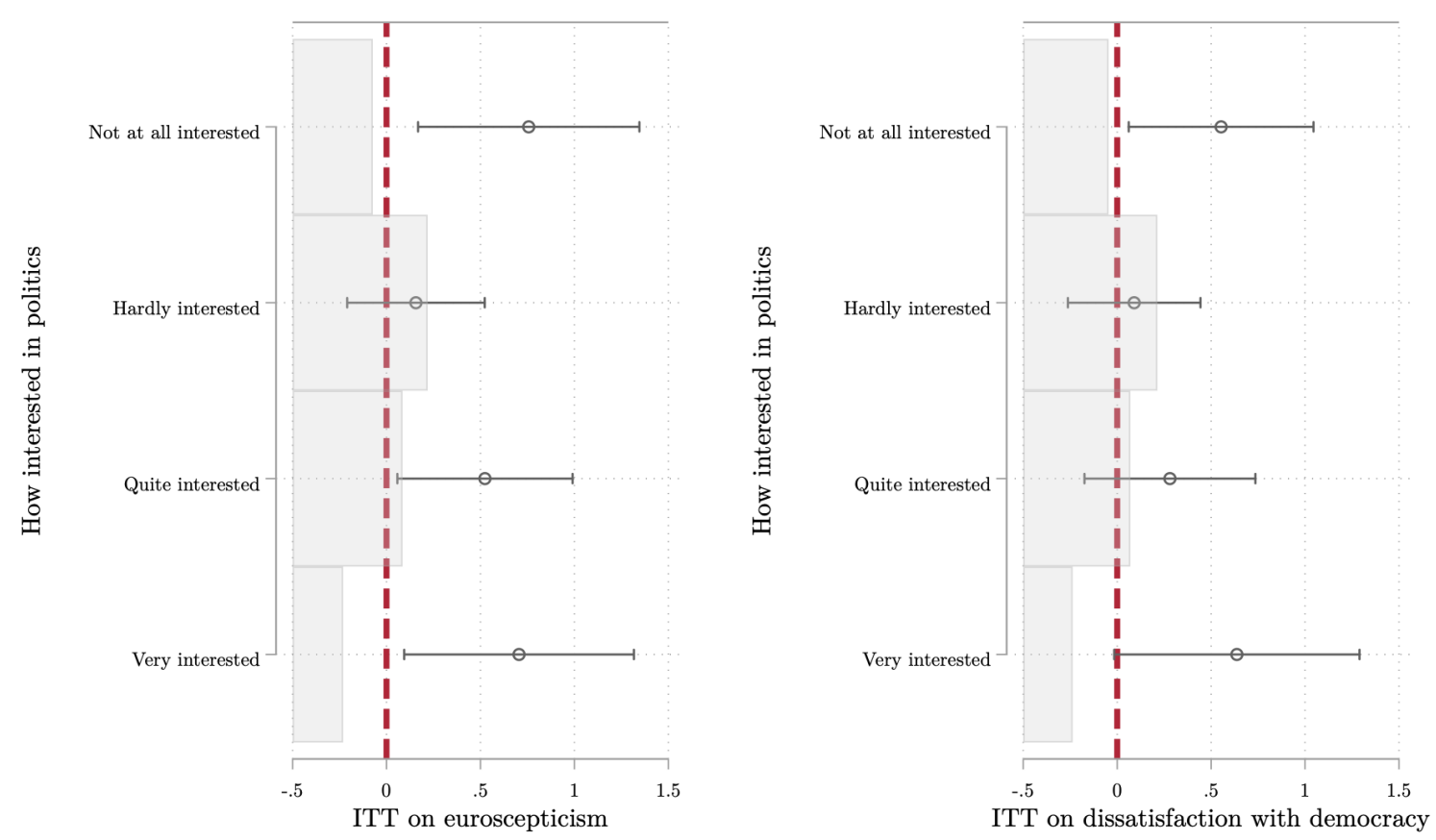

Figure A24: Moderator (iii): Political interest

\section{Time trends}




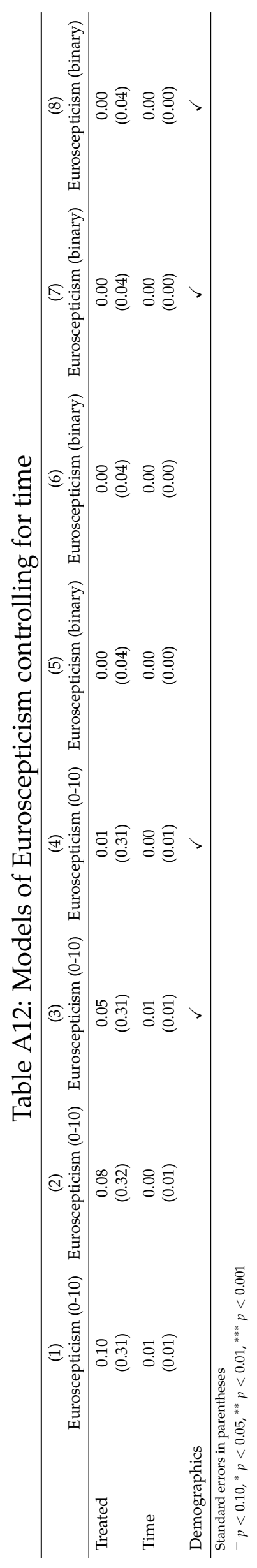


Testing pre/post time trends
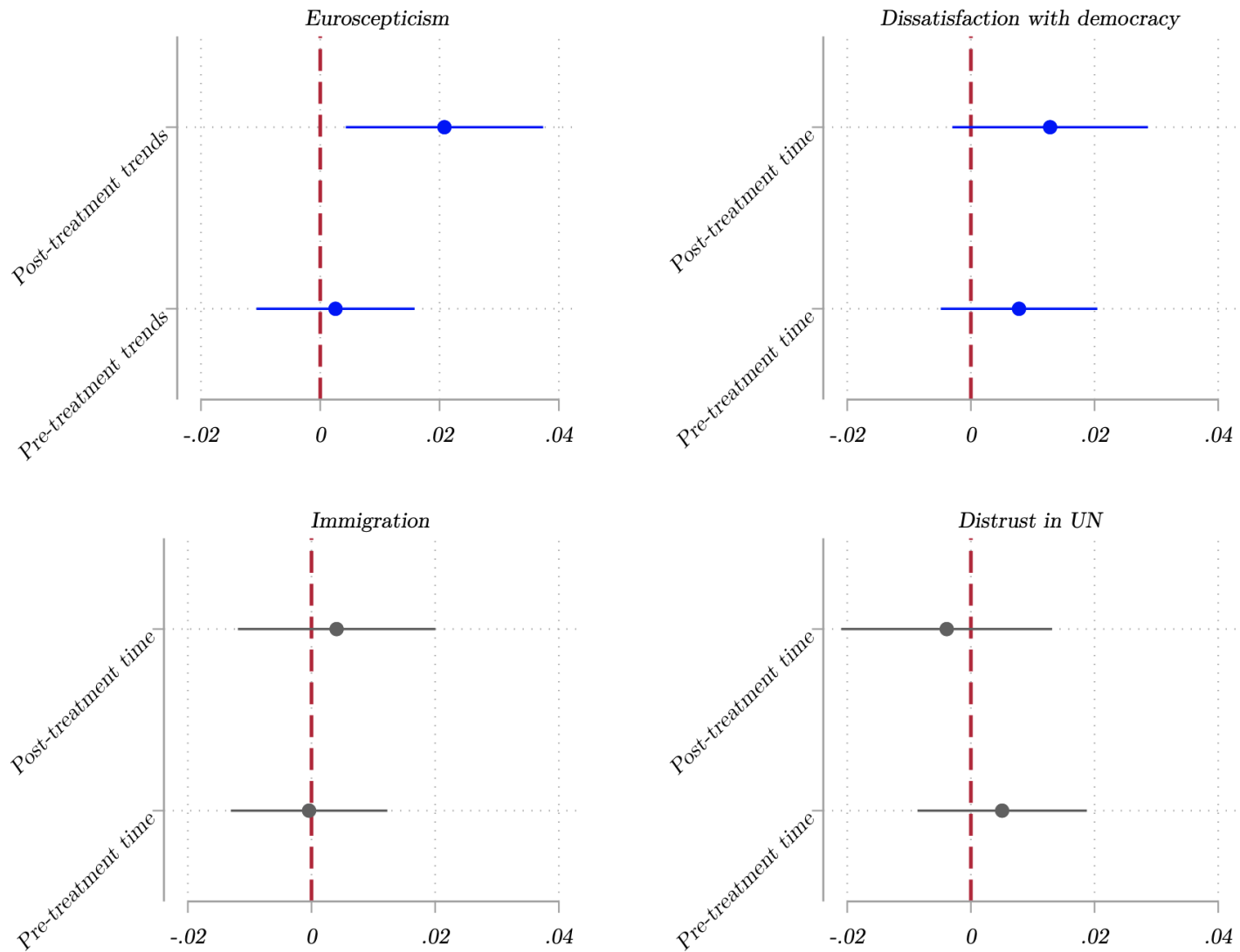

Figure A25: Time trends in main outcomes and placebos

Table A13: Models of democratic satisfaction controlling for time

\begin{tabular}{|c|c|c|c|c|c|c|c|c|}
\hline & $\begin{array}{c}(1) \\
\operatorname{SWD}(0-10)\end{array}$ & $\begin{array}{c}(2) \\
\operatorname{SWD}(0-10)\end{array}$ & $\begin{array}{c}(3) \\
\operatorname{SWD}(0-10)\end{array}$ & $\begin{array}{c}(4) \\
\operatorname{SWD}(0-10)\end{array}$ & $\begin{array}{c}\text { (5) } \\
\text { SWD (binary) }\end{array}$ & $\begin{array}{c}\text { (6) } \\
\text { SWD (binary) }\end{array}$ & $\begin{array}{c}\text { (7) } \\
\text { SWD (binary) }\end{array}$ & $\begin{array}{c}\text { (8) } \\
\text { SWD (binary) }\end{array}$ \\
\hline Treated & $\begin{array}{l}-0.30 \\
(0.29)\end{array}$ & $\begin{array}{l}-0.31 \\
(0.29)\end{array}$ & $\begin{array}{l}-0.23 \\
(0.29)\end{array}$ & $\begin{array}{c}-0.24 \\
(0.29)\end{array}$ & $\begin{array}{c}-0.04 \\
(0.05)\end{array}$ & $\begin{array}{l}-0.04 \\
(0.05)\end{array}$ & $\begin{array}{c}-0.03 \\
(0.05)\end{array}$ & $\begin{array}{l}-0.03 \\
(0.05)\end{array}$ \\
\hline Time & $\begin{array}{l}0.02^{*} \\
(0.01)\end{array}$ & $\begin{array}{c}0.01 \\
(0.01)\end{array}$ & $\begin{array}{l}0.01^{*} \\
(0.01)\end{array}$ & $\begin{array}{c}0.01 \\
(0.01)\end{array}$ & $\begin{array}{l}0.00^{*} \\
(0.00)\end{array}$ & $\begin{array}{c}0.00 \\
(0.00)\end{array}$ & $\begin{array}{l}0.00^{+} \\
(0.00)\end{array}$ & $\begin{array}{c}0.00 \\
(0.00)\end{array}$ \\
\hline Time $^{2}$ & & $\begin{array}{c}0.00 \\
(0.00)\end{array}$ & & $\begin{array}{c}0.00 \\
(0.00)\end{array}$ & & $\begin{array}{c}-0.00 \\
(0.00)\end{array}$ & & $\begin{array}{c}-0.00 \\
(0.00)\end{array}$ \\
\hline Demographics & & & $\checkmark$ & $\checkmark$ & & & $\checkmark$ & $\checkmark$ \\
\hline
\end{tabular}

Standard errors in parentheses

$+p<0.10,{ }^{*} p<0.05,{ }^{* *} p<0.01,{ }^{* * *} p<0.001$ 
Newspaper covers 


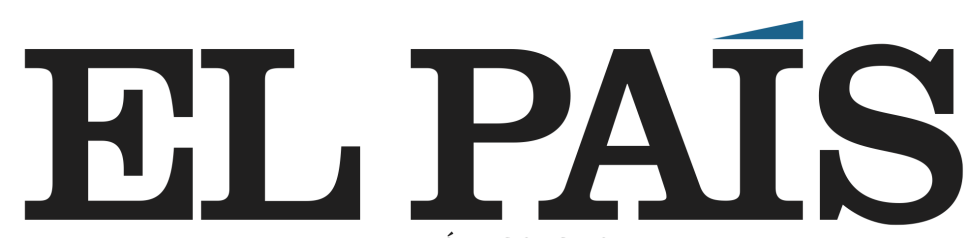

www.elpais.com

EL PERIÓDICO GLOBAL

VIERNES 20 DE DICIEMBRE DE 2019| Año XLIV | Número 15.499 | EDICIÓN MADRID | Precio: 1,70 euros

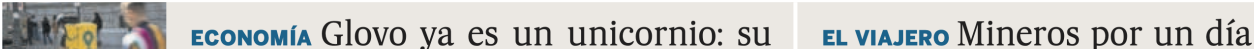
[ठ] 1 valoración alcanza 1.000 millones ${ }^{\text {p42 }}$ en las cuencas asturianas

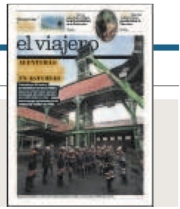

\section{La justicia europea reconoce la inmunidad de Junqueras}

El Tribunal de la UE concluye que adquirió la condición de eurodiputado tras la elección

ERC congela la investidura

hasta que la Abogacía del Estado se pronuncie
La Eurocámara levanta el veto a la entrada para Puigdemont y Comín
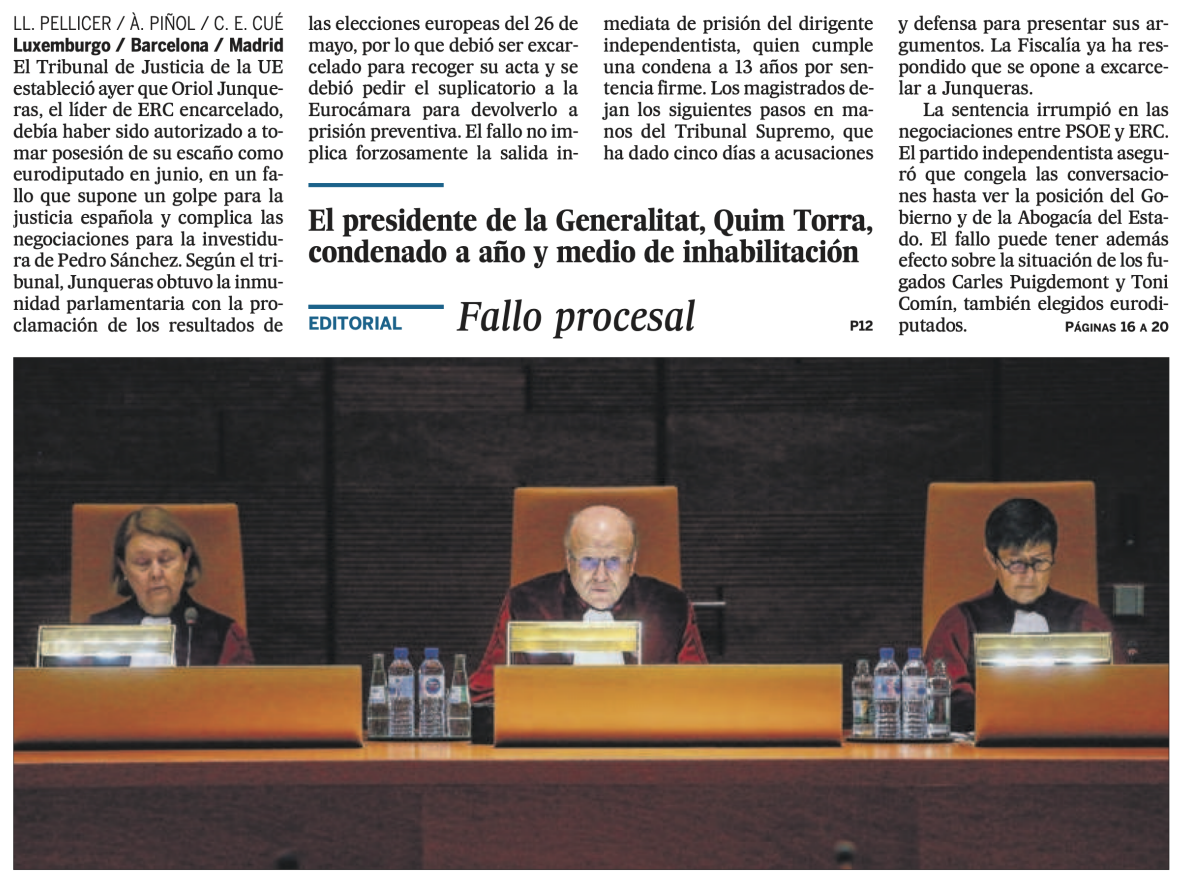

Los jueces del Tribunal de Justicia de la UE, durante la lectura pública del fallo ayer, en Luxemburgo. / JULEN WARNAND (EPA)

\section{Las familias jóvenes, lejos de recuperar la renta previa a la crisis}

ANTONIO MAQUEDA, Madrid Desde la crisis que azotó España, friendo un desplome de sus ingresos tan brutal como los jóvenes, según datos de la encuesta financiera de las familias, de Banco de Espana. Los hogare de 35 años aún tenían en 2016 una renta un $18 \%$ más baja que la de las familias de esa edad en 2010. Esto se produce a pesar de que el total de rentas antes de impuestos ya había recuperado los hogares de pensionistas han aumentado sus rentas, porque prestaciones más altas. Paciva los hogares de pensionistas han

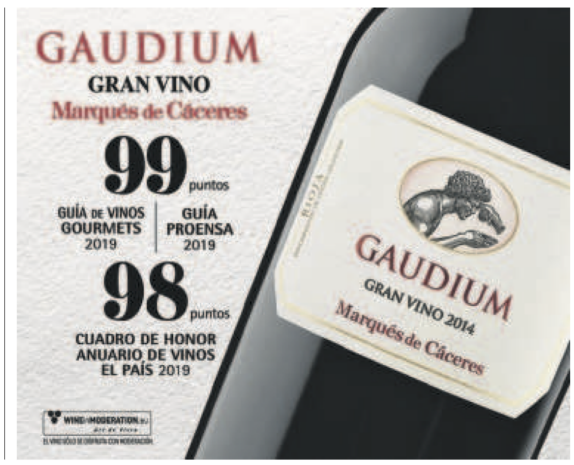

Los demócratas tratarán de asegurar un 'impeachment' con garantías

AMANDA MARS, Washington El impeachment contra Donald Trump, aprobado por la Cámara de Representantes, comienza lastrado por el partidismo. Los demócratas quieren evitar un final rápdo en el Senado, donde los republicanos cierran filas con su presidente. La líder de la Cámara, Nancy Pelosi, advirtió ayer de que no enviará al Senado los cargos mientras no se hayan sentado las base de un proceso justo", lo que poEDITORIAL EN LA PAGINA 12

Putin defiende a Trump ante las acusaciones "fabricadas"

Miles de indios desafian en la calle a Modi por su ley de ciudadanía

ÁNGEL MARTíNEZ, Bombay Una masiva protesta en ciudades de la India desafió ayer la prohibición de manifestarse en la capital y en otros Estados del país. Tres personas murieron y cerca de un millar fueron detenidas en las marchas contra la ley de ciudadanía del Gobierno de Narendra Modi, criticada por discriminar
los musulmanes. Pálina 10 PÁGina 10

La tasa de mortalidad es un $38 \%$ más alta en Andalucía que en Madrid

PABLO LINDE, Madrid La brecha económica entre comunidades impacta en sus tasa de mortalidad. En Andalucía la tasa de mortalidad es un $38 \%$ más elevada que la de Madric. Son los dos extremos, según los INE Las patologias circulatorias y los tumores volvieron ser en 2018 las primeras causas de muerte.

Figure A26: El País front page 20th December 2019 


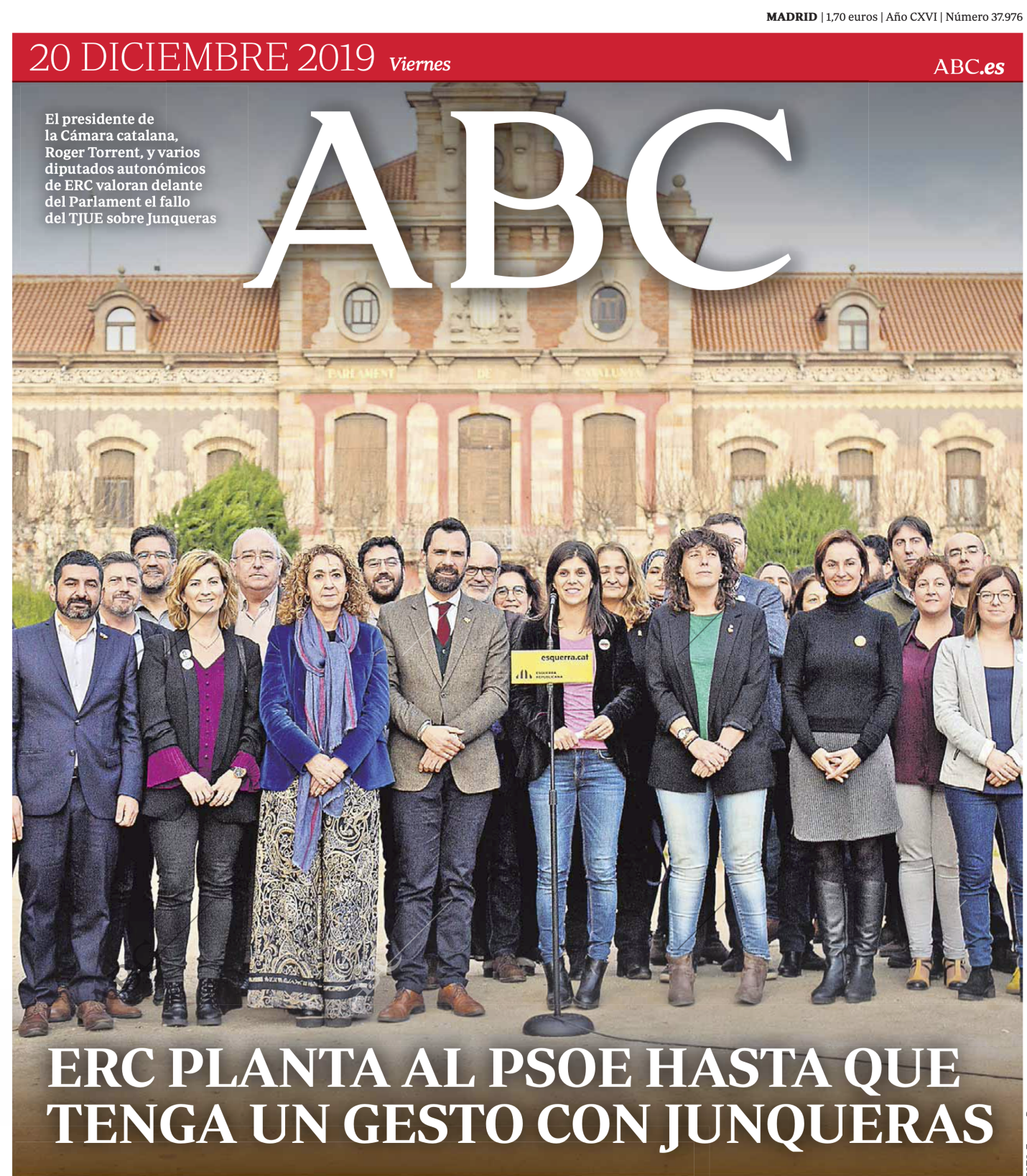

El fallo de la Justicia europea que reconoce la inmunidad del líder de Esquerra como eurodiputado complica la investidura de Sánchez Torra podría retener unos meses la Generalitat pese a ser condenado a año y medio de inhabilitación por no retirar los lazos amarillos

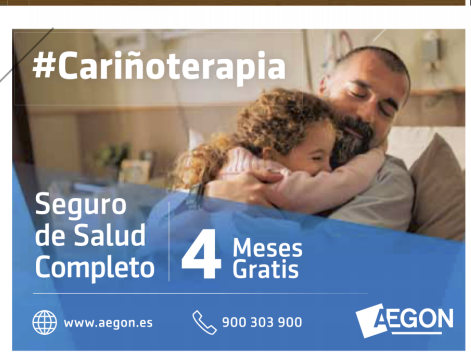

Figure A27: ABC front page 20th December 2019 


\section{Reaction to initial court decision}

On October 14th 2019, the Spanish Supreme court announced it's sentence in the Junqueras case. This announcement coincided with the fieldwork of Eurobarometer 92.2 (October 8th - October 19th 2019). In Figure A28 we assess the effect of the as good as random exposure to the court's decision on satisfaction with democracy an amongst voters who identify on the right. Right-wing voters are those most likely to support the decision given right-wing parties' stance of "being tough" on separatists.

The analysis of this quasi-experimental test demonstrates that the domestic Supreme Court decisions significantly increased support for democracy, particularly amongst those on the right.

Effect of domestic court ruling on SWD (1-4)

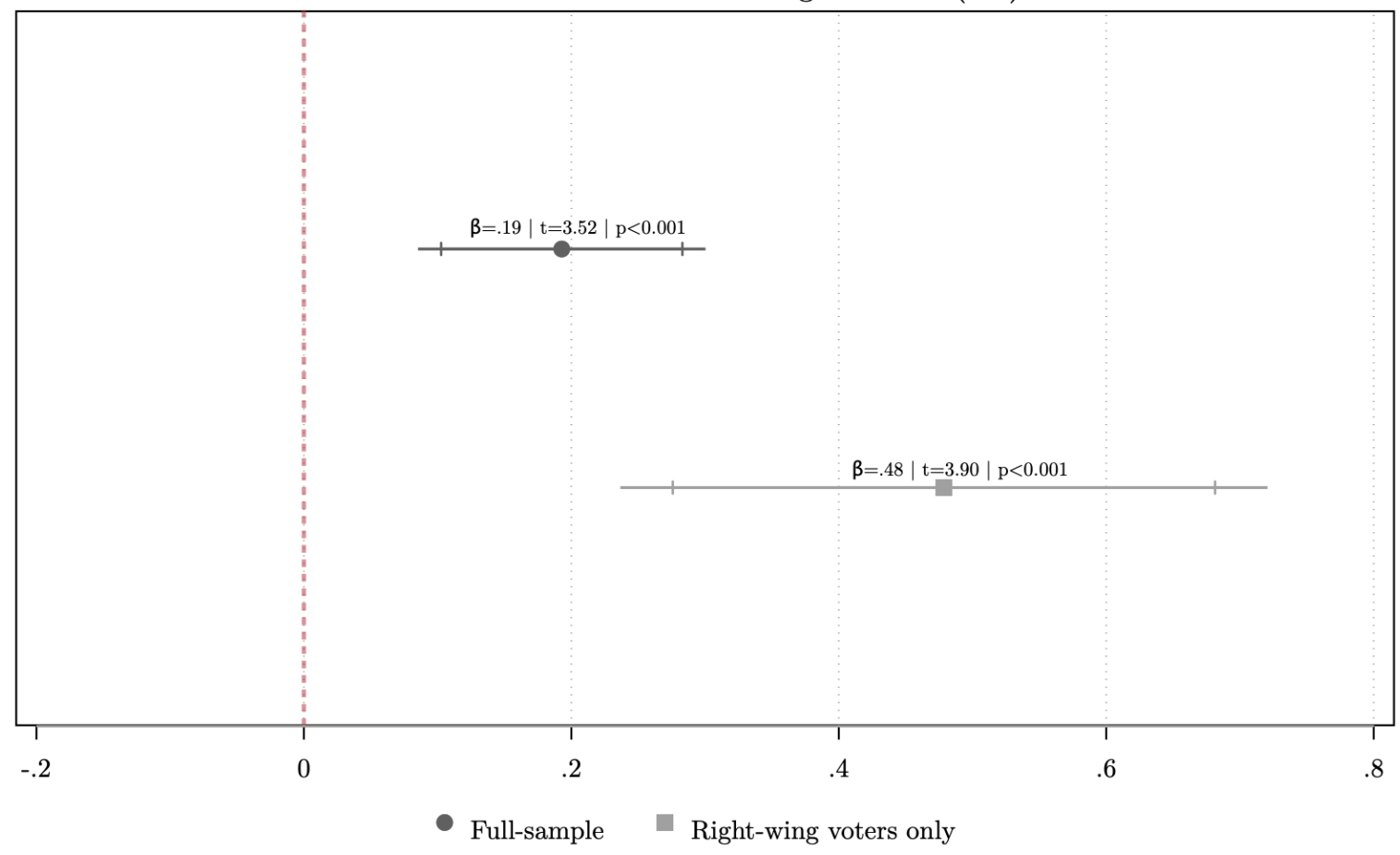

Figure A28: Domestic court effects 